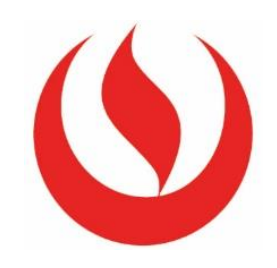

UNIVERSIDAD PERUANA DE CIENCIAS APLICADAS

FACULTAD DE ARQUITECTURA

CARRERA DE ARQUITECTURA

\title{
ESCUELA DE ARTES EXPRESIVAS EN SAN MARTÍN DE PORRES
}

TESIS

Para optar el título profesional de Arquitecto

\author{
AUTOR \\ Rayo Balandra, Bryan Alberto \\ (0000-0001-6794-0329) \\ ASESOR DE TESIS \\ Lecca Roe, Jaime \\ (0000-0002-5623-2973)
}

Lima, octubre del 2018 
Dedicado a mi familia. Gracias por ayudarme a cumplir mis objetivos como persona y estudiante. A mi padre por brindarme los recursos necesarios y estar a mi lado apoyándome y aconsejándome siempre. A mi madre por hacer de mí una mejor persona a través de sus consejos, enseñanza y amor. A mi hermano por su compañía y humor. A mi abuela por su paciencia, amor y guía que me ha brindado Todo este trabajo ha sido posible gracias a ellos. 
Agradecimiento a mi enamorada por estar conmigo en los momentos más difíciles, entenderme y confiar en mi capacidad. El resultado de mi tesis ha sido mejor de lo que me esperaba y una gran parte del desarrollo de ese trabajo te lo debo a ti, gracias Angela. 


\section{RESUMEN}

Las artes expresivas son la combinación de las artes visuales, movimiento (danza), música, escritura (poesía) y otros procesos creativos para fomentar el crecimiento personal y social. A través de estos procesos, la creatividad puede expresar el mundo interno de la persona: tanto las cosas positivas como las negativas, las fortalezas como las debilidades, las alegrías, los miedos y las tristezas. Existen organizaciones benéficas que promueven el arte como expresión corporal para un aprendizaje integro en los niños y a la vez contribuyen con el desarrollo social del lugar donde se ubican. Es así como se llega a la creación de una Escuela de Artes Expresivas en San Martín de Porres, distrito situado en Lima Norte donde ha adquirido gran notoriedad dado a su crecimiento económico.

De esta manera el proyecto de investigación ha sido desarrollado para llegar a una conclusión que satisfaga los objetivos principales: descentralizar los centros de formación y difusión de artes proponiendo un nuevo núcleo artístico en Lima Norte, promover terapias a través de actividades plásticas, corporales y musicales, dotar de una relación y organización espacial capaz de estimular nuevas situaciones y entornos para el aprendizaje de las artes.

Concluyendo que al brindar oportunidades artísticas en aficionados y profesionales, a través de las artes con un equipamiento privado y público, se incentiva un cambio cultural importante en la ciudad.

Palabras clave: Escuela/ Escuela de artes/Arte/San Martin de Porres 


\begin{abstract}
The expressive arts are the combination of the visual arts, movement (dance), music, writing (poetry) and other creative processes to promote personal and social growth. Through these processes, creativity can express the internal world of the person: positive things such as negative things, strengths such as weaknesses, joys, fears and sorrows. There are charitable organizations that promote art as a corporal expression for an integral learning in children and in the occasion with the social development of the place where they are located. This is how it comes to the creation of a School of Expressive Arts in San Martín de Porres, a district located in Lima Norte, where it has acquired great notoriety since its economic growth.

In this way the research project has been developed to reach a conclusion that satisfies the main objectives: decentralize the training centers and the dissemination of the arts proposing a new artistic core in North Lima, promote therapies through plastic, corporal activities and musical the learning system of the arts.

Concluding that providing artistic opportunities in amateurs and professionals, through the arts with a private and public equipment, an important cultural change in the city is encouraged.
\end{abstract}

Keywords: School / School of Arts / Art / San Martín de Porres. 


\section{TABLA DE CONTENIDO}

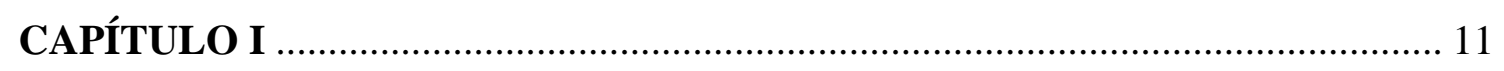

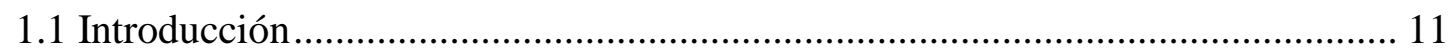

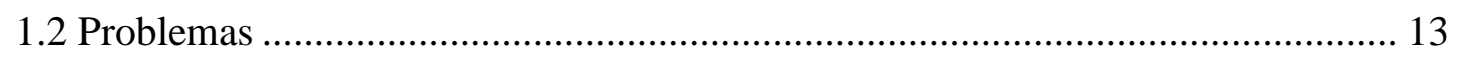

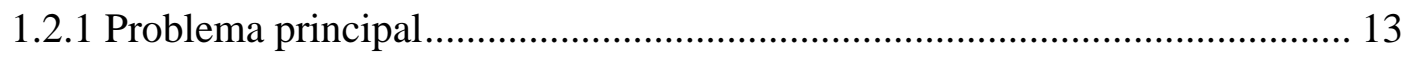

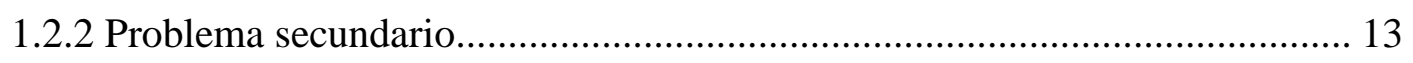

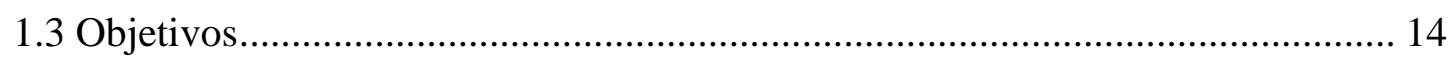

1.3.1 Objetivo principal .............................................................................. 14

1.3.2 Objetivo secundario ............................................................................. 14

CAPÍTULO II - Marco teórico / referencial ................................................................ 15

2.1 Definición de artes expresivas .......................................................................... 15

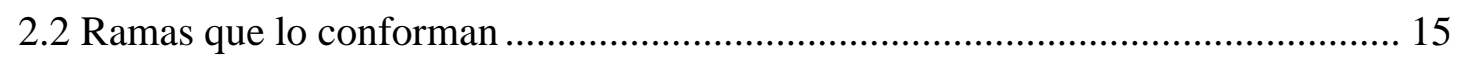

2.2.1 Terapia de Artes Expresivas (TAE)............................................................... 15

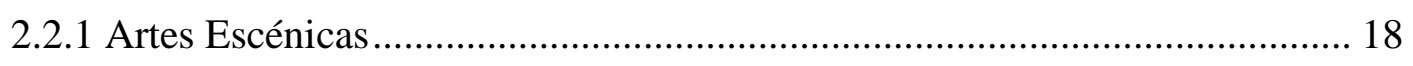

2.3 Metodología de enseñanza colaborativa para las artes ......................................... 41

2.4 Demanda de la educación artística en el Perú ..................................................... 43

2.5 Oportunidades en el campo .............................................................................. 44

2.6 Importancia de la educación artística en el Perú .................................................... 45

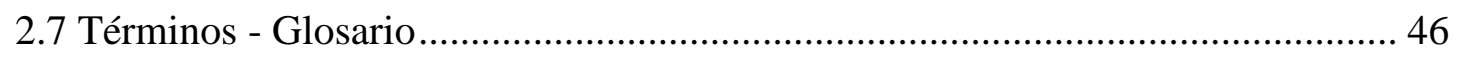

CAPÍTULO III - Marco conceptual....................................................................... 52

3.1 Énfasis: "relación y organización espacial capaz de estimular nuevas situaciones y

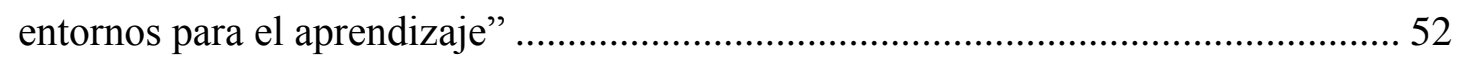

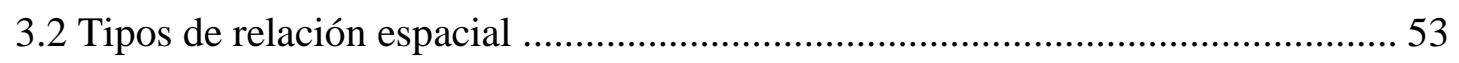

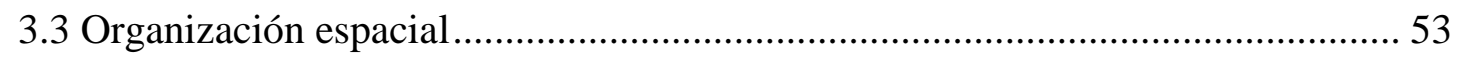

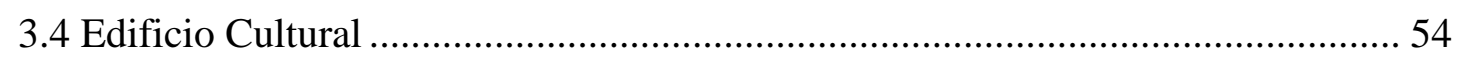

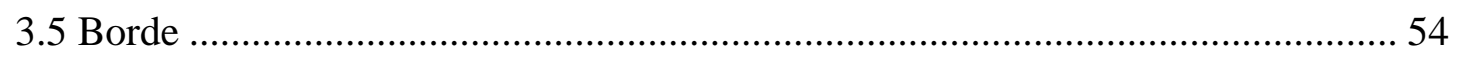

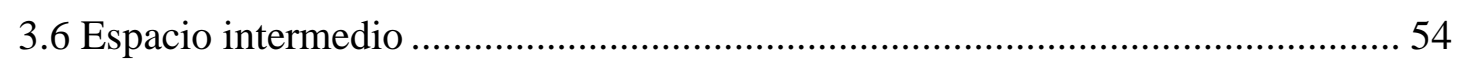

CAPÍTULO IV - Proyectos referenciales ................................................................ 55

4.1 The Julliard School, Nueva York, Estados Unidos ................................................ 55

4. 2. Escuela de diseño de la Univ. De Melbourne, Melbourne VIC, Australia.......... 55

4. 3. Centro Universitario "des Quais", Lyon, Francia ............................................... 55

4. 4. Museo de la memoria y de los derechos humanos, Santiago de Chile, Chile .... 55 
4.5. Escuela de Diseño e Instituto de Estudios Urbanos Pontificia Universidad Católica

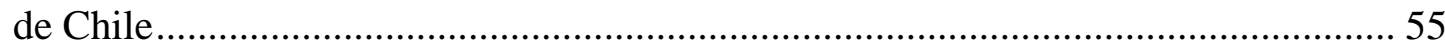

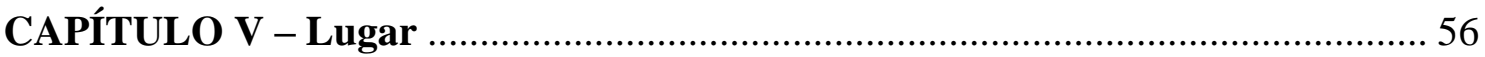

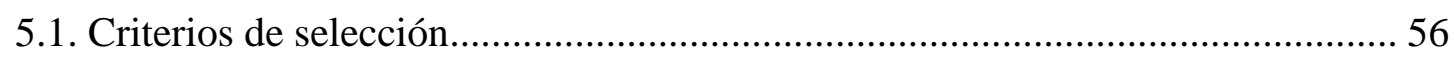

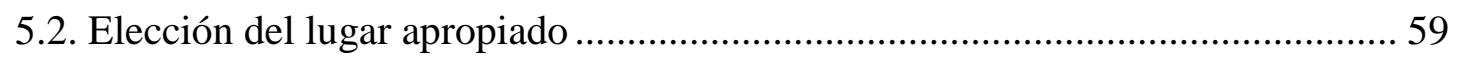

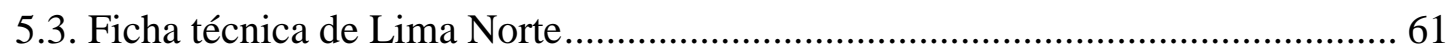

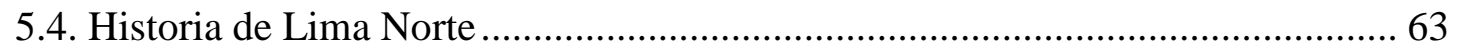

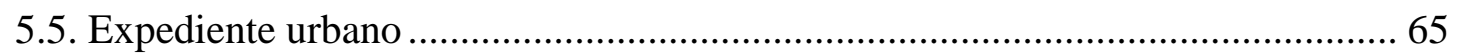

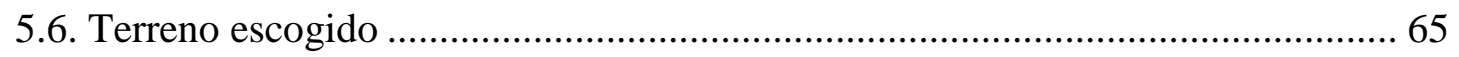

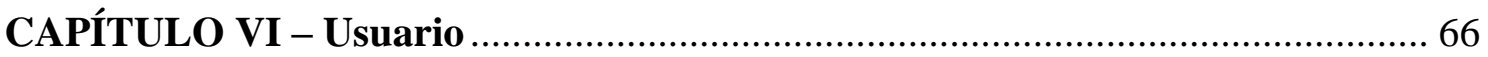

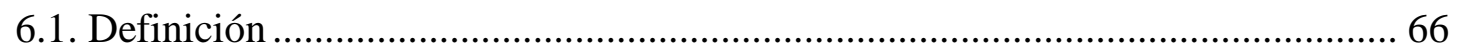

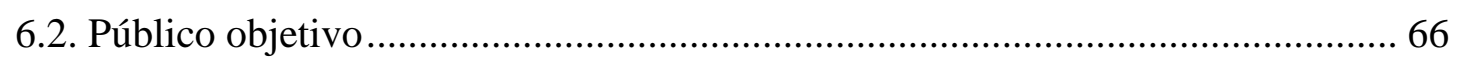

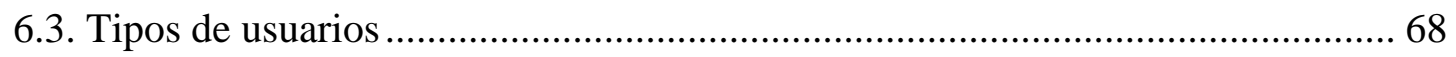

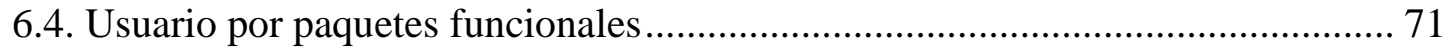

6.5. Usuario del área de formación y difusión cultural .............................................. 72

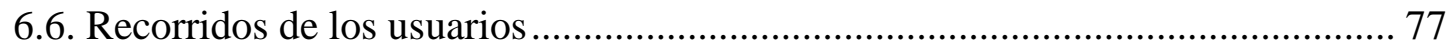

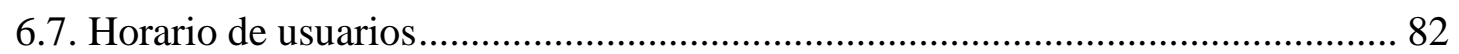

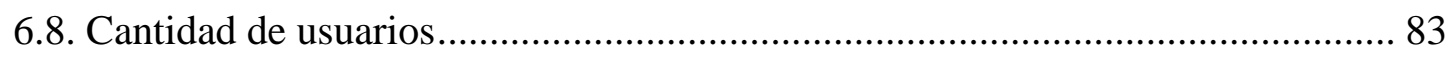

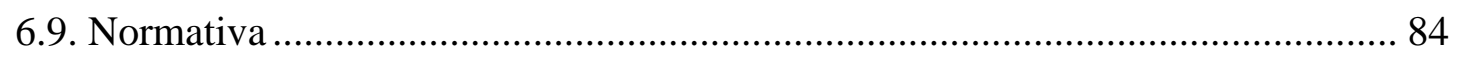

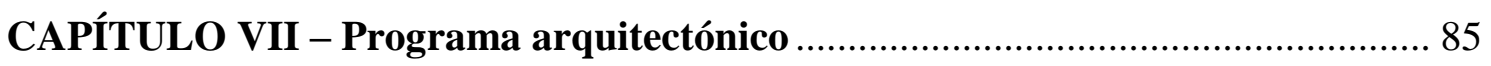

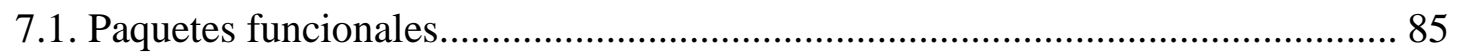

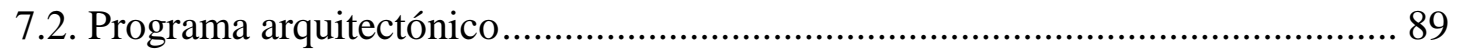

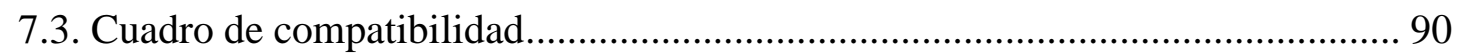

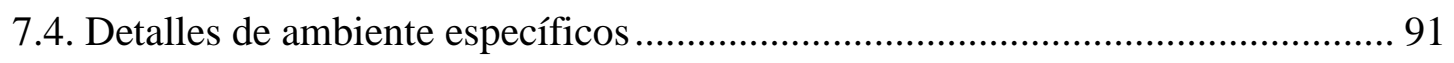

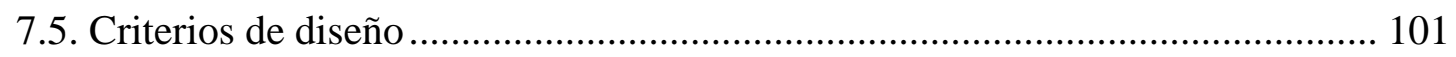

CAPÍTULO VIII - Referencias .................................................................... 102 


\section{INDICE DE TABLAS}

Tabla 1: Cuadro de escuela de artes más conocidas en el Perú ....................................... 43

Tabla 2: Tabla de usuario por paquete funcional ......................................................... 71

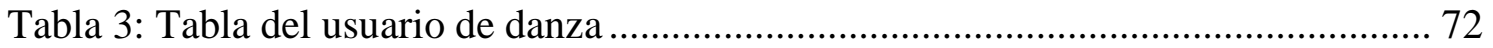

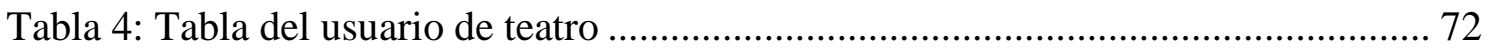

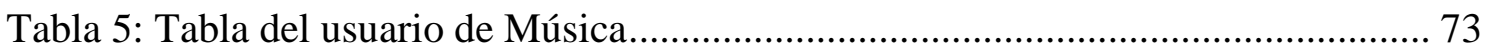

Tabla 6: Tabla del usuario de TAE (Terapia de artes expresivas)............................... 73

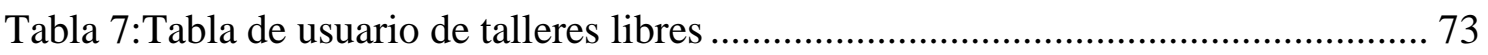

Tabla 8: Tabla de usuario invitado o eventual............................................................. 74

Tabla 9: Tabla de usuario de la zona administrativa ................................................... 74

Tabla 10: Tabla de usuario de la dirección académica................................................... 74

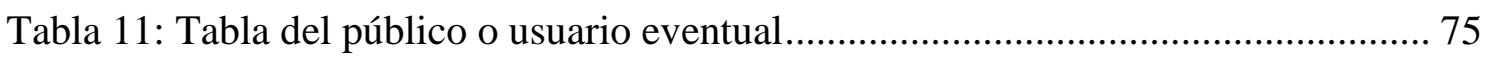

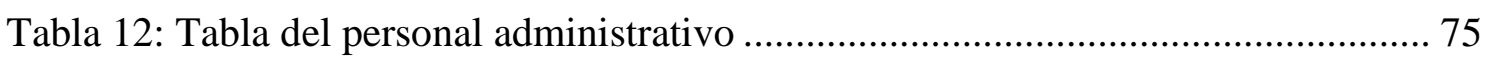

Tabla 13: Tabla del área de dirección y producción..................................................... 75

Tabla 14: Tabla del área de marketing y publicidad …................................................. 75

Tabla 15: Tabla del personal de soporte técnico ......................................................... 76

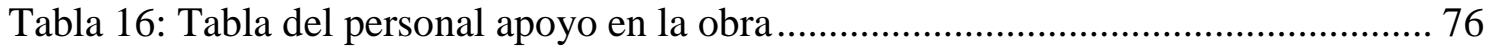

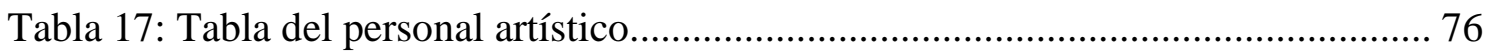

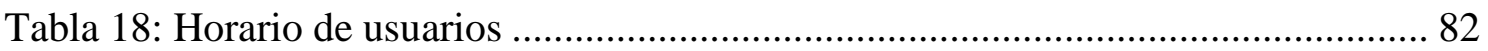

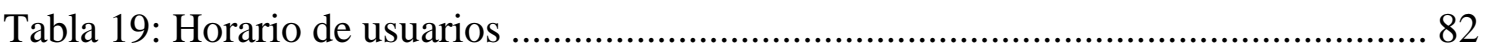

Tabla 20: Tabla de crecimiento poblacional en SMP (2010-2015)/Elaboración propia 83

Tabla 21: Tabla de paquete funcional, zona administrativa / Elaboración propia ......... 85

Tabla 22: Tabla de paquete funcional, zona de servicio / Elaboración propia................ 85

Tabla 23: Tabla de paquete funcional, zona de dirección y docencia / Elaboración propia

Tabla 24: Tabla de paquete funcional, zona de servicios complementarios / Elaboración

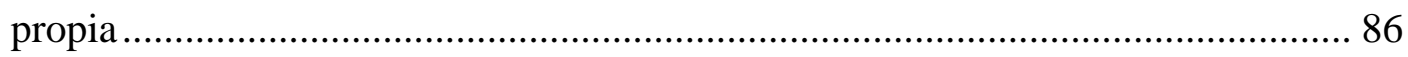

Tabla 25: Tabla de paquete funcional, zona académica / Elaboración propia ................ 86

Tabla 26: Tabla de paquete funcional, zona de difusión / Elaboración propia ............... 87

Tabla 27: Tabla de paquete funciona, Zonas públicas / Elaboración propia ................... 88 


\section{INDICE DE FIGURAS}

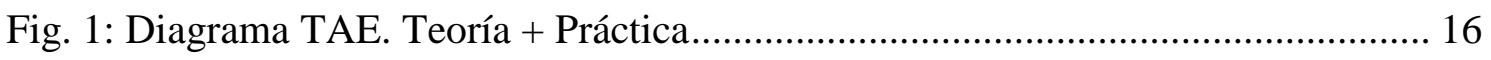

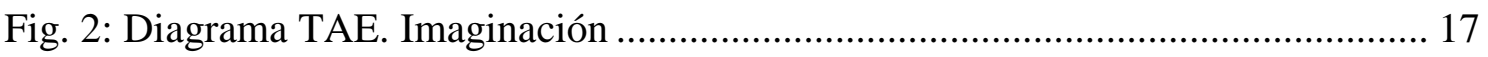

Fig. 3: Sección del Teatro griego de Epidauro; Grecia, 300 a. C................................. 27

Fig 4: Sección del Teatro romano de Aspendos; Turquía, 155 d. C............................... 28

Fig. 5: Teatro all' Antica de Sabbioneta, V. Scamozzi, 1590 ..................................... 29

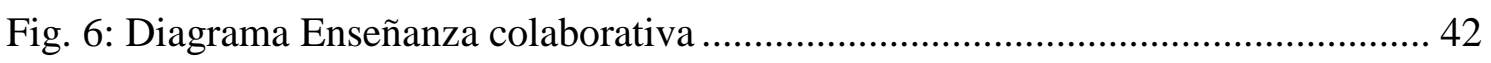

Fig. 7: Diagrama. Elaboración propia …............................................................... 52

Fig. 8: Diagrama de espacios. Elaboración propia ..................................................... 52

Fig. 9: Relación espacial /Elaboración propia ….............................................................. 53

Fig. 10: Organización espacial/Elaboración propia...................................................... 53

Fig. 11: Mapa de concentración de equipamientos culturales en Lima.......................... 60

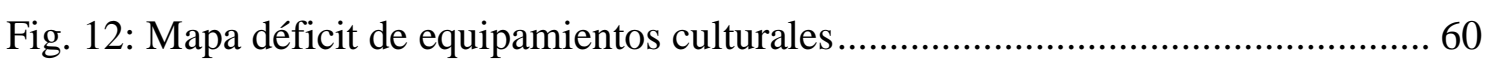

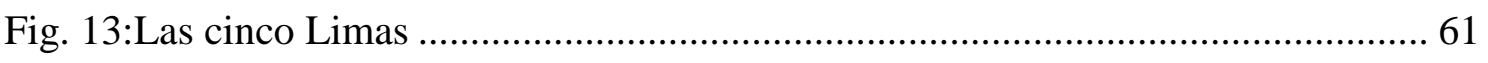

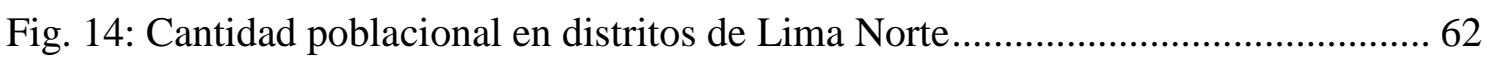

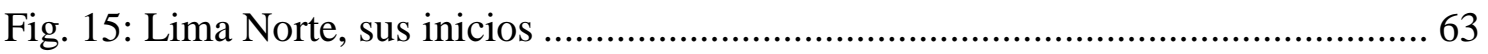

Fig. 16: Línea de tiempo Lima Norte/Elaboración propia................................................. 64

Fig. 17: Esquema del recorrido de alumno/Elaboración propia .................................. 77

Fig. 18: Esquema del recorrido del personal administrativo/Elaboración propia .......... 78

Fig. 19: Esquema del recorrido del usuario externo y padre de familia/Elaboración propia

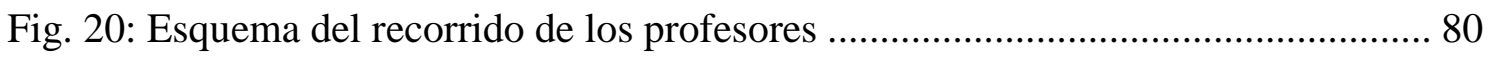

Fig. 21: Esquema del recorrido del personal de limpieza........................................... 81

Fig. 22: Cuadro de compatibilidad por paquetes funcionales / Elaboración propia....... 90

Fig. 23: Cuadro de compatibilidad por ambientes / Elaboración propia ........................ 90

Fig.24: Planta Estudio de enseñanza personalizada .................................................. 91

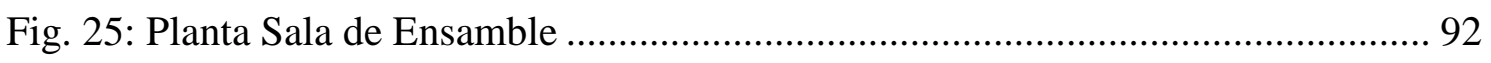

Fig. 26: Planta de Sala de Práctica Coral...................................................................... 93

Fig. 27: Sala de Práctica de Orquestas y/o Bandas ...................................................... 94

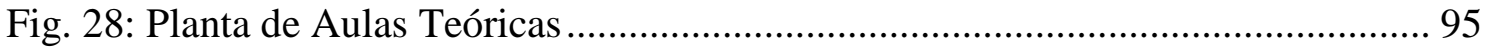

Fig. 29: Planta de Estudio de Danza Grande ................................................................... 96

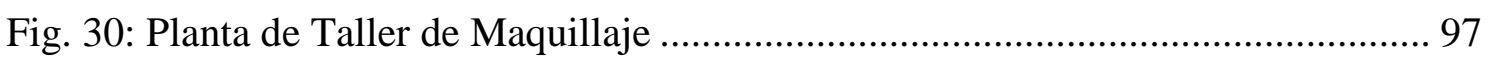




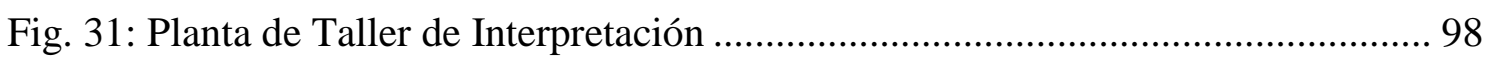

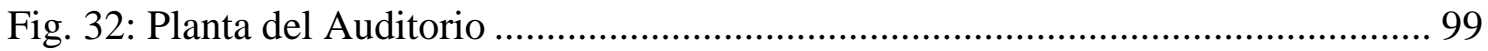

Fig. 33: Análisis antropométrico del auditorio.......................................................... 100 


\section{CAPÍTULO I}

\subsection{Introducción}

La zona norte de la ciudad de Lima comprendida por los distritos de Carabayllo, Ancón, Puente Piedra, San Martín de Porres, Santa Rosa, Comas, Independencia y Los Olivos, se consolidó, morfológicamente, gracias a los ejes que unen el centro de la ciudad con la zona norte de Lima. Estos ejes son las avenidas Túpac Amaru, la Panamericana Norte y la avenida Universitaria que han permitido que en este sector se asienten migrantes provenientes, en su mayoría, del norte del país. Actualmente, esta migración engloba más grupos étnicos del Perú, quienes han logrado durante décadas desarrollarse y consolidarse económica y urbanísticamente.

"Lima Norte ha adquirido mayor notoriedad, dado su incremento económico a partir del año 2001. Prueba de ello es que los distritos, Los Olivos y San Martin de Porres, han elevado sus categorías de sectores socioeconómicos C y D hacia B y C, respectivamente. Este crecimiento se refleja en la gran cantidad de negocios que se han desarrollado en los alrededores del centro comercial Mega Plaza y Plaza Norte”. (El Comercio, 2011)

"Sin embargo, para poder seguir creciendo, se tiene que resolver una serie de problemas como la pobreza, el desorden y el analfabetismo. Al igual que el resto del país, la calidad educativa es muy baja y mejora lentamente". (Yzusqui, 2010)

Para poder seguir creciendo como país, hay que combinar este desarrollo económico con un desarrollo cultural; no obstante, este desarrollo se quebrará. En tal sentido, la educación de calidad debería darse por igual en todo el país; debería descentralizarse. "Hay que llevar a cabo una reforma en la educación y llevarla ya, pues es la que más demora en dar resultados". (Olivares, 2010) 
"Hoy el arte da a conocer a través de sus múltiples expresiones, las formas más características de una cultura. El arte, al manifestarse creativamente con la cultura misma como material, es capaz de provocar cambios, ayudar al cambio, modificar, o hacer aceptables sentidos culturales no existentes anteriormente”. (Umberto Eco, 1970) Por lo tanto, es posible que el arte se convierta en agente de cambio.

El apoyo hacia las artes ha venido incrementándose desde varios años atrás, a paso lento, ya que no cuenta con el apoyo económico de entidades gubernamentales, debido a que estas se han enfocado en solucionar otros problemas de la población limeña. El deterioro que presentan los centros destinados a la enseñanza de artes, la falta de espacio y sus malas adaptaciones de equipo e infraestructura en Lima Norte son una problemática para el desarrollo cultural como también lo es para el propio desarrollo del artista. La existencia de festivales al aire libre, como FITECA (Fiesta Internacional de Teatro en Calles Abiertas) donde han pasado grupos peruanos como Yuyachkani, La Tarumba, Patacláun, entre otros invitados internacionales, demuestra la aceptación y difusión de las artes escénicas en el lugar, formando a jóvenes talentosos y alejándolos de las drogas y el mal vivir. (Ministerio de Cultura, 2015)

Queda claro que la arquitectura cumple un papel fundamental a la hora de crear espacios que motiven al usuario a desarrollar actividades artísticas. A través de ella, podemos desarrollar jóvenes más capacitados en el arte escénico y ayudar con el crecimiento social de la población, que cada día necesita expresar su arte.

De esta manera el proyecto de investigación ha sido desarrollado para llegar a una conclusión que satisfaga los objetivos principales: descentralizar los centros de formación y difusión de artes proponiendo un nuevo núcleo artístico en Lima Norte, promover terapias a través de actividades plásticas, corporales y musicales, dotar de una relación y organización espacial capaz de estimular nuevas situaciones y entornos para el aprendizaje de las artes. 


\subsection{Problemas}

\subsubsection{Problema principal}

"El encuentro entre actores y público puede ser un acto cuya complejidad trasciende el terreno de lo intelectual, llevándolo al campo de lo sensible y espiritual. Para esto, el actor necesita compartir con el otro su esencia a través del escenario. El cine o la televisión no pueden crear esos vínculos, uno no se puede relacionar con una pantalla, por más que le gritemos al televisor el actor nunca lo podrá escuchar, son sistemas cerrados, unilaterales, incapaces de permitir la transformación de la obra artística. De ahí la importancia de la interacción escénica: el teatro existe cuando actores y espectadores se integran en una pequeña sociedad efímera”. (Peter Brook, 1973)

La arquitectura juega un rol muy importante, ya que depende mucho del espacio para que esa relación entre el artista y el público se logre. El problema general se basa en cómo lograr una secuencia espacial donde el artista sienta fluidez y continuidad del espacio a lo largo de su recorrido, desde los espacios teóricos o de formación hasta los prácticos. La fluidez y continuidad no son solo términos influyentes en la arquitectura, sino también en las artes escénicas, y si se logra esa conexión en el espacio arquitectónico y el artista, se logrará lo mismo en la relación del artista y el público.

\subsubsection{Problema secundario}

- Espacios inadecuados para la enseñanza de Artes. Adaptación de Escuelas de Artes a infraestructuras antiguas en riesgo o edificaciones en deterioro por falta de apoyo económico de parte del gobierno y falta de oportunidades financieras para el desarrollo y la difusión de esta rama escénica.

- Falta de apoyo a la educación cultural. No existe una verdadera conciencia de lo que significa el arte en todas sus dimensiones.

- Centralización de centros culturales. La mayor parte de estos se encuentran localizados en el casco histórico de la ciudad, centralizando toda la riqueza cultural en un solo sector, dejando el resto de zonas sin ningún medio o centro que enriquezca la cultura y el arte de la población. 


\subsection{Objetivos}

\subsubsection{Objetivo principal}

Cuando vamos a una escuela de artes expresivas, buscamos aprendizaje, la distracción, recreación, etc. Por medio de un espacio abierto al público y de calidad arquitectónica, el proyecto plantea conectar al usuario con el arte y las distintas ramas de las artes escénicas. El objetivo principal del proyecto es dotar de una relación y organización espacial capaz de estimular nuevas situaciones y entornos para el aprendizaje de las artes escénicas. El proyecto ofrece un complemento a la educación básica, un lugar distinto, que se distinga por su relación con la ciudad, la arborización y la combinación de las diversas actividades planteadas.

En conclusión, la integración, conexión y relación de espacios son los objetivos del presente tema de investigación. Asimismo, el proyecto pretende apoyar el proceso de modernización que vive el país, acercando al público en general a enfoques interactivos, críticos e integrales sobre el desarrollo cultural a través de las corrientes de vanguardia.

\subsubsection{Objetivo secundario}

- Determinar cómo se puede despertar mayor interés hacia las artes escénicas y lograr que la misma infraestructura sea un medio de difusión de arte estimulando la formación de nuevo público y ampliando el mercado de trabajo de nuestros artistas.

- Descentralizar los centros de formación y difusión de artes proponiendo un nuevo núcleo artístico en Lima Norte, debido a los festivales de arte callejero (danza, música, teatro) que se desarrollan en la zona, el cual no cuenta con espacios específicos para su desarrollo. 


\section{CAPÍTULO II - Marco teórico / referencial}

\subsection{Definición de artes expresivas}

Las artes expresivas son la combinación de las artes visuales, movimiento (danza), música, escritura (poesía) y otros procesos creativos para fomentar el crecimiento personal y social. A través de estos procesos, la creatividad puede expresar el mundo interno de la persona: tanto las cosas positivas como las negativas, las fortalezas como las debilidades, las alegrías, los miedos y las tristezas. Si me preguntan a mí qué son las artes expresivas, podría definirlas simplemente como la expresión espontánea del mundo interior.

\subsection{Ramas que lo conforman}

\subsubsection{Terapia de Artes Expresivas (TAE)}

La TAE es una terapia cuyo desarrollo en el mundo se da desde los años 60's. Época en la que los científicos y estudiosos, reconocen que el ser humano es mucho más que su psique: una unidad cuya conciencia es corporal, mental y espiritual. De allí que este tipo de terapia trabaja con el cuerpo, la mente y el espíritu del paciente, despertando y desarrollando su conciencia en estos tres niveles, a través del arte como medio de expresión de su belleza y de su dolor. (Alalú, 2017)

La capacidad humana de crear e imaginar es diversa. Transita entre sonidos, movimientos, lo visual, lo plástico, etc. Por eso, este tipo de terapia usa las diferentes modalidades de la imaginación humana para que cada persona pueda dar forma a su vida, utilizando distintos medios artísticos, trascendiendo con ingenio y creatividad las dificultades y los retos que estemos enfrentando en nuestra vida. Ya sean pasados o del momento presente.

La terapia de artes expresivas (TAE) es un modelo terapéutico de desarrollo humano, grupal o individual, que se basa en el uso de las artes para el descubrimiento, uso y manejo de los recursos que cada persona tiene para trascender sus dificultades. En la TAE se busca explorar el alma de las personas a través de las artes. 
En este enfoque terapéutico tanto la terapeuta como el paciente, se encuentran en la creación de un trabajo artístico. Y esto le permite a la terapeuta acompañar y atestiguar los recursos que esta persona tiene para enfrentar sus retos y así atender sus limitaciones.

Esta terapia es para todos. No solo para quienes se consideran artistas. Y es que se basa en el supuesto de que todos tenemos la capacidad de ser creadores de nuestra vida y de dar forma a nuestra experiencia, a través de nuestros propios gustos, en eso que nos hace únicos y especiales. (Alalú, 2017)

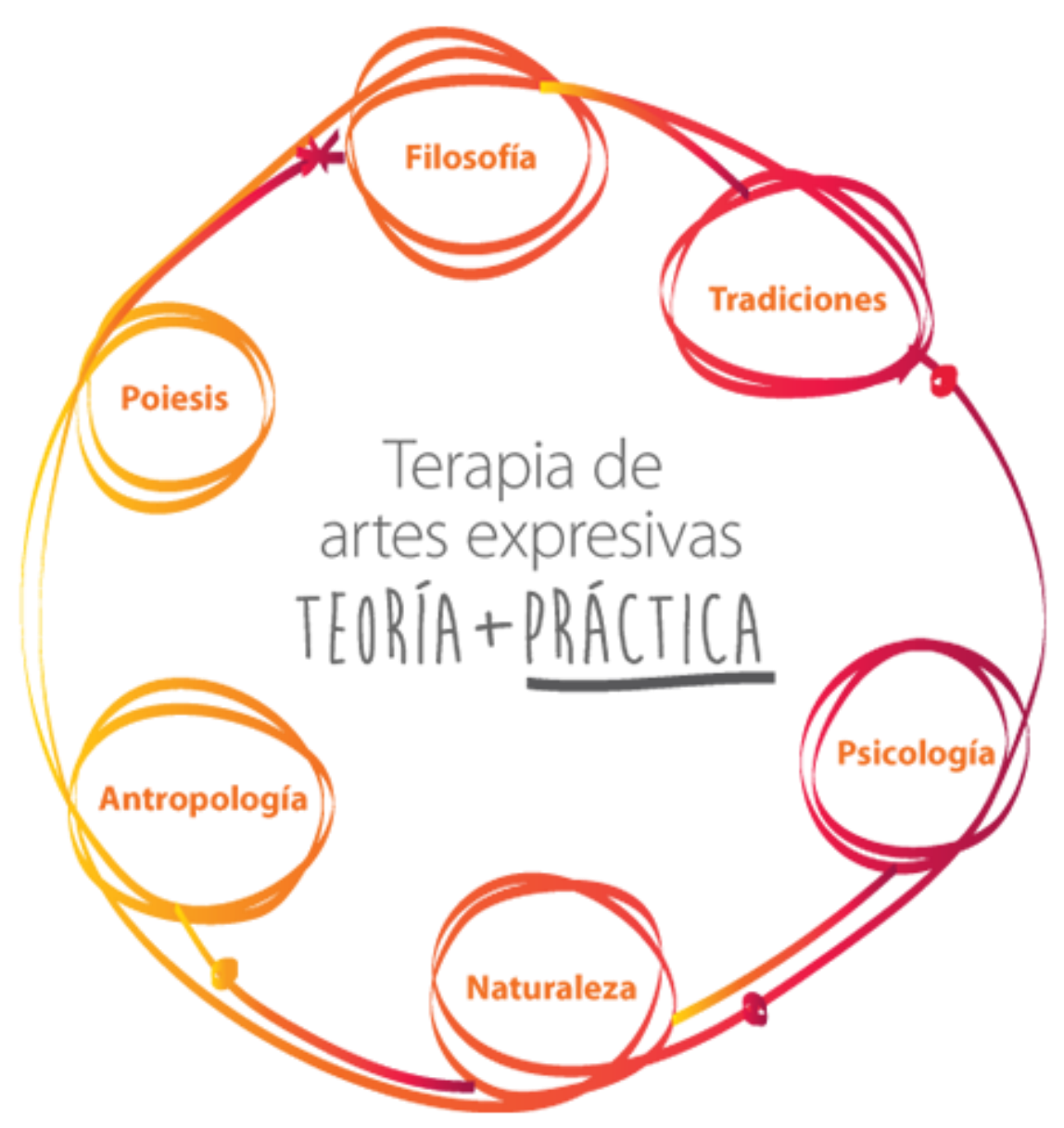

Fig. 1: Diagrama TAE. Teoría + Práctica 


\section{¿Quiénes pueden hacer Terapia de Artes Expresivas?}

Personas que están experimentando:

- Dolor físico o emocional, Y/o Trauma

- Adicciones o hábitos dañinos

- Transiciones, decisiones importantes y necesidad de cambio

- Acompañamiento durante el embarazo o depresión post parto

- Duelo o pérdida de seres queridos, relaciones, trabajo, etc.

\section{El acompañamiento que brinda la TAE es excelente para quienes buscan:}

- Crecimiento y cambio personal

- Incrementar su bienestar y balance físico, emocional y espiritual

- Prepararse para el parto o la maternidad/paternidad

- Acompañar procesos de duelo, o transición de seres queridos

- Crecimiento espiritual y enriquecimiento de su práctica

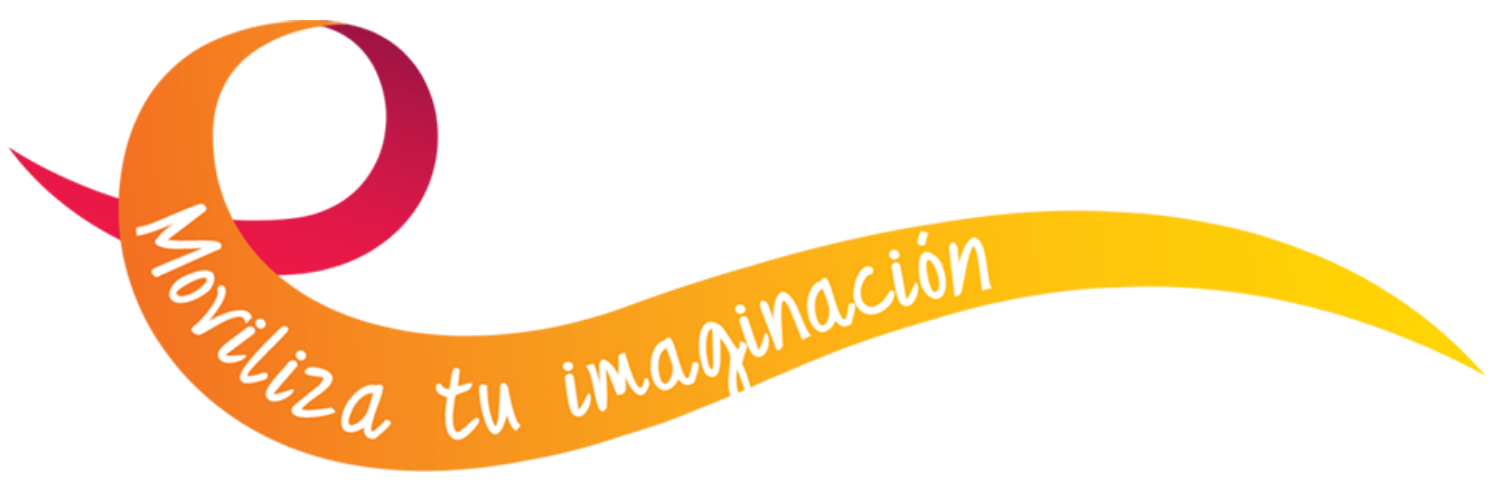

Fig. 2: Diagrama TAE. Imaginación 


\subsubsection{Artes Escénicas}

"Las artes como el teatro, el circo, la danza, la ópera y otras de creación más reciente, como la performance, constituyen manifestaciones socioculturales y artísticas que se caracterizan tanto por los procesos comunicativos singulares que le son propios, como por el hecho de que se materializan en la escena a través de la síntesis e integración de otras expresiones artísticas, desde las literarias hasta las plásticas.

La materia denominada Artes escénicas se concibe como un instrumento fundamental en una formación integral, ya que no sólo se ocupa del estudio de las diferentes manifestaciones de la teatralidad, sino que, además, permite que el alumno desarrolle competencias comunicativas, sociales, expresivas, creativas o las relacionadas con la resolución de problemas y la autonomía personal, estimulando su interacción con el medio y garantizando, por tanto, el logro de fines formativos y propedéuticos asignados a esta etapa”. (Departamento de Educación y Cultura ,Gobierno de Navarra)

"La materia de Artes Escénicas y Danza permite ir descubriendo con los alumnos y las alumnas, a través de su propia experiencia, el desarrollo de sus propias capacidades artísticas creativas e interpretativas y comprendiendo así la necesaria relación entre los aspectos teóricos y prácticos de la materia.

Por último, la materia de Artes Escénicas y Danza trata, en esencia, de contribuir al enriquecimiento del acervo cultural del alumnado y de sus posibilidades de expresión, enseñándole a apreciar tanto la belleza de las obras, espectáculos y montajes que ilustraron culturas pasadas como las que sustentan nuestro presente". (Estudio del Sector de las Artes Escénicas en Aragón, 2007)

A partir de estas definiciones se puede entender como arte escénico: el conjunto de disciplinas artísticas que tienen como principal característica el manejo de la actividad corporal y el uso de los sentidos; y además éste se desarrolla siempre en un escenario. 


\section{Ramas que lo conforman}

Entre las principales ramas del arte escénico, encontramos tres: el teatro, la danza y la música; cada una de ellas con estilos y géneros diferentes que se han ido desarrollando a lo largo de la historia. Además de estas tres ramas principales, el arte escénico también abarca los espectáculos como el circo, el cabaret, los monólogos, entre otros, que son derivados de las tres principales ramas, dado que en la antigüedad las culturas personalizaban su propia manera de representación escénica.

\section{- TEATRO}

El término teatro procede del griego "theatron", que puede traducirse como el espacio o el sitio para la contemplación. (Diccionario de la Real Academia de La Lengua Española, s.f.) $\mathrm{Su}$ desarrollo está vinculado con actores que representan una historia ante una audiencia. Este arte, por lo tanto, combina diversos elementos, como la gestualidad, el discurso, la música, los sonidos y la escenografía.

"Por otra parte, el concepto de teatro se utiliza para nombrar al género de la literatura, que abarca aquellos textos pensados para su representación en escena, y también al edificio donde se representan las piezas teatrales”. (Avitia Hernández, 2011)

\section{- DANZA}

"La danza o el baile es un arte donde se utiliza el movimiento del cuerpo usualmente con música, como una forma de expresión, de interacción social, con fines de entretenimiento, artístico o religioso. Es el movimiento en el espacio que se realiza con una parte o todo el cuerpo del ejecutante, con cierto compás o ritmo como expresión de sentimientos individuales, o de símbolos de la cultura y la sociedad”. (Marcelle Michel, 1995)

\section{- MÚSICA}

"El término como tal de música viene de la antigua Grecia, y significa el arte de las musas. La música es el arte de organizar sensible y lógicamente una combinación coherente de sonidos y silencios utilizando los principios fundamentales de la melodía, la armonía y el ritmo, mediante la intervención de complejos procesos psico-anímicos.” (Michels, 1985) "La finalidad de la música es proporcionar una experiencia sensorial en el oyente, aunque va mucho más allá. La música proporciona emociones, y las evoca; por lo que es un fenómeno muy, pero que muy popular en nuestros días”. (Michels, 1985) 


\section{$\underline{\text { TEATRO }}$}

\section{A. HISTORIA Y ANTECEDENTES}

"El teatro nació en el momento en que el hombre, por la creación de mitos, dioses y seres superiores, tenía que rendirles algunas ofrendas para obtener beneficios y parabienes. En Grecia surgió con el Ditirambo, que consistía en bailar y cantar en torno a Dionisio, el Dios del vino y la fertilidad. Las representaciones teatrales se iniciaron en festividades dedicados a danza y representaciones mímicas. Pero estas escenas tienen su origen en el hombre primitivo, que al realizar danzas y ciertos movimientos rítmicos en honor al fuego, al sol, a la lluvia el agua y otros fenómenos naturales, inicia los ritos religiosos y las representaciones aunque muy rudimentarios, son el origen del teatro.” (Ulrich, 2004)

\section{B. EVOLUCIÓN DEL TEATRO}

"El teatro es un género literario que se creó con el fin de representar obras literarias de carácter dramático. Como se sabe, las artes escénicas tratan todo lo relativo a la escritura, la interpretación y la producción. A lo largo del tiempo se ha utilizado desde las celebraciones religiosas, hasta un medio de promover ideas políticas, difusión de propagandas, entretenimiento y como arte cultural". (Infoartes, 2015) El teatro, además de lo ya mencionado, también se puede entender como el espacio arquitectónico designado para la representación de las obras teatrales. Siendo esta una investigación de la rama de arquitectura, se hará un estudio de la evolución del teatro como espacio arquitectónico, desde sus orígenes hasta la actualidad.

\section{METODOLOGÍA DE ENSEÑANZA}

“Actuación es la acción y efecto de actuar (poner en acción, asimilar, ejercer funciones, obrar o producir un efecto). El término suele utilizarse para nombrar a la puesta en escena que realiza un actor (una persona que interpreta un papel ya sea en el teatro, el cine, la televisión u otro medio).

Las técnicas de actuación modernas surgen de las prácticas de grandes directores de teatro como Konstantin Stanislavski, Jerzy Grotowski, Antonin Artaud, entre otros; a partir de la búsqueda de nuevas formas de representación actoral. Muchas de estas técnicas nacen a partir de teorías psicoanalíticas”. (Infoartes, 2015) 
A continuación, se analizarán las metodologías más conocidas para una comprensión del aprendizaje de la actuación.

\section{- Método Stanislavski}

"Konstantin Stanislavski es el creador del que se considera el más influyente de los métodos de interpretación. Su método consiste en llevar a los actores a experimentar sentimientos similares a los del personaje que interpretan por medio de acciones y con ayuda de la "Memoria Emocional". Es decir, que si por ejemplo el personaje tiene que llorar, el actor trata de sentirse triste rememorando alguna escena de su pasado, se lleva las manos a los ojos y suspira para, tras todo esto, poder desencadenar el llanto". (Stanislavski, 1980)

\section{- Método Michael Chekhov}

"Su técnica difiere de la de Stanislavski en que Chekhov desarrolló lo que denominó Gesto Psicológico que consiste en realizar un movimiento físico que exprese la psicología (pensamientos, sentimientos y voluntad) del personaje a interpretar". (National Michael Chekhov Association, s.f.)

\section{- Método Lee Strasberg}

"El Método es una versión de la técnica de Stanislavski popularizada en Nueva York por el Group Theatre, un colectivo de teatro formado en 1931. Constituye una exacerbación de las ideas del primer Stanislavski, ahondando en su línea psicologista ingenua. Strasberg estimaba que muchos problemas de la actuación, especialmente los vinculados con la expresividad, que no habían sido desentrañados por el Sistema, habían hallado resolución en su Método. Las premisas fundamentales del mismo son la relajación y la concentración, dado que él creía que la clave del proceso creativo estaba en la memoria". (Osvaldo Pellettieri, 2003)

\section{- Método Meisner}

El actor Sanford Meisner se convirtió en un teórico de la interpretación, y su influencia ha sido decisiva en el mundo de la actuación actual. No son pocos los actores y actrices que siguen su metodología. 
"Uno de los ejercicios más importantes de la Técnica Meisner es la Repetición, en la cual una persona empieza a hacer un comentario basado en otra persona que tiene enfrente. El comentario se repite una y otra vez hasta que la reacción cambia de manera natural en lugar de hacerlo mediante la manipulación”. (Cava, s.f.)

\section{- Método Stella Adler}

"Su metodología se basa en crear personajes a través de la imaginación, en contraste con la de Strasberg y el Método que enseñan a usar la memoria para definir al personaje". (Adler, s.f.)

\section{- Método Meyerhold}

Su metodología consiste en un conjunto de expresiones corporales que él creó y que los actores usarían para expresar ciertas emociones. "Esta técnica es opuesta al Método de Konstantin Stanislavski. El método de Meyerhold utiliza procesos tanto sicológicos como físicos junto con gestos y movimientos para expresar emociones”. (Artes Escénicas, s.f.) 


\section{GÉNEROS, ESTILOS Y TENDENCIAS}

\section{Géneros}

Géneros dramáticos mayores:

- Tragedia: Es una obra de asunto terrible y desenlace funesto, en la que intervienen personajes ilustres o heroicos.

- Comedia: Género dramático tradicional, contrapuesto a la tragedia.

- Drama: La pretensión del drama es ser un reflejo de la vida, de personajes, situaciones y conflictos cercanos a los vividos por los espectadores. A veces, tiende a la gravedad y pesimismo de la tragedia, y otras, al tono más amable de la comedia. (Escola Sant Gervasi, Cooperativa., s.f.)

\section{Géneros dramáticos menores:}

- Auto Sacramental: Texto teatral de tema religioso y personajes alegóricos de tema eucarístico.

- Entremés: Pieza teatral cómica, en un solo acto y de trama jocosa; surgido en España, en el siglo XVI; los entremeses eran representados en los intermedios de las jornadas de una obra.

- Sainete: Pieza jocosa de corta duración -inferior a un acto- de carácter y argumento popular, en la que se ridiculizan los vicios y convenciones sociales; derivado del entremés y con o sin canciones.

- Farsa: Pieza cómica destinada a hacer reír. La diferencia entre la farsa y la comedia reside en el asunto; que en la primera al contrario que en la segunda, no necesariamente tiene que ser convincente o cercano a la realidad.

- Monólogo: Pieza dramática interpretada por un solo actor, aun cuando en ella intervengan varios personajes; es un parlamento de extensión superior a lo habitual en los diálogos, pronunciado en solitario o en presencia de otros personajes.

- Vodevil: Comedia aligerada con canciones y bailes, de carácter marcadamente frívolo, alegre y de asunto amoroso, con marcada intriga y enredo; muy popular en Francia en los siglos XVIII y XIX. (Escola Sant Gervasi, Cooperativa., s.f.). 
Géneros dramáticos musicales:

- Ópera: Obra teatral compuesta para el canto. En ella confluyen literatura, música, danza, escenografía y artes plásticas.

- Zarzuela: Obra dramática y musical, en la que alternativamente se declama y se canta. Como género específicamente español, tiene sus orígenes remotos en la musicalización de distintos misterios y dramas.

- Opereta: Especie de ópera, de asunto frívolo y carácter alegre, en el que predomina la sátira.

- Revista o musical: Espectáculo teatral de carácter frívolo en el que alternan elementos dialogados y números musicales. (Escola Sant Gervasi, Cooperativa., s.f.)

\section{$\underline{\text { Estilos }}$}

- Comedia del arte: es un tipo de teatro popular nacido a mediados del siglo XVI en Italia y conservado hasta comienzos del siglo XIX. Como género, mezcla elementos del teatro literario del Renacimiento italiano con tradiciones carnavalescas (máscaras y vestuario), recursos mímicos y pequeñas habilidades acrobáticas.

- Expresionismo: estilo propio con aspectos comunes respetados por todos sus adeptos. El expresionismo fue un movimiento eminente mente heterogénea que convocó a diversos artistas con las más diferentes tendencias y niveles intelectuales, pero con una coincidencia: la reacción en común contra los postulados del simbolismo; es decir, básicamente surgió como un opuesto a este.

- Teatro musical: es una forma de teatro que combina música, canción, diálogo y baile, y que se representa en grandes escenarios.

- Pantomima: es un subgénero dramático del mimo y la mimodrama que consiste en representar una historia mediante la mímica, sin diálogos ni palabras; es decir, apoyando la narración con expresiones, gestos o movimientos corporales.

- Performance: es una muestra escénica, muchas veces con un importante factor de improvisación, en la que la provocación o el asombro, así como el sentido de la estética, juegan un papel principal. (Biblioteca Digital Universidad de Alcalá) 


\section{Tendencias}

- Teatro de Guerrilla: actuaciones sorpresa espontáneas en espacios públicos poco probable que un público desprevenido. Típicamente estas actuaciones tienen la intención de llamar la atención sobre un tema sociopolítico a través de las sátiras, protesta, y las técnicas carnavalescas. (Durland, Steven, 1998)

- Teatro documento: es una variante de la dramaturgia, una mezcla de propuestas teatrales con el periodismo, los testimonios y otros recursos que se basan en hechos verdaderos. (Favorini, 2012)

- Teatro Campesino o Chicano: se llama tanto al modelo teatral como al grupo de teatro callejero que, nacido en 1965 como guerrilla pacífica en la huelga de agricultores mexicanos en California, evolucionó a partir de 1970 hacia planteamientos profesionales y contenidos religiosos, nacionalistas y políticohumanitarios. (Broyles-González, 1994)

- Teatro del Pánico: es una expresión artística que pretende anunciar la locura controlada como supervivencia ante una sociedad en crisis de valores (la sociedad posmoderna). Sus autores sugieren un universo barroco, preciso, de un mundo delirante y matemático; una mezcla de contrarios: de amor y odio, tragedia y comedia, mal gusto y refinamiento estético, el sacrilegio y lo sagrado, lo individual y lo colectivo; el ritual ceremonial: en actos trascendentales de la vida; la visión onírica, y a veces cruel y satírica de la vida, la sinrazón del mundo; la repetición de las cosas, a veces se concibe el tiempo de manera circular. (Cuore Panic, s.f.)

- Teatro Pobre: se centra, sobre todo, en el trabajo del actor antes, durante y después de la puesta en escena. Grotowski define el teatro pobre como aquel que adolece de elementos considerados innecesarios para el desarrollo de una puesta en escena. Por ello, a diferencia de lo que él llama teatro rico, en el teatro pobre no es necesario el uso de elementos decorativos exagerados como fastuosas escenografías, maquillaje y vestuarios saturados, iluminación excesiva e incluso considera que puede carecer de efectos de sonido. (Grotowski, 1970) 


\section{E. ESPACIO ARQUITECTÓNICO EN LOS TEATROS}

\section{Tipología Arquitectónica}

Se entiende por tipología, el conjunto de características formales que comparten las edificaciones nacidas para dar una respuesta común a las necesidades que una actividad determinada plantea. Por tanto, es lógico afirmar que existe una tipología edilicia porque en un momento dado los usos que alberga hicieron necesaria su invención. Este sencillo pensamiento se halla en el trasfondo de la famosa frase del arquitecto americano Louis Sullivan "forms follows function". (Sullivan, 1896)

Pensemos ahora en los edificios escénicos y preguntémonos: ¿A qué necesidades tratan de dar respuesta hoy en día? ¿Y hace dos mil años? ¿A qué usos estaban destinados? Al analizar su evolución histórica, rápidamente nos damos cuenta de la existencia de una serie de rasgos formales que invariablemente se han dado en todas las tipologías teatrales, lo cual es completamente lógico, ya que hay unas necesidades básicas inherentes a las actividades escénico musicales que requieren una respuesta formal concreta.

\section{Los Teatros de la Antigüedad Clásica}

\section{Características Formales}

Las características formales comunes que encontramos, tanto en el modelo griego como en el romano son:

- “Eje de simetría longitudinal

- Cávea curva en pendiente. La zona destinada al público en los teatros clásicos adopta forma semicircular por ser ésta la geometría que minimiza las pérdidas acústicas de sonido directo que el actor proyecta sobre la audiencia.

- Escena elevada sobre el plano inferior del público

- Edificaciones al aire libre. Las tipologías teatrales dan sus primeros pasos acondicionando espacios exteriores para usos escénicos, lo cual fue posible gracias a las bondades del clima mediterráneo predominante en el ámbito geográfico ocupado por las civilizaciones clásicas.

- Piedra como material constructivo principal”. (Sevillano, 2013) 
Teatro Griego (Ilustración 3)

- “Cávea dispuesta sobre las pendientes naturales de las colinas (la arquitectura griega es arquitrabada. No emplea todavía arcos ni bóvedas).

- Edificación tras el escenario de dimensiones reducidas.

- Recintos “abiertos", es decir, el conjunto de la edificación no se cierra al exterior.

- Gran capacidad de aforo, mayor a la de los recintos romanos.

- Altura media de escenario de 3 metros.

- Gradas con inclinaciones moderadas: $26^{\circ}$ de pendiente (aprox.)." (Sevillano, 2013)

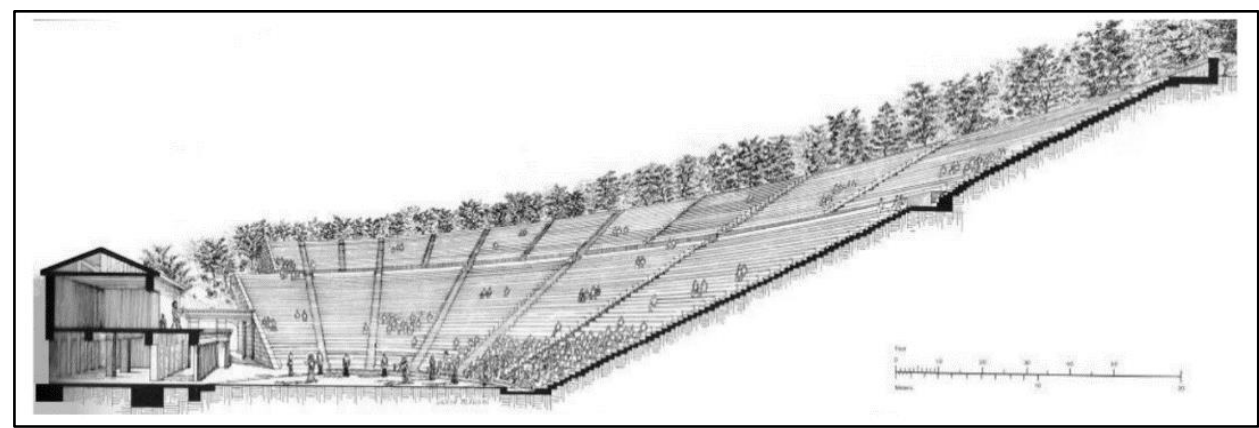

Fig. 3: Sección del Teatro griego de Epidauro; Grecia, 300 a. C.

(IZENOUR, G. C.: Theater Design, U.S.A., McGraw-Hill Book Company, 1977). 


\section{Teatro Romano (Ilustración 4)}

- “Cávea dispuesta sobre estructura de arcos o aprovechando las pendientes de las colinas (el empleo de arcos y bóvedas posibilita sistemas constructivos más complejos)

- Recintos “cerrados": la cávea estaba coronada por una logia posterior que quedaba enrasada con el scenae frons, formando un conjunto descubierto pero cerrado al exterior.

- Dimensión media, con capacidad más reducida que los teatros griegos.

- Altura del escenario reducida, en torno a 1,5 metros.

- Gradas con inclinación acusada: $32^{\circ}$ de pendiente (aproximadamente).

- Orchestra semicircular". (Sevillano, 2013)

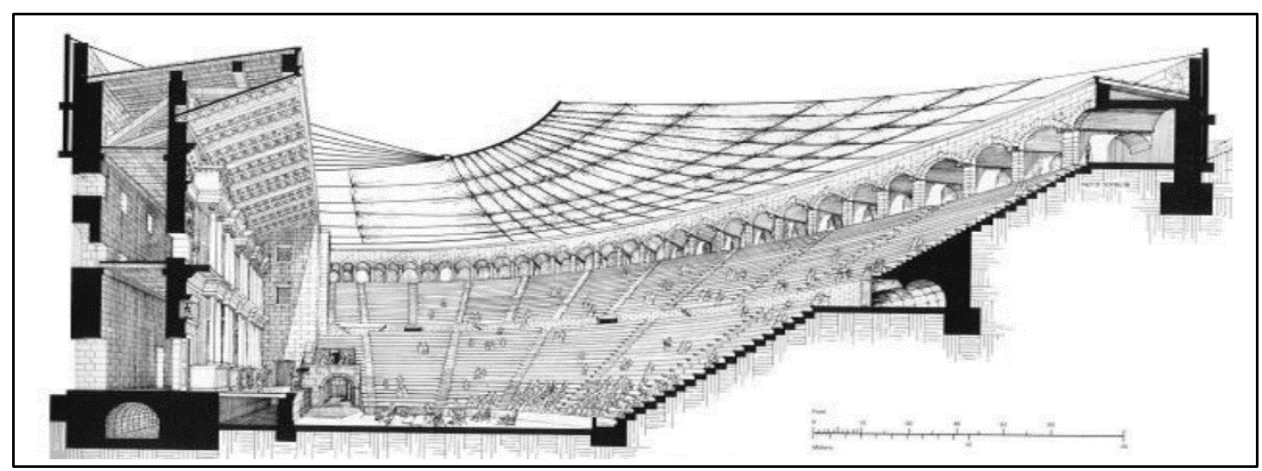

Fig 4: Sección del Teatro romano de Aspendos; Turquía, 155 d. C.

(IZENOUR, G. C.:op. cit.). 


\section{Edificios Teatrales del Renacimiento}

\section{Características Formales}

- "Dimensiones reducidas y aforo muy inferior al de los teatros de la antigüedad. semicircular, en los que se desarrollaban actividades musicales y de declamación.

- Cávea curva de herencia clásica que, desde este momento, será reinterpretada continuamente a lo largo de tres siglos dando lugar a la multitud de geometrías curvas que encontramos en los modelos teatrales posteriores.

- Frente escénico fijo al modo clásico, que poco a poco irá avanzando hacia los grandes escenarios vacíos del siglo XVIII en los que la ambientación teatral, los decorados y los efectos escénicos concentrarán el protagonismo visual del público.

- Materiales constructivos. Predominio de los acabados interiores en madera, lo cual afecta de forma directa a las condiciones acústicas de los recintos." (Sevillano, 2013)

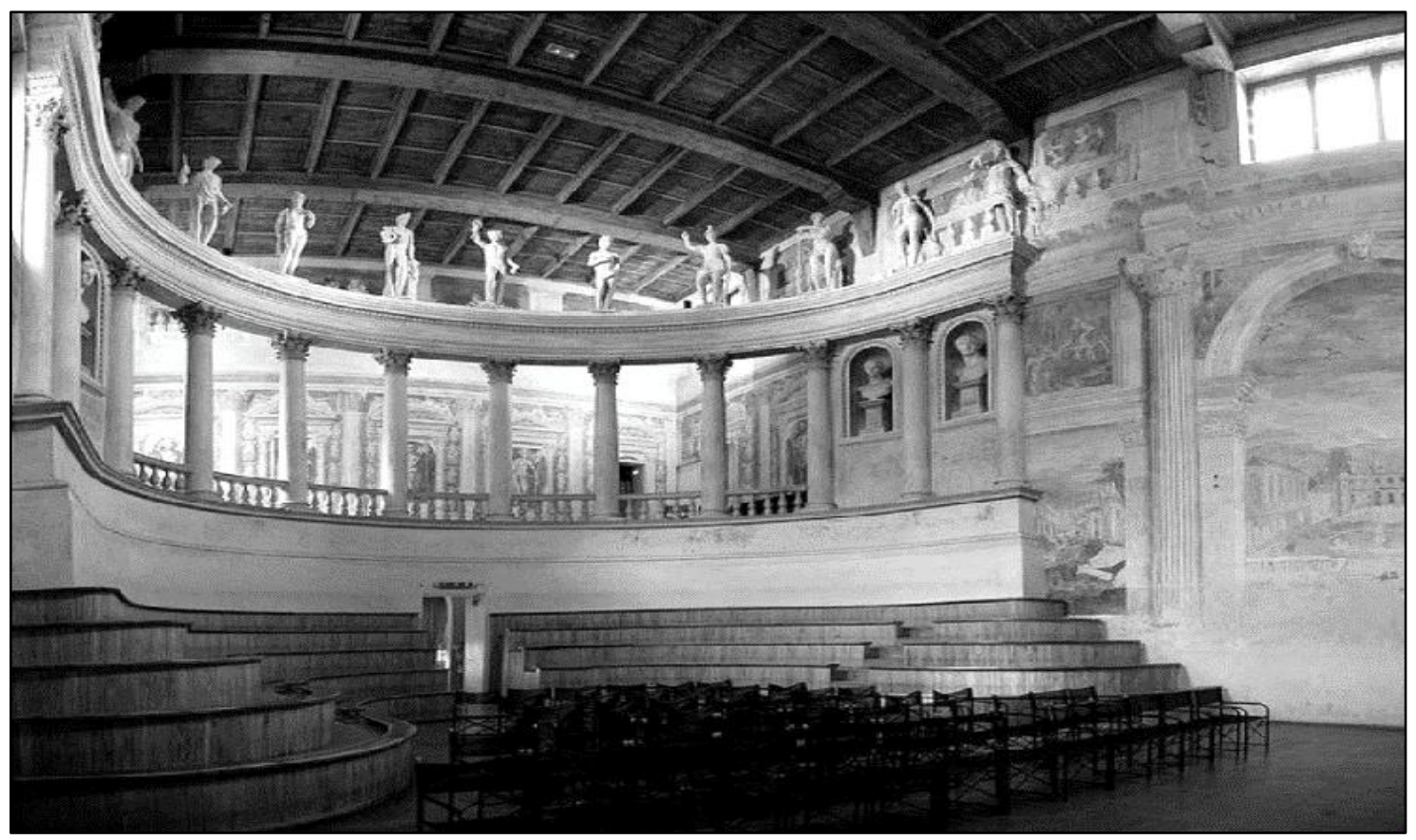

Fig. 5: Teatro all’ Antica de Sabbioneta, V. Scamozzi, 1590.

(IZENOUR, G. C.:op. cit.). 


\section{Espacios de formación}

Correspondiente a todos los espacios donde no existe relación con el público; sino más bien, son espacios de aprendizaje donde el artista es capacitado en su rama para perfeccionar su talento. Aquí se encuentran las aulas, los talleres, los laboratorios especializados y ambientes de formación teórica. Sin embargo, existen espacios como las salas de ensayo, que son espacios personalizados y acondicionados para el aprendizaje teórico-práctico, los cuales requieren dimensiones y características diferentes que las aulas tradicionales.

\section{Espacios de difusión}

Correspondiente a los espacios de representación; es decir los escenarios, los espacios de interacción con el público. En el caso de la actuación, el espacio correspondiente al teatro fundamentalmente.

\section{6. Áreas y proporciones}

Ambientes que se requieren y sus características:

- Aulas teóricas comunes para un máximo de 30 a 35 alumnos.

- Talleres prácticos grupales, para un máximo de 12 a 15 personas y las condiciones de estos espacios deben ser de preferencia de doble altura, piso hueco de madera, iluminación cenital y ventilación natural. Además, deben contar con depósitos para materiales, vestuario y utilería.

- Salas de ensayo, llamada comúnmente "Caja Negra" o "Black Box", que tiene similitud a un escenario. Sus condiciones y características son: espacio amplio y alto, de doble o triple altura, es fundamental que esté cerrado para el tema de la buena acústica, tiene un interior donde predomina el color negro, ya que así se puede adaptar a las diferentes escenografías, destinado también al ingreso del público con un aforo de 200 personas aproximadamente, y debe contar con depósitos para utilería y vestuario, cabinas para el control de sonido y luz. Flexibilidad de este espacio es acondicionado para poder usarse tanto en el teatro como en la danza y la música. 
- Sala de espectadores y escenario. La superficie se da por la cantidad de espectadores, y se determina aproximadamente $0.5 \mathrm{~m} 2$ por espectadores. Este resultado es la consecuencia del ancho del asiento y la separación entre filas.

- Isóptica. La proporción de una sala de teatro es fundamental para el ángulo visual del espectador y dependiendo de este ángulo, es que las medidas serán las adecuadas. La separación entre el borde del escenario y la última fila no debe exceder los 24 metros en los teatros y 32 metros en las óperas.

- Pendiente. Cada fila necesita una sobreelevación de 12cm. (Neufert, 2013)

Proporciones del escenario. Se distinguen 3 diferentes tipos de escenarios, donde se aplica a establecimientos con una capacidad mayor a 100 espectadores:

- Escenario Grande, superficie escénica con más de 100 m2, el techo del escenario debe estar mayor a $1 \mathrm{~m}$ por encima de la boca del escenario. Además, debe existir una amplia separación entre el escenario y las butacas.

- Escenario Pequeño, superficie escénica menor a $100 \mathrm{~m} 2$, no requiere posibilidades de ampliación, el techo del escenario puede estar a menos de $1 \mathrm{~m}$ por debajo de la boca del escenario y no requieren un telón de acero.

- Superficies destinadas a representaciones, tarimas elevadas en la sala, incluye una galería superior para decorados y los espacios experimentales como la "caja negra" se incluyen en este caso. El tamaño promedio de una caja negra es de $12 \mathrm{~m}$ x 16m (192 m2 aproximadamente). (Neufert, 2013)

\section{Iluminación escénica}

Cumple dos principales funciones: iluminar el escenario y a los actores y transformar el escenario en una atmósfera perfecta a la obra. (Vicente, 2016)

"Poca iluminación: el espectador se siente incómodo porque no ve.

Demasiada iluminación: se producen brillos, se pierden colores y volúmenes. 
Existen diferentes tipos de iluminación en los teatros:

- Luz de panorama: Para evitar que se dibujen sobre el fondo las líneas de luz, se utilizan filtros difusores.

- Luz cenital: Cae en vertical sobre el objeto.

- Luz frontal: Es la luz más usada para la iluminación general de una escena.

- La contra: Es la luz que incide sobre el objeto desde detrás" (Vicente, 2016)

\section{Acústica}

\section{- Acústica en espacios abiertos}

En los espacios abiertos el fenómeno preponderante es la difusión del sonido. La acústica habrá de tener esto en cuenta, para intentar mejorar el acondicionamiento de los enclaves de los escenarios para aprovechar al máximo sus posibilidades y mirar como redirigir el sonido, focalizándolo en el lugar donde se ubique a los espectadores.

"Los griegos construyeron sus teatros, donde las obras dramáticas y las actuaciones musicales, en espacios al aire libre (espacios abiertos) y aprovecharon las propias gradas en donde se ubicaban los espectadores (gradas escalonadas con paredes verticales) como reflectores, logrando así que el sonido reflejado reforzase el directo, de modo que llegaban a cuadruplicar la sonoridad del espacio que quedaba protegido por las gradas". (La acústica y la escena teatral/De la Grecia Clásica al Barroco, s.f.)

"Los romanos utilizaron una técnica parecida, no obstante, la pared de las gradas no era plana, sino curva, lo que permitía que se perdiese menor cantidad de sonido y lo focalizaban mejor hacia un mismo punto (Planteamiento similar al del reflector parabólico)”. (La acústica y la escena teatral/De la Grecia Clásica al Barroco, s.f.) 


\section{- Acústica en espacios cerrados}

En los espacios cerrados, el fenómeno preponderante que se ha de tener en cuenta es la reflexión. Al público le va a llegar tanto el sonido directo como el reflejado, que si van en diferentes fases pueden producir refuerzos y, en caso extremos, falta de sonido.

\section{Escenografía}

"El término, que tiene su origen en un vocablo griego, también permite nombrar al conjunto de los decorados que se utilizan en la representación escénica. También es importante destacar que se habla de un espacio teatral, no de un escenario concretamente, eso quiere decir que una representación teatral se puede hacer en cualquier lugar, sólo hay que saber conjugar los elementos (magnitudes, formas, infraestructura, vínculos) de que dispone ese espacio escénico, las necesidades y carácter de la obra que se representa". (Gómez García, 1997)

\section{Espacio Público}

Se conocen plazas al aire libre o anfiteatros, los cuales están destinados al espectáculo artístico. Estos espacios no cuentan con una reglamentación o normativa establecida, sino por el contrario, tiene un uso flexible. Sirven como interacción con el público haciendo del teatro participativo una forma alternativa de aprendizaje en la denuncia y la intervención social. 


\section{DANZA}

\section{A. HISTORIA Y ANTECEDENTES}

Los orígenes de la danza se pierden en el tiempo, ya que en su vertiente ritual y social ha sido un acto de expresión inherente al ser humano, al igual que otras formas de comunicación como las artes escénicas, o incluso las artes plásticas, como se demuestra por las pinturas rupestres. El baile y la danza han sido un acto de socialización en todas las culturas, realizado con múltiples vías de expresión. Por su carácter efímero resulta prácticamente imposible situar su origen en el espacio y en el tiempo, ya que solo es conocido por testimonios escritos o artísticos (pintura y escultura), los cuales comienzan con las civilizaciones clásicas (Egipto, Grecia, Roma). Por otro lado, desde tiempos antiguos ha existido una dicotomía entre danza como expresión folclórica y popular y la danza como arte y espectáculo, integrado en un conjunto formado por la propia danza, la música, la coreografía y la escenografía. Parece ser que fue en la Antigua Grecia cuando la danza empezó a ser considerada como arte, el cual se representaba frente a un público. En tiempos más modernos, la consideración de la danza como arte — más propiamente llamado ballet- comenzó en el Renacimiento, aunque la génesis del ballet moderno cabría situarla, más bien, en el siglo XIX con el movimiento romántico. (Abad Carlés, 2004)

\section{B. GÉNEROS, ESTILOS Y TENDENCIAS}

\section{Géneros}

- Clásicos:

Principalmente llevan movimientos y elementos armoniosos, suaves y coordinados:

Ballet / Danza Medieval, Barroca, Renacentista / Danza contemporánea / Ballet contemporáneo 
- Folclóricos:

Las danzas folclóricas son danzas que por lo general pertenecen a la cultura y etnia de una región, país o comunidad y pertenecen a la cultura popular:

Bailes de salón / Tango / Danza árabe / Baile de las cintas / Diablada / Marinera / Danza Griega / Danza Azteca / Flamenco / Chacarera / Cumbia / Joropo, entre otras.

- Modernos:

La danza moderna es una expresión corporal artística que nace de la interpretación y visión del bailarín o coreógrafo. Sus movimientos son una expresión libre y fluida de estados, emociones, metáforas o ideas abstractas.

La danza moderna rompe con las reglas y criterios del ballet clásico. No sigue pasos ni movimientos estructurados de antemano. Algunas de ellas son:

Hip Hop / Jazz / Breakdance / Krump / Salsa / Rock n' Roll / Moonwalk / Popping / Hardstep / Hustle / Funky / Jerk / Electro Dance / Pop / K-Pop

\section{$\underline{\text { Estilos }}$}

- Coreografías, Danzas típicas, Improvisaciones y Danza Aérea (telas)

\section{$\underline{\text { Tendencias }}$}

- Dentro de la danza contemporánea podemos encontrar: Hip hop, Break dance, entre otros. (Gómez García, 1997)

\section{ESPACIO ARQUITECTÓNICO EN LOS SALONES DE DANZA}

La arquitectura y la danza, a pesar de ser disciplinas muy distintas entre sí, tienen una estrecha relación en su visión espacial y su proceso creativo. Ambas trabajan el espacio como materia prima y se complementan en su discurso. El proyecto de arquitectura podría utilizar como herramienta la percepción del espacio de la danza, por ejemplo, para mejorar su propia espacialidad. 


\section{Espacio de formación}

Correspondiente a todos los espacios donde no existe relación con el público; sino más bien, son espacios de aprendizaje donde el artista es capacitado en su rama para perfeccionar su talento. Aquí se encuentran las aulas, los talleres, los laboratorios especializados y ambiente de formación teórica. Sin embargo, existen espacios como las salas de ensayo, que son espacios personalizados y acondicionados para el aprendizaje teórico-práctico los cuales requieren dimensiones y características diferentes que as aulas tradicionales.

\section{Espacios de difusión}

Correspondiente a los espacios de representación; es decir, los escenarios, los espacios de interacción con el público.

\section{3. Áreas y proporciones}

Ambientes que se requieren y sus características:

- Aulas teóricas comunes con un máximo de 30 a 50 alumnos

- Talleres prácticos grupales para un máximo de 12 a 15 alumnos. Requieren una altura de 5 metros como mínimo, equipada con espejos, piso con rebote, iluminación cenital, ventilación natural. Además, es necesario que cuenten con depósitos para materiales como: colchonetas, telas, barras, entre otros, con camerinos y duchas

- Laboratorios especializados en proyección de videos, ya que es por este medio que el aprendizaje es de carácter primordial

- Estudios de grabación y/o video

- Salas de ensayo flexible que sirvan para desarrollar todos los géneros de la danza, por ejemplo, acrobacias y danza aérea (telas). Estos últimos determinan una gran altura en los espacios de ensayo que como mínimo debe ser de doble a triple altura. Estos espacios deben tener todos los requerimientos de los talleres prácticos; y además, los techos deben tener una parrilla a la cual se pueda adherir los soportes para las telas en la danza aérea. (Neufert, 2013) 
Proporciones

- De 8 a 9m2 por persona para que realice cualquier actividad corporal de movimiento

- Las barras utilizadas en el ballet deben estar separadas $20 \mathrm{~cm}$ del muro y a una altura de $1.10 \mathrm{~m}$ o $1.30 \mathrm{~m}$

- El suelo debe de ser de preferencia de madera y debe estar aislado del suelo 40 $\mathrm{cm}$

- Uso del linóleo para evitar lesiones en los bailarines.

- Los salones destinados a la enseñanza teórico-práctica de la danza debe contar con aislamiento acústico. (Neufert, 2013)

\section{Iluminación escénica}

El diseño de la iluminación es un aspecto importante para completar el mensaje del coreógrafo. Con los diseños se dan sensaciones; con la iluminación se comunica el colorido, se da la atmósfera a la escena y se guía el interés del público hacia la parte esencial de la danza: bailarines, cuerpos, vestuario y movimientos. La iluminación forma parte de la interpretación de una obra coreográfica.

"La iluminación, de acuerdo a:

- El ballet clásico tradicional, resalta la técnica y la historia

- Danza contemporánea, resalta la idea de comunicar los ambientes, las sensaciones, una idea

- Danza de entretenimiento, como el jazz, el tap, utilizan iluminación diferente

- Danza folklórica, pueden ser rituales, sociales o festivas

- La pantomima, las artes marciales y las gimnásticas, tienen una función estética" (La iluminación en la danza, s.f.) 


\section{$\underline{\text { MÚSICA }}$}

\section{A. HISTORIA Y ANTECEDENTES}

Dado que toda cultura conocida ha tenido alguna forma de manifestación musical, la historia de la música abarca a todas las sociedades y épocas, y no se limita, como ha venido siendo habitual a Occidente, donde se ha utilizado la expresión "historia de la música" para referirse a la historia de la música europea y su evolución en el mundo occidental.

La música de una cultura está estrechamente relacionada con otros aspectos de la cultura, como la organización económica, el desarrollo técnico, la actitud de los compositores y su relación con los oyentes, las ideas estéticas más generalizadas de cada comunidad y la visión acerca de la función del arte en la sociedad, así como las variantes biográficas de cada autor. En su sentido más amplio, la música nace con el ser humano, y ya estaba presente, según algunos estudios, mucho antes de la extensión del ser humano por el planeta, hace más de 50000 años. Es por tanto una manifestación cultural universal. (Nils Lennart Wallin, 2001)

\section{B. EVOLUCIÓN DE LA MÚSICA}

\section{- Edad Media (400-500)}

Destinado a actividades ceremoniales y religiosas o actividades sociales. Aparición del canto gregoriano.

\section{- La liberación del renacimiento (1450-1600)}

Música destinada a los palacios de los reyes y a las cortes y había música vocal, instrumental y danzas cortesanas. El enfoque cambia de religioso a profano.

\section{- El Florecimiento Barroco (1600-1750)}

La música buscaba la perfección y se convirtió en la edad de oro de la música. Además, tenga el carácter que tenga, no perdía su carácter ceremonioso. 
- El ideal Clásico (1750-1810)

Música clara, simple organizada y simétrica. Los músicos pasan de ser esclavos a trabajadores por encargo. Aparición de la ópera, el piano y el clarinete.

\section{- La Expansión Romántica (1810-1910)}

Músicos expresaban sus composiciones en ideales de libertad, sus sentimientos y sus emociones. El instrumento preferido era el piano y aparecieron las orquestas sinfónicas. Inspiraciones en romances medievales, lugares exóticos, etc.

\section{- La exploración del Siglo XX}

Aparición del jazz, donde destacan instrumentos como el saxo, la guitarra, la trompeta, entre otros. Experimentación del sonido a partir de sonidos de la vida cotidiana como maquinas, ruidos ambientales, etc. (Nils Lennart Wallin, 2001)

\section{METODOLOGÍA DE ENSEÑANZA}

- Metodología ORFF. Introduce instrumentos de percusión en los niños y relaciona el lenguaje con el ritmo musical, así como la prosodia o recitados rítmicos. Desarrolla la escala pentatónica y profundiza en el estudio de los sonidos según la secuencia SOL, MI, LA, DO, RE. Su teoría otorga mucha importancia a la improvisación, a la creatividad y al hacer, sin embargo, su metodología no abarca ni profundiza el estudio del canto.

- Metodología KODALY. Introdujo la fonomia, trabaja el canto y la altura relativa de los sonidos. Convierte las notas musicales en números romanos refiriéndose a grados. Logra que los niños interioricen las distancias, y puedan cantas en toda la tonalidad. El elemento principal para kodet, es el canto.

- Metodología alcorce. Es el creador de la rítmica, el cual permite adquirir un sentido musical mediante el ritmo del cuerpo. Halló una pedagogía del gesto, sobre el inicio del movimiento. La música comunica al cerebro una imagen que da origen al movimiento, donde, si la música fue bien percibida, esto dará lugar a una expresión corporal. (Ministerio de Educacion de Argentina, s.f.) 


\section{ESPACIOS ARQUITECTÓNICOS EN LOS SALONES DE MÚSICA}

\section{Espacios de formación (salones)}

En los espacios cerrados, el fenómeno preponderante que se ha de tener en cuenta es la reflexión. Al estudiante le va a llegar tanto el sonido directo como el reflejado, que si van en diferentes fases pueden producir refuerzos y en caso extremos falta de sonido. A la hora de acondicionar un local, se ha de tener en cuenta, tanto que no entre el sonido del exterior. (Arau, 2007)

\section{Espacios de difusión (anfiteatros, plazas)}

En los espacios abiertos el fenómeno preponderante es la difusión del sonido. Las ondas sonoras son ondas tridimensionales, es decir, se propagan en tres dimensione y sus frentes de ondas son esferas radiales que salen de la fuente de perturbación en todas las direcciones. La acústica habrá de tener esto en cuenta, para intentar mejorar el acondicionamiento de los enclaves de los escenarios para aprovechar al máximo sus posibilidades y mirar como redirigir el sonido, focalizándolo en el lugar donde se ubique a los espectadores. (Arau, 2007) 


\subsection{Metodología de enseñanza colaborativa para las artes}

Algunos psicólogos y psicopedagogos consideran el aprendizaje colaborativo como un método de aprendizaje a través del cual los alumnos aprenden mediante la interacción entre iguales, teniendo todos los miembros del grupo la misma función de liderazgo y la misma responsabilidad en la consecución del aprendizaje. El profesor cambia su rol en este tipo de aprendizaje, pasa de enseñar a guiar en el proceso, ya que son los alumnos quienes consiguen llegar a conclusiones propias a partir de sus actividades en común. Esta forma de aprendizaje, elimina el elemento competitivo de las actividades, ya que la meta que se persigue es común a todos los alumnos, de la calidad del trabajo de cada miembro, depende el resultado para todo el grupo. (Martín, 2012)

\section{Organizar los estudiantes en parejas o en equipos pequeños.}

Como se mencionó anteriormente, el aprendizaje colaborativo se basa en la conformación de parejas o equipos pequeños de trabajo en aula de clase o taller, y el éxito de esta metodología depende en gran manera de la conformación de éstos. Hay autores que plantean que los grupos pueden formarse al azar, o por decisión de los estudiantes o del profesor. Pero la práctica y trabajo constante demuestra que los mejores resultados se logran en equipos heterogéneos y conformados por el profesor; para crear los equipos el profesor puede hacer un rastreo de los conocimientos previos de sus estudiantes con ayuda de entrevistas, cuestionarios o dinámicas de grupo y en base a estos decidir cómo conformar las parejas o los equipos con balance, variedad y compatibilidad dependiendo del proyecto a realizar. (Martín, 2012)

\section{Roles y responsabilidades del profesor y los estudiantes.}

En el aprendizaje colaborativo el profesor debe balancear la exposición y las demostraciones de la clase con los proyectos propuestos a los estudiantes. El profesor no puede ser sólo la persona que brinda instrucciones o que habla dentro del taller, la función del profesor debe ser la de guía y de un co-investigador activo y constante de la técnica, ya que los procesos químicos constantemente plantean nuevos retos tanto para él como para sus estudiantes, de esta manera el profesor debe estar siempre observando los 
proyectos de cada equipo haciendo sugerencias acerca del cómo proceder y dónde encontrar las solución a los problemas que plantea el proceso litográfico.

Se ha utilizado el aprendizaje colaborativo por la ampliación teórica y técnica de la información y con esto se puede encontrar una manera de romper las barreras formales y además ejercer los roles de artista o impresor. A través de esta experiencia que los estudiantes mejoran la calidad de sus trabajos artísticos, también su capacidad de diálogo y el pensamiento creativo a partir de la colaboración con terceros. Por último, la vida laboral del artista educador se ve mejorada por la condición de su trabajo en grupo y la investigación de problemas a los cuales no se había enfrentado tanto desde el rol de estudiante como del profesor. (Martín, 2012)

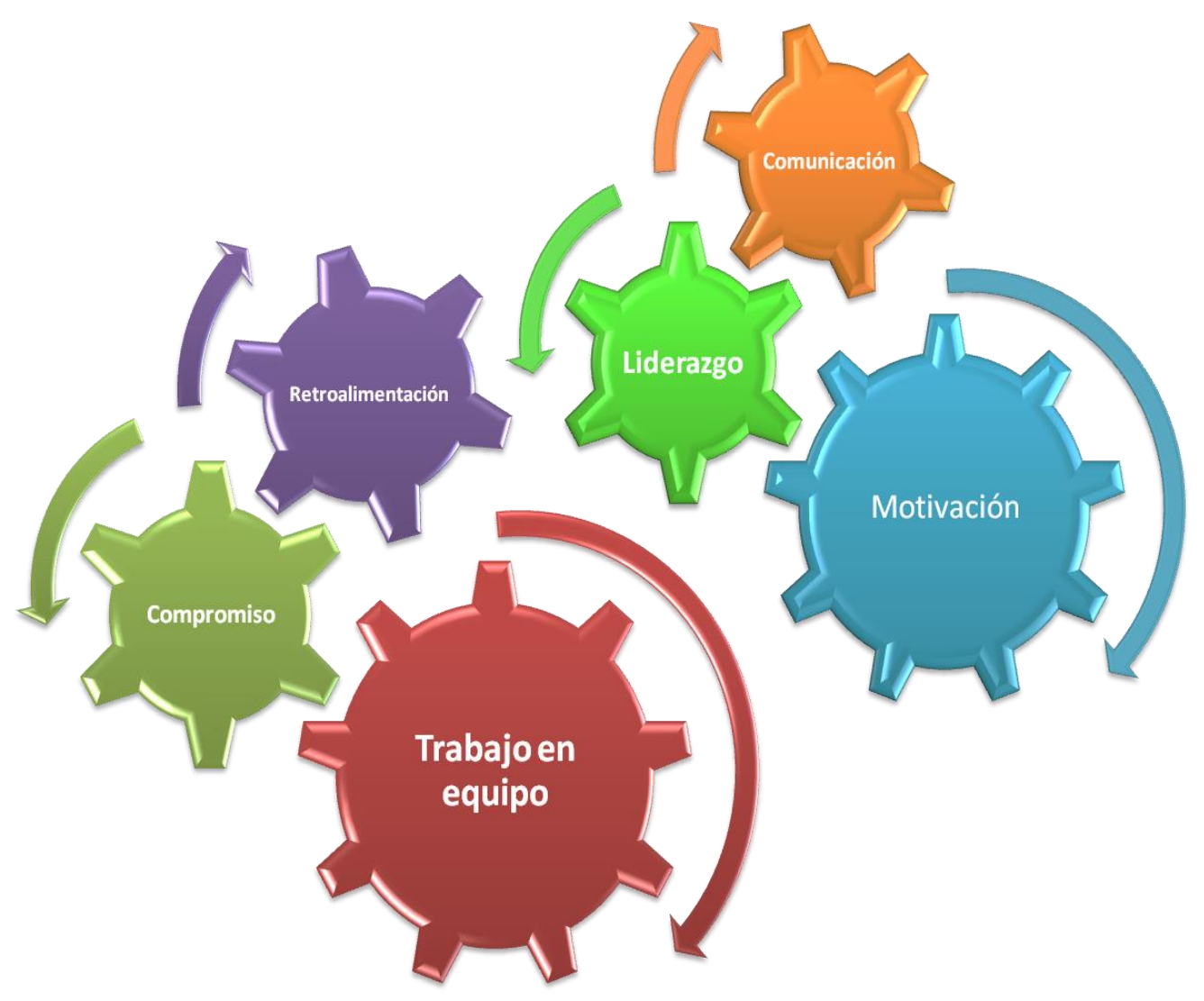

Fig. 6: Diagrama Enseñanza colaborativa

http://estrategaprendizaje.blogspot.pe 


\subsection{Demanda de la educación artística en el Perú}

Tabla 1: Cuadro de escuela de artes más conocidas en el Perú

\begin{tabular}{|c|c|c|c|c|c|}
\hline Nombre & Nivel/Modalidad & Gestión/Dependencia & Dirección & Departamento/Provincia/Distrito & Alumnos(2013) \\
\hline $\begin{array}{l}\text { ANTONIO RUIZ DE } \\
\text { MONTOYA }\end{array}$ & $\begin{array}{l}\text { Educación Superior } \\
\text { Artística - ESFA }\end{array}$ & Privada - Particular & $\begin{array}{l}\text { Av. Paseo de } \\
\text { los Andes } 970\end{array}$ & Lima / Lima / Pueblo Libre & -- \\
\hline $\begin{array}{l}\text { ARTE DRAMÁTICO } \\
\text { GUILLERMO UGARTE } \\
\text { CHAMORRO }\end{array}$ & $\begin{array}{c}\text { Educación Superior } \\
\text { Artística - ESFA }\end{array}$ & $\begin{array}{l}\text { Pública - Sector } \\
\text { Educación }\end{array}$ & $\begin{array}{l}\text { Av. } 28 \text { de Julio } \\
\text { S/N }\end{array}$ & Lima / Lima / Lima & -- \\
\hline BELLAS ARTES DEL PERÚ & $\begin{array}{l}\text { Educación Superior } \\
\text { Artística - ESFA }\end{array}$ & $\begin{array}{l}\text { Pública - Sector } \\
\text { Educación }\end{array}$ & Jr. Ancash 681 & Lima / Lima / Lima & -- \\
\hline JOSE MARIA ARGUEDAS & $\begin{array}{l}\text { Educación Superior } \\
\text { Artística - ESFA }\end{array}$ & $\begin{array}{l}\text { Pública - Sector } \\
\text { Educación }\end{array}$ & Jr. Ica 143 & Lima / Lima / Lima & -- \\
\hline $\begin{array}{l}\text { MUSICA JOSAFAT ROEL } \\
\text { PINEDA }\end{array}$ & $\begin{array}{l}\text { Educación Superior } \\
\text { Artística - ESFA }\end{array}$ & Privada - Particular & $\begin{array}{l}\text { Av. Alejandro } \\
\text { Bertello } 1092\end{array}$ & Lima / Lima / Lima & -- \\
\hline $\begin{array}{l}\text { ARTE NEGOCIOS Y } \\
\text { TECNOLOGIA ESANTEC }\end{array}$ & $\begin{array}{l}\text { Educación Superior } \\
\text { Artística - ESFA }\end{array}$ & Privada - Particular & $\begin{array}{l}\text { Av. Arenales } \\
2341\end{array}$ & Lima / Lima / Lima & 202 \\
\hline $\begin{array}{l}\text { CONSERVATORIO } \\
\text { NACIONAL DE MÚSICA }\end{array}$ & $\begin{array}{l}\text { Educación Superior } \\
\text { Artística - ESFA }\end{array}$ & $\begin{array}{l}\text { Pública - Sector } \\
\text { Educación }\end{array}$ & $\begin{array}{l}\text { Jr. Carabaya } \\
\quad 429\end{array}$ & Lima / Lima / Lima & 180 \\
\hline CORRIENTE ALTERNA & $\begin{array}{l}\text { Educación Superior } \\
\text { Artística - ESFA }\end{array}$ & Privada - Particular & $\begin{array}{l}\text { Ca. Renan } \\
\text { Elias } 500\end{array}$ & Lima / Lima / Miraflores & 115 \\
\hline NACIONAL DE BALLET & $\begin{array}{l}\text { Educación Superior } \\
\text { Artística - ESFA }\end{array}$ & $\begin{array}{l}\text { Pública - Sector } \\
\text { Educación }\end{array}$ & $\begin{array}{l}\text { Ca. Spencer } \\
\text { Mz O Lote } 2\end{array}$ & Lima / Lima / Surquillo & 37 \\
\hline $\begin{array}{l}\text { THEODORO VALCARCEL } \\
\text { CABALLERO }\end{array}$ & $\begin{array}{c}\text { Educación Superior } \\
\text { Artística - ESFA }\end{array}$ & Privada - Particular & $\begin{array}{c}\text { Av. Las Torres } \\
349\end{array}$ & Lima / Lima / Ate & 32 \\
\hline
\end{tabular}

Estas últimas Escuelas de Arte actualmente están activas. (Díaz, Juan José, 2006)

Han surgido nuevas oportunidades académicas para poder estudiar el arte escénico tanto de manera clásica como moderna o contemporánea, de tal modo que algunas universidades han incluido una facultad de artes escénicas, teniendo entre sus carreras: la música, la danza y el teatro, con una enseñanza personalizada y hacia la tendencia moderna. En el siguiente punto, se hablará acerca de este tema. 


\subsection{Oportunidades en el campo}

\subsubsection{Oportunidades estudiantiles}

Actualmente, en Lima, existen institutos o escuelas superiores del arte escénico que brindan carreras de bachiller a los alumnos interesados en las ramas del arte escénico. Estas escuelas nacionales superiores tienen una enseñanza destinada más al ámbito clásico. Entre ellas tenemos: Escuela Nacional de Arte Dramático de Lima, Conservatorio Nacional del Perú y Escuela Superior de Ballet.

Sin embargo, desde hace ya un tiempo atrás, las universidades como la PUCP, UPC, UCSUR, entre otras, han incluido la facultad de artes escénicas a la lista de sus carreras universitarias, brindando una carrera profesional de 5 años, obteniendo un título profesional a nivel nacional. (Facultad de Artes Escénicas de la PUCP, s.f.)

\subsubsection{Oportunidades laborales}

\section{Teatro}

- Compañías profesionales de teatro

- Productoras de radio, cine y televisión

- Centros de enseñanza media y superior

- Centros culturales e instituciones dedicadas a la difusión de la cultura

- Crítica teatral

\section{Música}

- Ejecución musical como solista, en grupos u orquestas

- Composición musical para solitas, grupos y orquestas

- Creación de música para películas, televisión y teatro

- Gestión y manejo de estudios de grabación

- Realización de espectáculos musicales

- Producción ejecutiva para la industria discográfica

- Elaboración de proyectos musicales para agencias de publicidad 
- Desarrollo de productos musicales en ámbitos multimedia e internet

- Educación musical y artística en colegios, institutos y universidades

- Investigación musical desarrollada en institutos, universidades y entidades privadas

\section{Danza}

- Grupos de danza contemporánea o de teatro

- Instituciones o asociaciones de estudio, producción e investigación de danza contemporánea

- Instituciones educativas (colegios y/o universidades)

- Instituciones de proyección social

\subsection{Importancia de la educación artística en el Perú}

\section{¿Por qué es importante la educación por el arte en los colegios del Perú?}

Los participantes del curso de Práctica Pre Profesional de Educación Artística de la especialidad de música, de la Escuela Nacional Superior de Folklore José María Arguedas, ensayan algunas respuestas a esta interrogante. (Prof. Francisco Caro, 2015)

- La creatividad y sensibilidad, que son reforzadas en gran manera a través del arte y que no son sólo necesarias para desarrollarse artísticamente, sino que la creatividad es requerida en muchos aspectos de la vida para desarrollar problemas.

- El arte, en sus diferentes expresiones, permite desarrollar las capacidades comunicativas.

- Todo ser humano tiene la necesidad de expresión, plasmar sus emociones y a su vez estas expresiones sirven para comprender el proceso histórico y sociocultural de una sociedad.

La educación artística a temprana edad también repercute en la generación de personas cultas en el arte, aunque estas personas no se dediquen a él, pueden ser futuros espectadores del arte.

"La mayoría de los niños que aprovechan una formación teatral en la escuela no serán ni pretenden ser nunca actores. Sin embargo, esta mayoría será probablemente un público 
más experimentado, experto, sensible a la oferta cultural, crítico frente a su funcionamiento social. En esta medida, habrán sido preparados para ser no solamente individuos, sino sujetos miembros de una colectividad, con capacidad participativa y renovadora. La educación teatral aporta una formación integral a los sujetos, a la vez corporal, sensitiva, intelectual y espiritual; y esto lo hace a partir del grupo como núcleo de individuación mediante el cual los alumnos aprenderán a ser parte de la sociedad en la que se desenvuelven, sin por ello sacrificar su propia subjetividad." (Carolina Merchan Price, 2014)

\subsection{Términos - Glosario}

\section{ACCIÓN DRAMÁTICA}

Conjunto de acciones de los personajes que giran en torno al conflicto dramático. La acción es el elemento transformador y dinámico por antonomasia, que permite pasar, lógica y temporalmente, de una situación a otra permitiendo el avance de una obra.

\section{ACTO}

Corresponde a la unidad mayor en que se divide una obra dramática. Los actos suelen estar separados entre sí por un momento de oscuridad o una pausa marcada por el cierre del telón. Tradicionalmente una obra se divide en tres actos que coinciden con la presentación, desarrollo y desenlace de conflicto. Cada acto se compone de cuadros (coincide con los cambios de escenografía) y escenas (marcada por la entrada y salida de personajes del escenario).

\section{ACTOR}

El que hace una profesión de representar obras dramáticas.

\section{ANTAGONISTA}

Personaje opuesto al protagonista de la obra. 


\title{
ARGUMENTO
}

Se denomina argumento al contenido esencial y sintético de una obra teatral. En general, el argumento puede ser dado a conocer antes de la obra para informar acerca de la historia que será presentada y suscitar interés en los posibles espectadores.

\begin{abstract}
ARQUETIPO
Un arquetipo (del griego arjé, “origen”, y typos, “modelo") es el patrón ejemplar del cual otros objetos, ideas o conceptos se derivan. En referencia a la obra dramática se utiliza para denominar un personaje, motivo, símbolo o tema que aparece frecuentemente a través de diferentes períodos literarios y que se convierte en un elemento reconocido, en un tipo universal o tradicional. Por ejemplo: don Juan, La Madre Tierra, etc.
\end{abstract}

\section{BAMBALINA}

Pieza de tela o papel que cuelga de un lado a otro del escenario de un teatro evitando que el público vea lo que hay entre ellas y el telar (estructura de la parte superior del escenario de un teatro que permite subir y bajar los telones escenográficos). Dícese "tras bambalinas" para denominar todo aquello que sucede detrás del escenario durante la representación de un espectáculo, fuera de la vista del espectador.

\section{CARACTERIZACIÓN}

La RAE define caracterizar como determinar los atributos peculiares de algo o alguien, de modo que se distinga claramente de los demás. En referencia a las artes escénicas se utiliza específicamente para hablar de la adecuación de un actor con respecto a los rasgos físicos del personaje que debe interpretar, por medio del uso de maquillaje y vestuario. El proceso se complementa con las acciones, palabras y pensamientos del actor.

\section{COMEDIA DEL ARTE}

Género teatral de carácter popular que surge en Italia en el siglo XVI, caracterizado por la actuación al improviso de los actores. Los personajes suelen ser siempre los mismos, sólo varían los argumentos que suelen ser enredos amorosos. En la Comedia del Arte, todos los personajes usan media máscara (que permite al comediante hablar) exceptuando a los enamorados. 


\section{DIÁLOGO}

Conversación entre dos o más personajes.

\section{DIRECTOR}

Es la mayor autoridad en el marco del montaje de una obra de teatro. Es su visión conceptual y espacial la que se refleja en la presentación y tiene bajo su cargo a los directores técnicos y a los actores. El director puede ser o no ser el autor de la obra que dirige.

\section{DRAMA}

Drama proviene del griego y significa "hacer" o "actuar". Esta palabra se utiliza para denominar el género de la creación literaria que ha sido escrito con el objetivo de ser representado públicamente en un espacio escénico. El teatro es la concreción del drama y encarna algún episodio o conflicto de la vida de los seres humanos por medio del diálogo entre los personajes.

\section{DRAMATURGO}

Escritor o autor de obras dramáticas.

\section{ELENCO}

Conjunto de artistas que forman la compañía y, en particular, quienes participan en la obra que se va a presentar.

\section{EMBOCADURA O BOCA}

Abertura del escenario que permite al público ver la escena. La embocadura define límite imaginario que separa el espacio escénico de la sala donde está el público.

\section{ENSAYO}

Representación de la obra que se realizan varias antes de la representación al público como prueba o preparación. Además del elenco participa el equipo de técnicos. 


\section{ENSAYO GENERAL}

Último ensayo antes del estreno y se realiza con vestuario, maquillaje, iluminación, sonido y decorados. Algunas compañías invitan familiares y cercanos para hacer un ensayo con público.

\section{ENTREACTO}

Espacio de tiempo entre un acto y otro.

\section{ESCENARIO}

Espacio físico destinado a la representación de la obra de teatro (u otras artes escénicas). Existen diversas tipologías de escenarios.

\section{ESCENOGRAFÍA}

Es el diseño y la organización del escenario por medio de un conjunto de elementos necesarios para recrear un lugar y un momento determinado para la obra, así como su ambiente o atmósfera.

\section{ESCENÓGRAFO}

Persona que se encarga de diseñar y realizar la escenografía. En algunos casos, además de realizar esta función, asume el diseño del vestuario y la iluminación.

\section{EXPERIENCIA ARTÍSTICA}

Modo de encuentro sensible con el mundo, que produce en quien lo experimenta un placer, un conjunto de emociones y un tipo de conocimiento de índole estética. A diferencia de otras experiencias tiene una finalidad en sí misma y es desinteresada de aspectos prácticos. La experiencia estética supone una aproximación sensible, activa y de recepción del fenómeno artístico.

\section{FORO}

Parte del escenario opuesto a la embocadura y la más distante del público. 


\section{FOSO}

Espacio situado a nivel inferior del escenario, ubicado entre éste y la sala para el público, que se utiliza principalmente para instalar la orquesta o músicos en ciertos espectáculos (ópera, ballet, entre otros). También puede ser utilizado para guardar piezas de utilería.

\section{ILUMINADOR}

Persona que trabaja junto al escenógrafo para ambientar con luces las escenas.

\section{JUGLAR}

Artista de la entretención, típico de la Europa Medieval. Su trabajo artístico incluía la declamación, la música instrumental, el canto, el baile, los malabares y otros ejercicios circenses.

\section{MONÓLOGO}

Parlamento en que habla un actor/actriz que está solo en escena. Puede dirigirse a sí mismo o a otra persona.

\section{PAPEL O ROL}

Personaje que representa un actor en una obra.

\section{PARLAMENTO}

Líneas o párrafos que se le asigna a un actor para la representación de una obra.

\section{PERSONAJE}

Personas o seres conscientes (humanos, animales, dioses o de cualquier tipo) que aparecen en una obra o que existen dentro del universo de una obra. Se trata de una construcción mental elaborada mediante la imagen y el lenguaje.

\section{PRODUCTOR TEATRAL}

Responsable de la administración de una compañía y/o de llevar a cabo la supervisión total del montaje de una obra teatral. Se encarga de la búsqueda y distribución de fondos, contratación de personal y supervisión de todos los aspectos propios de la producción. Las grandes realizaciones pueden requerir varios productores, organizados como productor ejecutivo y asociado, o coproductores, cada uno de los cuales se encarga de una parte de la producción. 


\section{SALA}

Espacio físico donde se sitúa el público durante el espectáculo.

\section{TROVADOR}

Poeta medieval popular. Sus trovas, a diferencia de la del juglar, eran elaboradas y cultas, de tema generalmente amoroso y dedicado a reyes, nobles y grandes señores.

\section{UTILERÍA}

Todos los artículos y objetos que aparecen es escena. Junto con la escenografía y la vestimenta, forma parte de los recursos necesarios para la representación teatral.

\section{VANGUARDIA}

Referido a los movimientos o corrientes artísticas, grupos, personas, etc., partidarios de la renovación, avance y exploración en el campo literario, artístico, político, ideológico, etc.

(Educación Cultura, Glosario de Teatro, 2012) 


\section{CAPÍTULO III - Marco conceptual}

\section{1 Énfasis: "relación y organización espacial capaz de estimular nuevas situaciones y entornos para el aprendizaje"}

Teniendo en cuenta los espacios que requieren en los ambientes tanto teatro, danza y música, se agrupan los cinco tipos de ambiente que comúnmente existen en estas tres ramas.

Como se mencionó anteriormente, el énfasis de éste tema de investigación es la "relación

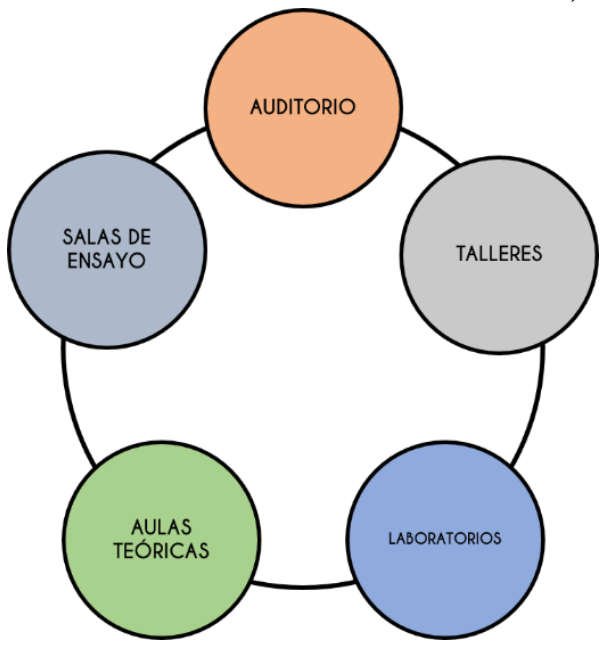

Fig. 7: Diagrama. Elaboración propia y organización espacial capaz de estimular nuevas situaciones y entornos para el aprendizaje".

Lo que se quiere lograr a través de este estudio es una relación entre el espacio intermedio o conector con las clases de teoría o práctica elaborando secuencias espaciales que unifiquen la enseñanza. Es decir, fuera de estos cinco espacios crear ambientes de interacción educativa ya que la enseñanza no es solo en los salones, sino fuera de ellos por medio de vínculos sociales entre estudiantes. (Herman Hertzberger, 2010)

Podemos concluir que estos espacios se dividen en: espacios específicos para la formación de cada rama artística y espacios de difusión de todas las ramas (teatro, música y danza).

Fig. 8: Diagrama de espacios. Elaboración propia

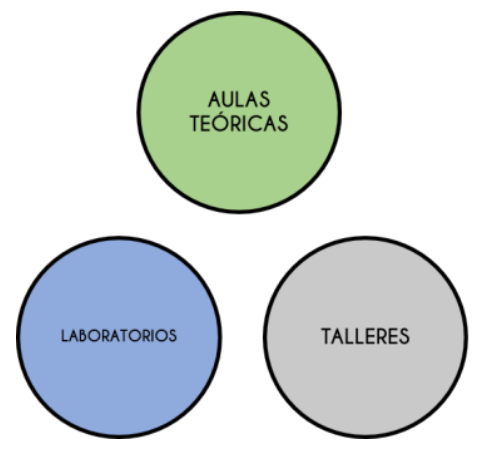

Espacios específicos para la formación de cada rama artística

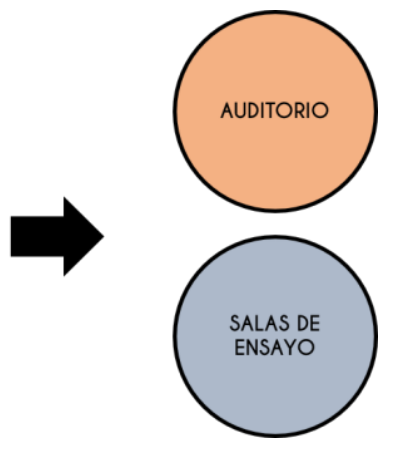

Espacios de difusión de todas las ramas (teatro, música y danza) 


\subsection{Tipos de relación espacial}

Espacio dentro de

otro espacio

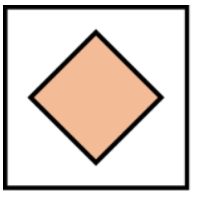

Espacios conectados

entre sí

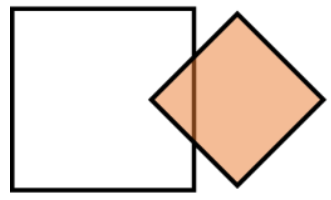

Espacios continuos

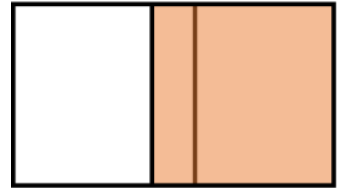

Espacios vinculados

por uno en común

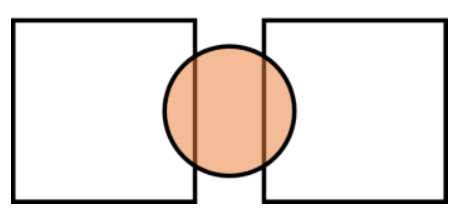

Fig. 9: Relación espacial /Elaboración propia

Fuente: (D. K. Ching, 2012)

\subsection{Organización espacial}

Organización central

Organización lineal

Organización radial

Organización agrupada

Organización en trama

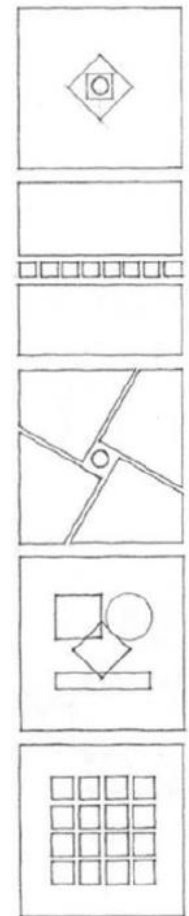

Fig. 10: Organización espacial/Elaboración propia Fuente: (D. K. Ching, 2012) 


\subsection{Edificio Cultural}

“...que la cultura da al hombre la capacidad de reflexionar sobre sí mismo. Es ella la que hace de nosotros seres específicamente humanos, racionales, críticos y éticamente comprometidos. A través de ella discernimos los valores y efectuamos opciones. A través de ella el hombre se expresa, toma conciencia de sí mismo, se reconoce como un proyecto inacabado, pone en cuestión sus propias realizaciones, busca incansablemente nuevas significaciones, y crea obras que lo trascienden”. (UNESCO, 1982)

No obstante, podemos entender cultura como el "conjunto de modos de vida y costumbres, conocimientos y grado de desarrollo artístico, científico, industrial, en una época, grupo social, etc.” (UNESCO, 1982)

Un edificio cultural es aquel edificio, de carácter público o privado, destinado a difundir conocimiento, sabiduría y cultura.

\subsection{Borde}

Según Kevin Lynch, el espacio urbano está conformado por cinco elementos. El borde es uno de ellos.

"Los bordes son elementos lineales que el observador no usa o considera sendas. Son los límites entre dos fases, rupturas lineales de la continuidad, como playas, cruces de ferrocarril, bordes de desarrollo,...o bien pueden ser suturas, líneas según las cuales se relacionan y unen dos regiones”. (Kevin Lynch, 1998)

Gracias a las tendencias contemporáneas de integrar los edificios de uso público, como es el caso de la Biblioteca de España, están tendiendo a crear espacios abiertos que sirven un punto intermedio entre el borde de las edificaciones privadas y la calle.

\subsection{Espacio intermedio}

"El umbral es la clave de la transición y conexión entre las áreas con exigencias territoriales divergentes y, como un lugar con derecho propio, constituye en esencia, la condición espacial de encuentro y relación entre las zonas de diferentes órdenes." (Herman Hertzberger, 2005) 


\section{CAPÍTULO IV - Proyectos referenciales}

4.1 The Julliard School, Nueva York, Estados Unidos

4. 2. Escuela de diseño de la Univ. De Melbourne, Melbourne VIC, Australia

4. 3. Centro Universitario "des Quais", Lyon, Francia

4. 4. Museo de la memoria y de los derechos humanos, Santiago de Chile, Chile

4.5. Escuela de Diseño e Instituto de Estudios Urbanos Pontificia Universidad Católica de Chile 


\section{CAPÍTULO V - Lugar}

\subsection{Criterios de selección}

Los criterios de selección planteados por el MINEDU para los IESFA (Institutos y Escuelas Superiores de Formación Artística):

\subsubsection{Aspectos generales}

"Los Institutos y Escuelas Superiores de Formación Artística son instituciones que brindan formación inicial docente en el campo artístico o de artista profesional, en diferentes especialidades. Ofrecen, a través de programas autorizados por el Ministerio de Educación, capacitación, actualización y especialización a técnicos, profesionales técnicos y profesionales, asimismo, formación especializada a través de estudios de posttítulo. Además, brindan formación artística temprana en sus diferentes modalidades. La formación temprana no constituye educación superior." (MINEDU, 2010)

La ubicación en donde se emplaza el proyecto debe ser accesible para diferentes distritos como para el propio y que este equipamiento planteado no sea de un uso exclusivo del barrio o del distrito, sino que pueda ser utilizado a nivel interdistrital.

El uso de áreas libres y recreativas en una escuela de artes es importante ya que promueven el desarrollo emocional frente al público o estudiantes de diferentes ramas del arte.

\subsubsection{Aspectos físicos}

\section{- Topografía}

"La pendiente máxima de los terrenos debe ser de 15\% de longitud en cualquier sentido; en el caso de que las pendientes sean mayores, el adquirente debe presentar un proyecto de aterrazamiento, relleno o re nivelación que permita aprovechar al menos el $90 \%$ de la 
superficie del predio" (Convenio de Cooperación Interinstitucional: MINEDU-UNIFAUA, 2006)

Los terrenos deberían tener formas regulares, sin entrantes ni salientes, de perímetros definidos y mensurables, la relación entre sus lados como máximo debe ser de 1 a 2 cuyos vértices en lo posible sean hito de fácil ubicación y permanentes que permitan su registro. (Convenio de Cooperación Interinstitucional: MINEDU-UNI-FAUA, 2006)

\section{- Criterios accesibilidad}

Algunos criterios en la elección del terreno:

- Debe contar con una accesible ubicación de tal manera que pueda ser un hito o una actividad estructurante del lugar donde se encuentre.

- Accesible para todas las personas, sobre todo a los que cuenten con alguna discapacidad física.

- Cercanía a sistema de transporte masivo como la línea 1 del tren eléctrico, metropolitano, o líneas de buses que recorran una gran parte de Lima y a una red de alimentadores.

\section{- Criterio localización y ubicación}

- La ubicación del terreno para una escuela de formación y difusión de artes escénicas debe contar con 2 frentes como mínimo ya que existirán varios ingresos para los diferentes tipos de usuarios.

- Para un futuro buen funcionamiento es recomendable que no esté ubicado en la periferia de la ciudad, sino por el contrario, debe estar ubicado en una zona consolidada.

\section{- Criterio de relación con el entorno: Viabilidad y transporte / uso de suelos}

En base a los proyectos referenciales, los criterios de la relación con el entorno son:

- Entorno con densidad media o alta

- Cercanía a vías principales que conecten extremos de la ciudad

- La ubicación del terreno debe encontrarse integrado a un sistema de centros o conjunto de equipamientos que fortalezcan y complementen el tema propuesto. 


\subsubsection{Aspectos RNE}

- “Las Habilitaciones para Usos Especiales, de acuerdo a su finalidad, podrán llevarse a cabo sobre terrenos ubicados en sectores de Expansión Urbana p que constituyan islas rústicas, con sujeción a los parámetros urbanísticos en el Cuadro Resumen de Zonificación y las Exposiciones del Plan de Desarrollo Urbano" (Artículo 1, Capítulo I, Norma TH.040, TITULO II HABILITACIONES URBANAS, RNE LIMA PERU)

- "Las Habilitaciones para Usos Especiales destinadas a escenarios deportivos, locales recreativos de gran afluencia de público o campos feriales tienen gran impacto en la infraestructura vial, por lo que debe efectuarse estudios de impacto ambiental y/o vial" (Artículo 5, Capítulo II, Norma TH.040, TITULO II HABILITACIONES URBANAS, RNE LIMA PERU)

- "Las habilitaciones para Usos Especiales destinadas a escenarios deportivos, locales recreativos de gran afluencia de público o campos feriales de acuerdo a las características urbanas de la localidad en que se ubican podrán ser del tipo C al A, compatible con los sectores colindantes y la intensidad de uso de vías que concluya el estudio de impacto ambiental y/o vial" (Artículo 8, Capítulo II, Norma TH.040, TITULO II HABILITACIONES URBANAS, RNE LIMA PERU)

- "Los proyectos de edificaciones para recreación y deportes, requieren la elaboración de los siguientes estudios complementarios:

-Estudio de Impacto Vial, para edificaciones que concentren más de 1000 ocupantes.

-Estudio de Impacto Ambiental, para edificaciones que concentren más de 3000 ocupantes." (Artículo 3, Capítulo I, Norma A.100, TITULO III EDIFICACIONES, RNE LIMA PERU)

- “Los proyectos de edificación para recreación y deportes, requieren la elaboración de los siguientes estudios complementarios:

- Facilidad de acceso y evacuación de las personas provenientes de las circulaciones diferenciadas a espacios abiertos

- Factibilidad de los servicios de agua y energía

- Orientación del terreno, teniendo en cuenta el asolamiento y los vientos predominantes 
- Facilidad de acceso a los medios de transporte" (Artículo 4, Capítulo I, Norma A.100, TITULO III EDIFICACIONES, RNE LIMA PERU)

\subsection{Elección del lugar apropiado}

Uno de los objetivos de este tema de investigación era poder descentralizar la difusión de las artes escénicas en la ciudad de Lima. Por tal motivo se investigó que la mayoría de centros culturales y de formación artística se encuentran principalmente en los distritos de Lima, Miraflores y Barranco. (Ministerio de Cultura, 2015) Ver ilustración 13 y 14.

Lima norte cuenta con grandes lotes industriales que actualmente se han vuelto un peligro para los ciudadanos ya que generan muros ciegos perimetrales y que no benefician ningún uso a la ciudad.

\subsection{1. ¿Por qué Lima Norte?}

“Cualquier limeño sabe que Lima bordea los 8 millones de habitantes; sin embargo, son pocos los que saben que la gran mayoría de ellos vive en las zonas periféricas de la ciudad. Por ejemplo, en San Isidro viven unas 45.000 personas, mientras que Los Olivos tiene 800.000 habitantes. Es esta concentración demográfica la que ha convertido a Lima norte (Independencia, Los Olivos, San Martín de Porres, Comas y Carabayllo) en el más importante polo de crecimiento urbano.

Lima norte ha seguido una evolución natural. Empezó como una invasión, luego se consolidó como una ciudad dormitorio y hoy es una de las zonas más grandes que requiere servicios cada vez más sofisticados. Lo que antes era una población que intentaba subsistir se ha convertido en un conglomerado de personas con poder adquisitivo que se niega a trasladarse por horas para acceder a servicios que les corresponden por derecho. Así nacen, por ejemplo, los grandes y modernos centros comerciales que proliferan en la zona actualmente.

Lima norte es la nueva Lima y como tal tiene grandes oportunidades de crecer ordenadamente. Solo basta esperar que las autoridades crean lo mismo." (El Comercio.pe, 2010) 


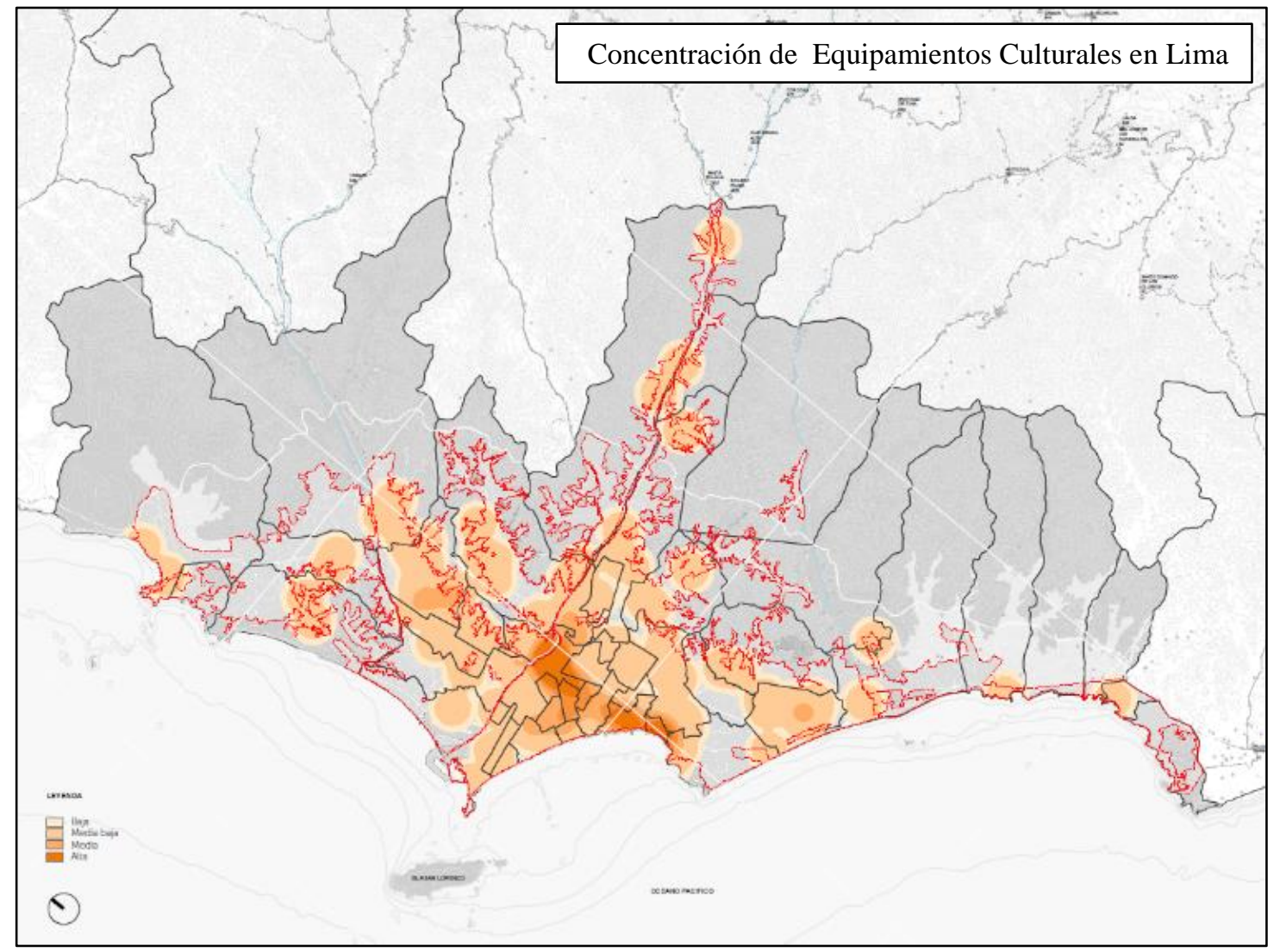

Fig. 11: Mapa de concentración de equipamientos culturales en Lima

Fuente: Plan de Lima 2035

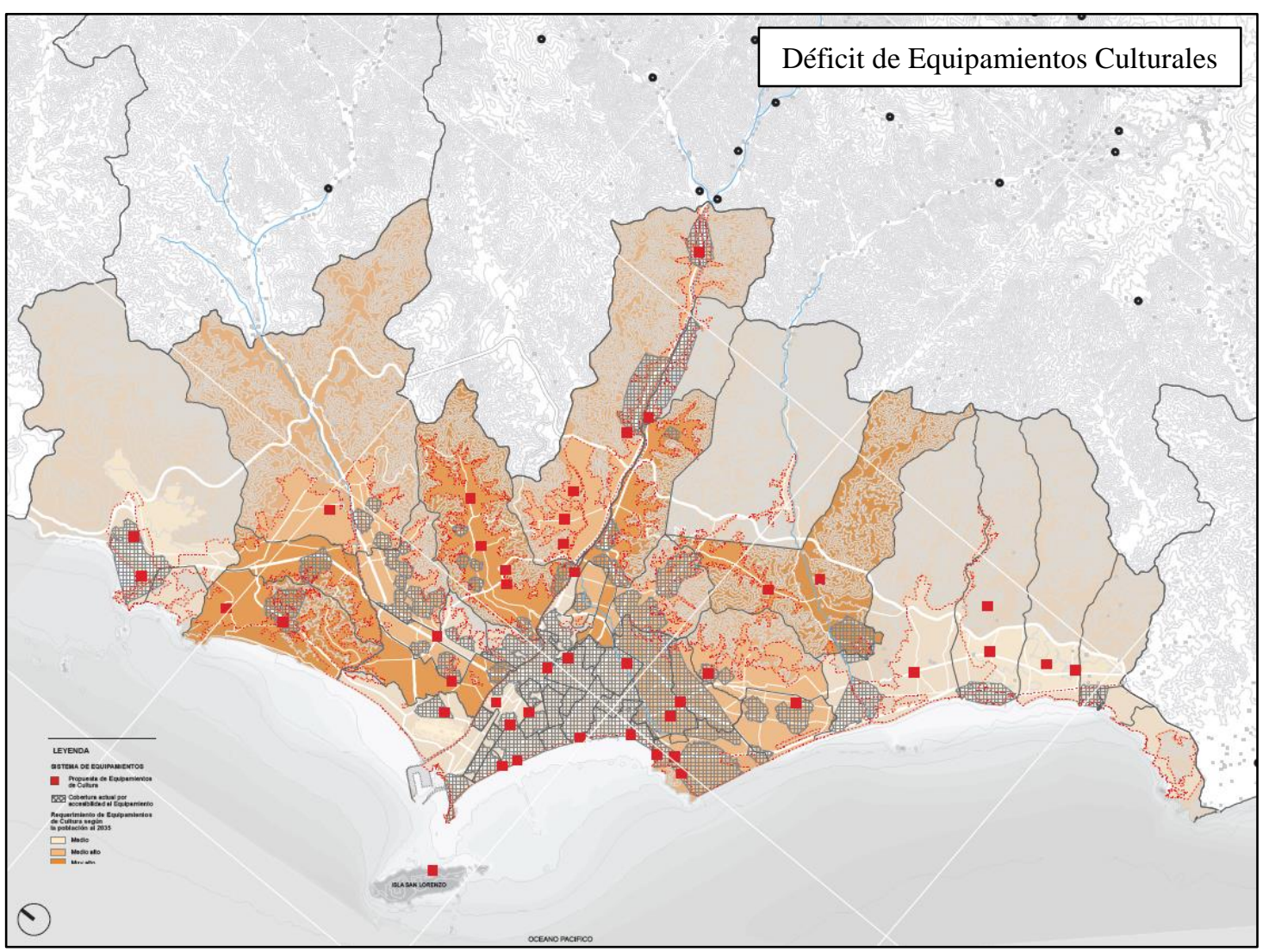

Fig. 12: Mapa déficit de equipamientos culturales 


\subsection{Ficha técnica de Lima Norte}

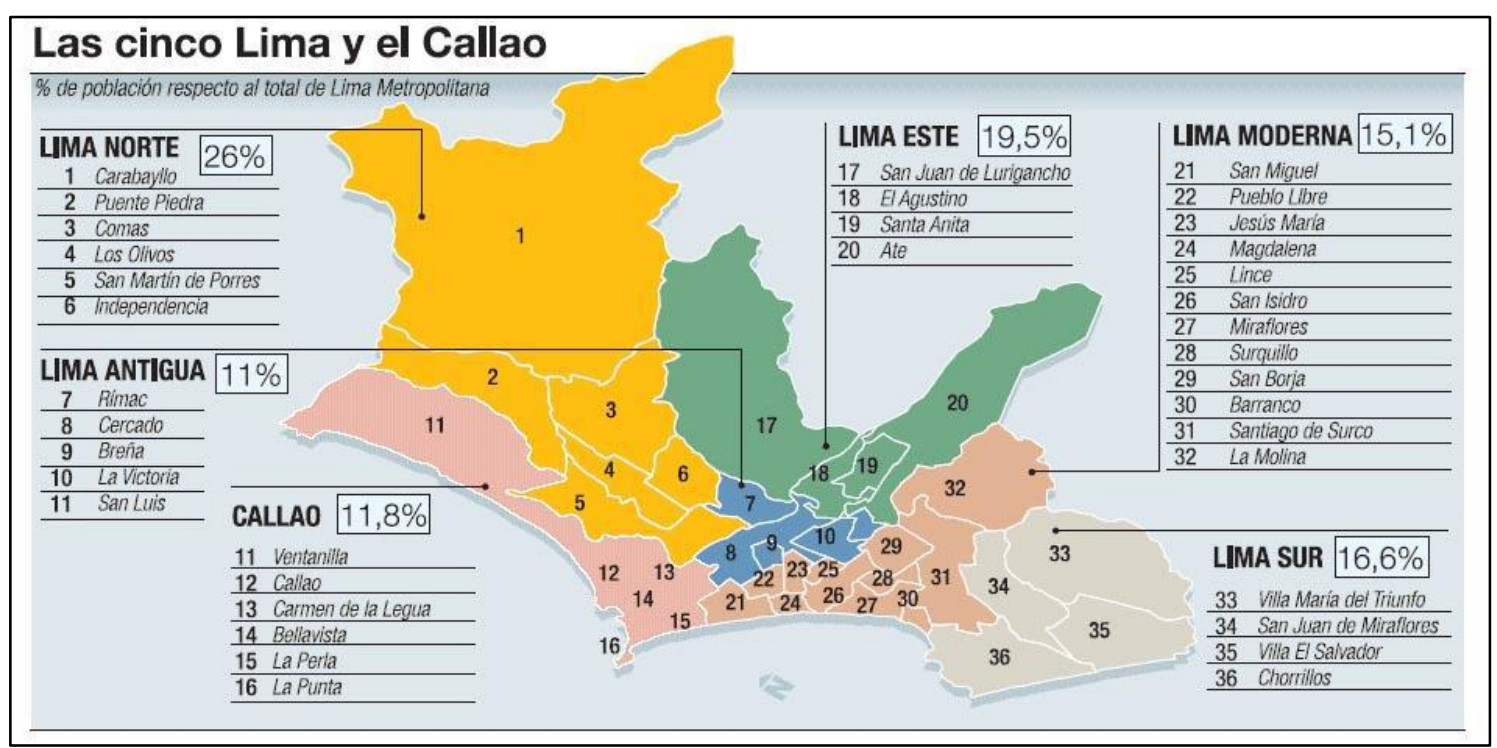

Fig. 13:Las cinco Limas

Fuente: IPSOS-Apoyo 2007

\section{Distritos:}

Carabayllo / Ancón / Puente Piedra / San Martin / Santa Rosa / Comas / Independencia / Los Olivos

\section{Ejes:}

El primer eje se extiende por el Noreste a lo largo de la cuenca del Río Chillón y el segundo por el Noroeste a lo largo de la Panamericana Norte.

\section{Vías conectoras:}

Conexión con el Centro Histórico, a través de la Av. Túpac Amaru y la Panamericana Norte.

Conexión con San Miguel, a través de la Av. Universitaria. 


\section{Ficha Técnica:}

- $\quad$ SUPERFICIE: $835,75 \mathrm{~km} 2$

- FUNDACION: 1930

- DISTRITOS: 8

- $\quad$ ALTITUD: 200-300 m.s.n.m

- N $^{\circ}$ HABITANTES: $2083583 \mathrm{hab}$.

- TEMPERATURA PROMEDIO:

$14^{\circ}$ en invierno y $22^{\circ}$ en verano

- HUMEDAD: $86 \%$ al año

\section{Límites:}

- NORTE: Provincia de Huaral

- SUR: Rímac y Cercado de Lima

- OESTE: Provincia del Callao y Océano Pacífico

- ESTE: San Juan de Lurigancho, Provincia de Huarochirí y Canta (Juan Luis Orrego Penagos, 2010)

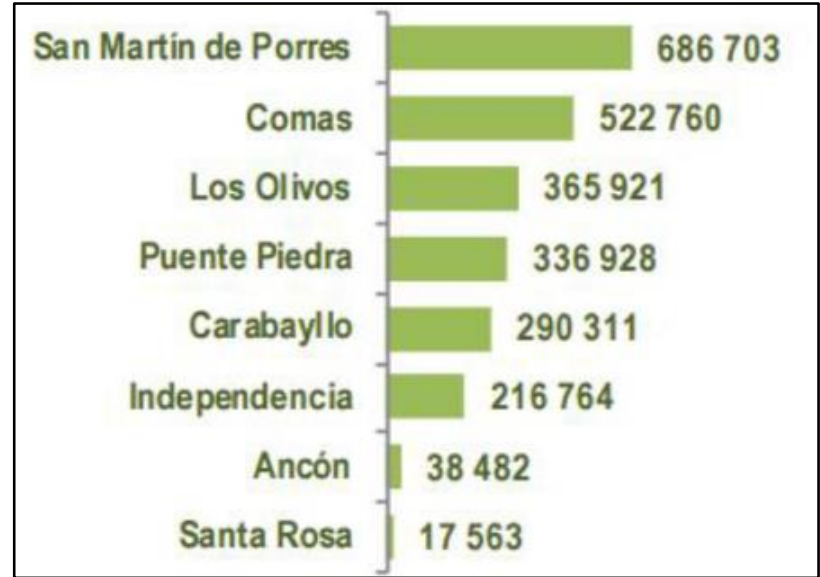

Fig. 14: Cantidad poblacional en distritos de Lima Norte

Fuente: Instituto Nacional de Estadística e Informática. 2014 


\subsection{Historia de Lima Norte}

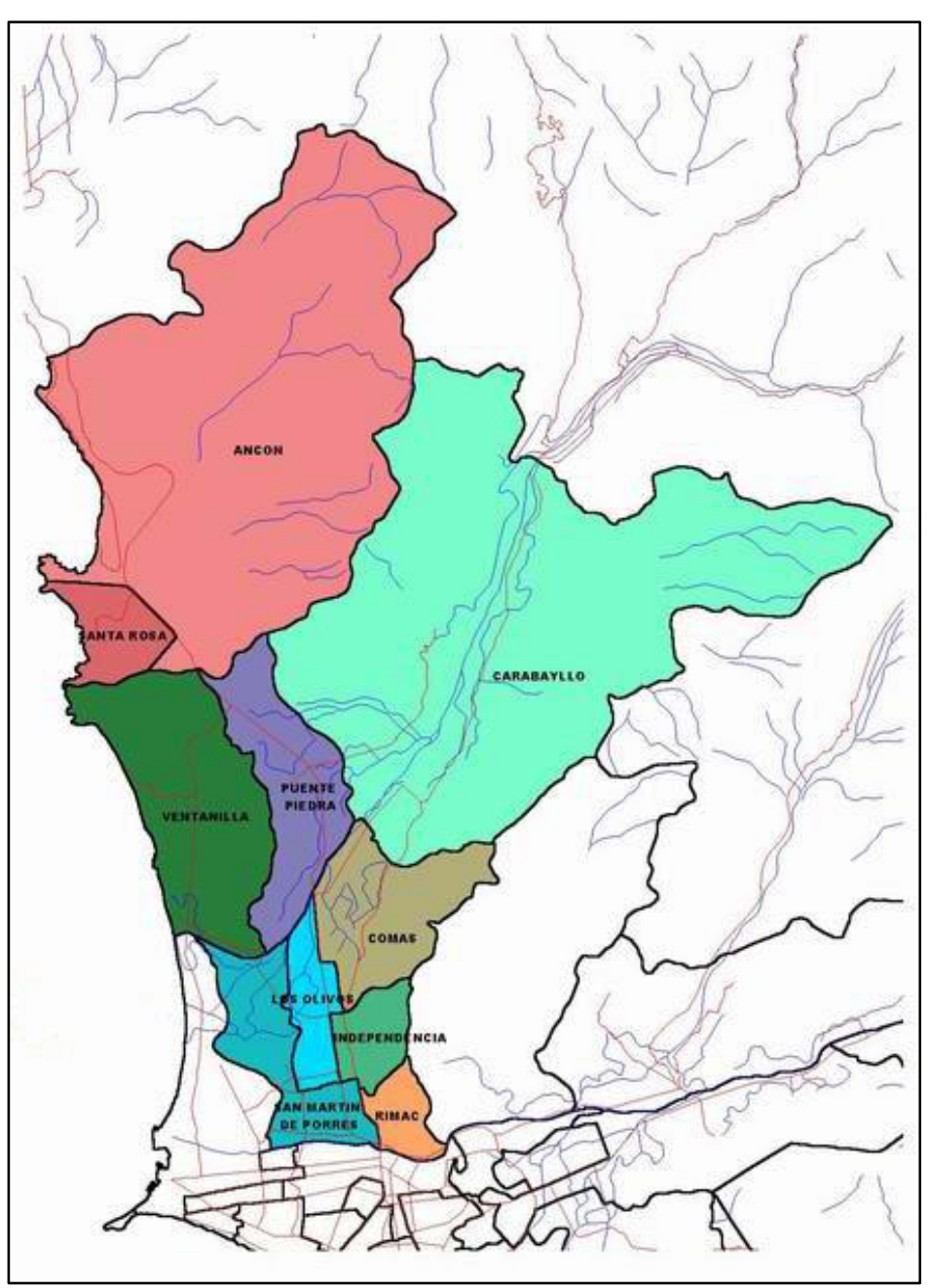

Fig. 15: Lima Norte, sus inicios

Fuente: Blog Pucp de Juan Luis Orrego Penagos, 2010

El termino Cono Norte, al igual que en otras metrópolis, fue acuñado inicialmente para distinguir los ejes de crecimiento urbano de Lima Metropolitana y los lugares donde se concentraban las poblaciones de pobreza y pobreza extrema de la capital. El termino Lima Norte es más reciente referido a esta misma zona geográfica nace en base a una redefinición del espacio urbano de la ciudad a partir de su desarrollo económico, urbano y factores de dependencia: La ciudad de Lima ya no tiene conos o extremos dependientes de un centro económico, sino está constituido por centros de desarrollo económico independientes, uno de ellos y el de mayor crecimiento es Lima Norte. En efecto, Lima Norte ha adquirido mayor notoriedad en la vida nacional por su crecimiento económico a partir del año 2000. Prueba de ello es que los distritos de Los Olivos y San Martín de Porres han elevado sus categorías de sectores socio-económicos C y D hacia B y C respectivamente. (Juan Luis Orrego Penagos, 2010)

Los orígenes de Lima Norte se remontan a la década de 1930 con la construcción de los barrios obreros en Caquetá y San Martín de Porres, construidos durante el gobierno del general Benavides. Hasta allí, hubo cierta "planificación” en esta zona de Lima. Pero en la década siguiente, surgen las invasiones y las barriadas. A mediados de la década de 1950 ya están constituidas las barriadas “27 de octubre”, "El Pedregal” y toda la zona de 
"Zarumilla". La Panamericana Norte sería, junto a la carretera a Canta y al ferrocarril Lima-Ancón, un eje decisivo para el crecimiento de Lima Norte. A partir de la década de 1960 se produciría una sucesión de nuevos asentamientos: "Pampa de cuevas", "La libertad", "Comas", "Carabayllo" e "Independencia", entre otros. (Juan Luis Orrego Penagos, 2010)

En la década de 1990, concluyó un ciclo histórico y se inició otro: la barriada aspira a convertirse en ciudad. Deja de ser el "Cono Norte" y surge la "Lima Norte de hoy. Temas como el de la renovación, el ornato público y la instalación de un equipamiento urbano adquieren sentido para los nuevos distritos. Se inicia así un proceso de renovación urbana de la nueva-vieja periferia constituida por cientos de barriadas, muchas de las cuales aparecen hoy como demasiado viajas sin haber llegado nunca a ser ciudades nuevas. (Juan Luis Orrego Penagos, 2010)

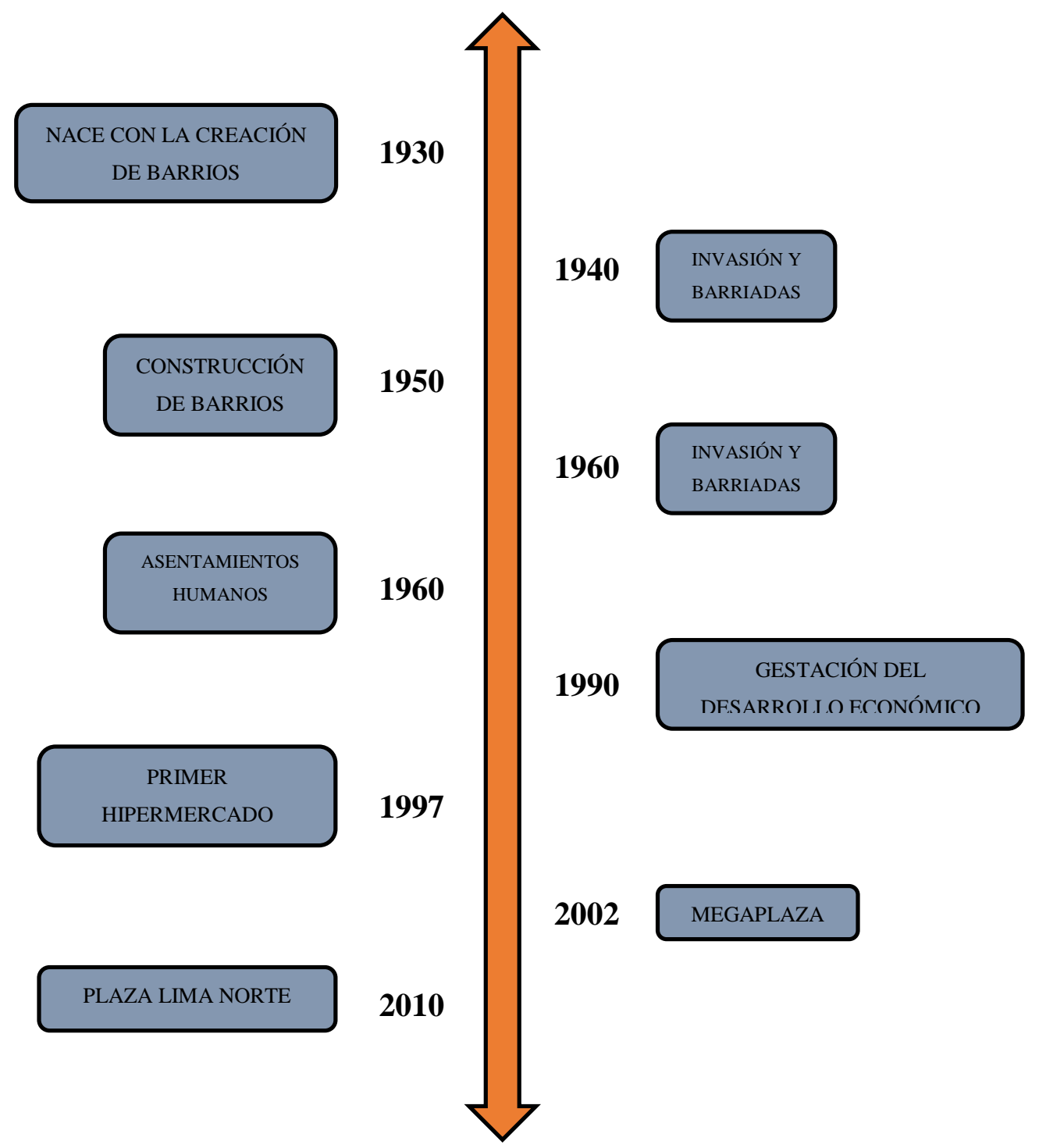

Fig. 16: Línea de tiempo Lima Norte/Elaboración propia 
5.5. Expediente urbano

5.6. Terreno escogido 


\section{CAPÍTULO VI - Usuario}

\subsection{Definición}

Las actividades que se desarrollan en esta escuela son variadas, ya que concentran actividades de enseñanza, exposición y difusión. Es necesario pensar en los espacios donde el usuario va a desenvolver. Por este motivo, se definen dos tipos de usuario pensando en los espacios que se utilizarán y las actividades que harán: usuario permanente y usuario temporal o eventual.

\subsection{Público objetivo}

El público dirigido de esta escuela de Artes Escénicas no solo es de San Martin de Porres, sino que, al conformar un núcleo en Lima Norte, el carácter de este equipamiento en la zona es interdistrital, pudiendo así, satisfacer parte de las necesidades culturales que se requiere en Lima Norte.

San Martin de Porres cuenta con una población de 686703 personas y ocupa el primer lugar respecto a la población en Lima Norte. El proyecto por estar ubicado cerca a la Panamericana Norte se conecta con los demás distritos de Lima Norte convirtiéndose en un equipamiento interdistrital.

Además, Lima Norte cuenta con un potencial artístico que se ha ido desarrollando en los últimos años evidenciando el interés artístico de los jóvenes. Este festival se desarrolla en las calles y en espacios públicos donde se observa la carencia actual de equipamientos artísticos en la zona. 


\subsubsection{Artistas}

Los artistas son todas aquellas personas que practican el teatro, la danza o la música, como también todas aquellas personas que deseen aprender y explorar sus talentos.

La escuela de Artes Expresivas cumple dos funciones: la formación y difusión artística, y este tipo de público se desarrollará principalmente en la etapa de formación. Luego de aplicar los conocimientos aprendidos, estos mismos puedan expresar y difundir aquellas ramas artísticas en las que se pueden desenvolver. Cabe resaltar que este tipo de público es el más importante, ya que los espacios principales espacios del proyecto se desarrollarán en torno a este y a las necesidades que requieren.

\subsubsection{Aficionados al arte}

Otro público objetivo son los aficionados al arte escénico y los participantes de taller de terapia de artes expresivas, es decir, aquellas personas que tienen un gran interés por presenciar y expresar las representaciones artísticas. Como ya se mencionó en el caso anterior, el proyecto a desarrollar alberga dos tipos de funciones: formación y difusión artística, y la rama al que pertenece este público objetivo es la parte de difusión artística. Este tipo de público es importante, ya que, son los espectadores los que hacen posible la comunicación entre el artista y su rama, son ellos a los que va dirigido este tipo de representaciones y son los principales protagonistas de los espacios de difusión. 


\subsection{Tipos de usuarios}

\subsubsection{Eventual}

Es aquel usuario transitorio, es decir, su permanencia en el lugar es por tiempo determinado y limitado, y las actividades que este realizará son objetivas.

\section{Tipos}

\section{Espectadores}

Espectador de danza / espectador de teatro / espectador de música

$\underline{\text { Apoderados o padres de familia }}$

\section{Razones por las que acudirán al proyecto}

\section{$\underline{\text { Espectadores }}$}

Como su mismo nombre lo dice, el público que se encentra expectante de las obras escénicas a realizar, los cuales tienen un fin cultural, diversión o distracción, o apoyo familiar.

\section{Apoderados o padres de familia:}

Los usuarios permanentes, específicamente, los alumnos, son en su mayoría jóvenes que se encuentran egresados del colegio. Esto quiere decir, que, en la mayoría de casos, son los padres de familia quienes están a cargo de este tipo de usuario y necesitan conocer el lugar ya sea para recibir informes y saber qué tipo de actividades se ofrecerá a su menor hijo o hija. 


\subsubsection{Permanente}

Es aquel usuario constante, es decir, su permanencia en el lugar es todo el tiempo en que este centro de artes se encuentra activo y las actividades que este realiza son variadas y extensas. Este tipo de usuario corresponde principalmente a los que trabajan y adquieren servicios. En los usuarios que trabajan: encontramos a los docentes de artes escénicas, el personal administrativo, el personal de limpieza, entre otros; y dentro de los usuarios que adquieren servicios se encuentran los alumnos de danza, música y teatro.

\section{Tipos}

Los que trabajan:

Docentes de Danza / Docentes de Música / Docentes de Teatro / Personal Administrativo y Directivo / Personal de Limpieza

$\underline{\text { Los que adquieren servicios }}$

Alumnos de danza / alumnos de música / alumnos de teatro

\section{Razones por las que acudirán al proyecto}

$\underline{\text { Los que trabajan }}$

Es el lugar de trabajo tanto como para el docente, como para el personal administrativo y de limpieza. Apoderados o padres de familia:

\section{$\underline{\text { Docentes }}$}

Personal contratado y permanente que abarca los temas de enseñanza y especialización de las ramas artísticas (danza, música y teatro). Se involucra instruyendo al alumno en los conocimientos teóricos y prácticos para desarrollar el talento del alumno y ayudar a perfeccionar su técnica.

\section{$\underline{\text { Personal Administrativo }}$}

Personal contratado y permanente que abarca la parte administrativa (aspectos económicos del Centro de Artes Escénicas) y directiva (aspectos funcionales y de ejecución en cuanto a las actividades a desarrollar). Se involucra en la organización y coordinación para que este funcione de forma eficiente. 


\section{$\underline{\text { Personal de Limpieza }}$}

Personal contratado que abarca las actividades referentes al mantenimiento de las instalaciones de una escuela de Artes Escénicas. Estas personas realizan un trabajo permanente para lograr el buen estado de la infraestructura y el beneficio de todos.

\section{$\underline{\text { Los que adquieren servicios }}$}

Es el lugar de estudio, donde los alumnos recibirán las enseñanzas en conjunto y personalizadas para el desarrollo de su talento y su perfección en la técnica.

\section{$\underline{\text { Alumnos de Música }}$}

Conjunto de personas que van con el objetivo de recibir enseñanza teórica y práctica de los ámbitos musicales y ser los principales protagonistas en las obras de representación.

\section{$\underline{\text { Alumnos de Danza }}$}

Conjunto de personas que van con el objetivo de recibir enseñanza teórica y práctica de los ámbitos de la danza y ser los principales protagonistas en las obras de representación.

\section{Alumnos de Teatro}

Conjunto de personas que van con el objetivo de recibir enseñanza teórica y práctica de los ámbitos teatrales y ser los principales protagonistas en las obras de representación.

\section{$\underline{\text { Alumnos de TAE }}$}

Conjunto de personas que van con el objetivo de exponer sus dotes artísticos, recibir terapia aplicada a cada caso en particular, explorar nuevas virtudes y potenciar su creatividad. 


\subsection{Usuario por paquetes funcionales}

Tabla 2: Tabla de usuario por paquete funcional

\begin{tabular}{|c|c|c|}
\hline FUNCIONES & TIPO DE USUARIO & CARACTERÍSTICAS DEL USUARIO \\
\hline HALL INGRESO & $\begin{array}{l}\text { Usuario eventual } \\
\text { Usuario permanente }\end{array}$ & $\begin{array}{l}\text { a. Usuario curioso (pregunta, observa y averigua) } \\
\text { b. Usuario estudiante (Ingresa a la escuela) } \\
\text { c. Usuario espectador (se dirige a los espacios de } \\
\text { representación) } \\
\text { d. Usuario trabajador (Informes. Seguridad, etc.) }\end{array}$ \\
\hline $\begin{array}{c}\text { ZONA } \\
\text { ADMINISTRATIVA }\end{array}$ & Usuario permanente & $\begin{array}{l}\text { a. Usuario trabajador (personal administrativo) } \\
\text { b. Usuario estudiante (solicita gestión de trámites, reclamos, } \\
\text { etc.) } \\
\text { c. Usuario de servicio (personal de limpieza) }\end{array}$ \\
\hline $\begin{array}{l}\text { ZONA DE } \\
\text { FORMACIÓN } \\
\text { ACADEMICA }\end{array}$ & Tipo de usuario & $\begin{array}{l}\text { a. Usuario trabajador (personal docente) } \\
\text { b. Usuario estudiante (aprende las enseñanzas teóricas y } \\
\text { prácticas) } \\
\text { c. Usuario de servicio (personal de limpieza) }\end{array}$ \\
\hline $\begin{array}{l}\text { ZONA DE DIFUSIÓN } \\
\text { CULTURAL }\end{array}$ & Tipo de usuario & $\begin{array}{l}\text { a. Usuario trabajador (personal docente que organiza } \\
\text { eventos y espectáculos) } \\
\text { b. Usuario estudiante (expone y aplica lo aprendido en } \\
\text { clase) } \\
\text { c. Usuario de servicio (personal de limpieza) } \\
\text { d. Usuario espectador (observa el espectáculo) }\end{array}$ \\
\hline ZONA DE SERVICIOS & Usuario permanente & $\begin{array}{l}\text { a. Usuario estudiante (zonas de descanso y/o sociales) } \\
\text { b. Usuario trabajador (bibliotecarios, cocineros, } \\
\text { organizadores, entre otros) } \\
\text { c. Usuario de servicio (personal de limpieza) }\end{array}$ \\
\hline
\end{tabular}




\subsection{Usuario del área de formación y difusión cultural}

\section{Formación académica}

Tabla 3: Tabla del usuario de danza

\begin{tabular}{|c|c|c|}
\hline \multicolumn{3}{|c|}{ Usuario Danza } \\
\hline & ¿Quiénes son? & ¿Cómo son? - Características \\
\hline \multirow{3}{*}{ @ } & Principiantes & $\begin{array}{l}\text { En este grupo entran los bailarines de formación temprana, } \\
\text { quienes son niños y adolescentes entre } 8 \text { y } 14 \text { años, quienes } \\
\text { reciben una temprana preparación para formarse como } \\
\text { bailarines profesionales. }\end{array}$ \\
\hline & Nivel Intermedio & $\begin{array}{l}\text { Jóvenes entre } 12 \text { y } 17 \text { años, quienes ya concluyeron con la } \\
\text { formación temprana }\end{array}$ \\
\hline & Experimentados & $\begin{array}{l}\text { Jóvenes entre } 17 \text { y } 25 \text { años que poseen una buena condición } \\
\text { física y mental. Deben tener conocimientos teóricos además de } \\
\text { la práctica, conocimientos anatómicos sobre diversas teorías, } \\
\text { etc. }\end{array}$ \\
\hline \multicolumn{2}{|r|}{ ¿Quiénes son? } & ¿Cómo son? - Características \\
\hline 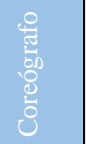 & \multicolumn{2}{|c|}{$\begin{array}{l}\text { Artista compositor de danza. Para poder ser coreógrafo debe haber pasado por una formación superior como o bailarín. } \\
\text { Se encarga de la recreación de la obra, o remontan alguna existente, que podrá ser inspirada en una obra literaria, musical } \\
\text { o pictórica. Planea las fases, los matices y movimientos expresivos. }\end{array}$} \\
\hline 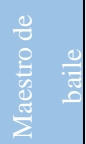 & \multicolumn{2}{|c|}{$\begin{array}{l}\text { Es el encargado de la enseñanza y la realización de las obras de danza con el cuerpo de baile. Imparte técnicas conocidas } \\
\text { por la danza. Tiene como funciones principales: la organización del trabajo, el problema pedagógico y la interpretación } \\
\text { artística. }\end{array}$} \\
\hline
\end{tabular}

Tabla 4: Tabla del usuario de teatro

\begin{tabular}{|c|c|c|}
\hline \multicolumn{3}{|c|}{ Usuario Teatro } \\
\hline \multicolumn{2}{|r|}{ ¿Quiénes son? } & ¿Cómo son? - Características \\
\hline$\frac{0}{\frac{\partial}{3}}$ & Formación Preparatoria & $\begin{array}{l}\text { Alumnos de la academia preparatoria de la Escuela Nacional } \\
\text { Superior de Arte Dramático. Lo mismo ocurre con la academia } \\
\text { preparatoria de la Pontifica Universidad Católica para las } \\
\text { especialidades de teatro o Facultad de Artes Escénicas. Jóvenes } \\
\text { con } 16 \text { años como mínimo o que cursen el último año de } \\
\text { formación académica. }\end{array}$ \\
\hline & Formación Superior & $\begin{array}{l}\text { Alumnos de } 16 \text { años como edad mínima y con formación } \\
\text { secundaria completa. }\end{array}$ \\
\hline$\frac{5}{2}$ & \multicolumn{2}{|c|}{$\begin{array}{l}\text { Según el reglamento del ENSAD y la norma del Ministerio de Educación, el profesor debe haber recibido formación } \\
\text { universitaria o superior y en algunos casos requiere haber realizado alguna especialización para poder impartir su } \\
\text { conocimiento. }\end{array}$} \\
\hline
\end{tabular}


Tabla 5: Tabla del usuario de Música

\begin{tabular}{|c|c|c|c|}
\hline \multicolumn{4}{|c|}{ Usuario Música } \\
\hline \multicolumn{3}{|c|}{ ¿Quiénes son? } & ¿Cómo son? - Características \\
\hline \multirow{3}{*}{$\frac{3}{4}$} & \multirow{3}{*}{ 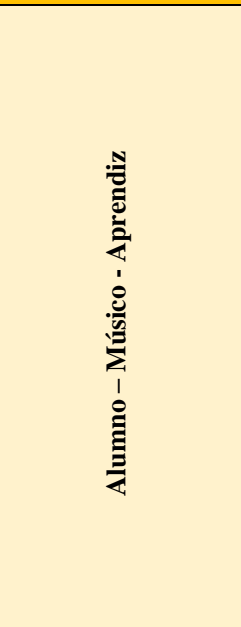 } & Nivel Inicial & $\begin{array}{l}\text { Niños entre los } 8 \text { y } 14 \text { años, quienes pasan por un proceso de } \\
\text { formación de } 6 \text { años. Estos niños a la par deben recibir una } \\
\text { formación escolar, como requisito para poder ser parte del } \\
\text { conservatorio. }\end{array}$ \\
\hline & & Nivel Intermedio & $\begin{array}{l}\text { Adolescentes y jóvenes entre } 14 \text { y } 16 \text { años. Este periodo tiene } \\
\text { una duración de } 2 \text { años. También es requisito la formación } \\
\text { escolar. }\end{array}$ \\
\hline & & Nivel superior & $\begin{array}{l}\text { Se reciben adolescentes a partir de los } 16 \text { años, y el único } \\
\text { requisito es haber concluido la secundaria completa y a } \\
\text { diferencia del conservatorio, no existe edad mínima. Jóvenes de } \\
15 \text { a } 25 \text { años, que reciben una formación superior en diversas } \\
\text { especialidades musicales. Deben estar cursando o haber } \\
\text { concluido su formación secundaria. }\end{array}$ \\
\hline ; & Músico - Mentor & \multicolumn{2}{|c|}{$\begin{array}{l}\text { Luego de clases es importante que cuente con un lugar para descansar e intercambiar ideas de } \\
\text { forma diaria con otros profesores. }\end{array}$} \\
\hline ent & Músico - Interprete & \multicolumn{2}{|c|}{ Músicos invitados, que imparten sus conocimientos. } \\
\hline
\end{tabular}

\section{Tabla 6: Tabla del usuario de TAE (Terapia de artes expresivas)}

\begin{tabular}{|c|c|c|}
\hline \multicolumn{3}{|c|}{ Usuario TAE (Terapia de artes expresivas) } \\
\hline & ¿Quiénes son? & ¿Cómo son? - Características \\
\hline \multirow[t]{2}{*}{$\frac{\Xi}{\gtrless}$} & Talleres terapéuticos & $\begin{array}{l}\text { Alumnos (niños/jóvenes/adultos) separados por turnos en aulas } \\
\text { individuales, grupales de } 4 \text { hasta de } 8 \text { personas para que } \\
\text { estimulen su creatividad } \\
\text { Personas con problemas leves de personalidad, discapacidad } \\
\text { sensorial. }\end{array}$ \\
\hline & Formación Superior & $\begin{array}{l}\text { Profesionales técnicos o universitarios que deseen recibir } \\
\text { diplomado de artes expresivas y formación de artes expresivas. }\end{array}$ \\
\hline$\frac{\grave{b}}{3}$ & \multicolumn{2}{|c|}{$\begin{array}{l}\text { Profesores con estudios en terapia de artes expresivas / Psicólogos. } \\
\text { Profesores invitados para clases al aire libre en el boulevard promocionando sus clases. }\end{array}$} \\
\hline
\end{tabular}

Tabla 7:Tabla de usuario de talleres libres

Usuario de talleres libres

Son aquellos alumnos que acuden a cursos libres de manera opcional, y que no reciben una formación superior. 
Tabla 8: Tabla de usuario invitado o eventual

Invitados / Usuarios eventuales

Son familiares o amigos que vienen a presenciar actuaciones pequeñas o internas, que se realizan entre los alumnos.

Tabla 9: Tabla de usuario de la zona administrativa

Usuarios de la zona Administrativa

Aquí se encuentran los encargados del área de logística, contabilidad, recursos humanos, etc.

Tabla 10: Tabla de usuario de la dirección académica

Usuarios de la dirección Académica

Aquí encontramos dl director general de la institución, además de los decanos de cada carrera 


\section{Difusión cultural}

Tabla 11: Tabla del público o usuario eventual

Tabla 12: Tabla del personal administrativo

\begin{tabular}{|c|l|}
\hline \multicolumn{2}{|c|}{ Personal Administrativo } \\
\hline Director General del Teatro & $\begin{array}{l}\text { Dirige el funcionamiento general del Teatro. Supervisa el correcto trabajo del gerente } \\
\text { administrativo, recursos humanos y demás. }\end{array}$ \\
\hline Gerente Administrativo & $\begin{array}{l}\text { Distribuye los recursos económicos y humanos. Verifica el eficaz funcionamiento de las } \\
\text { representaciones y ensayos. Alquila el teatro a algún grupo artístico. Verifica el trabajo del } \\
\text { personal de taquilla, porteros, guardarropas y acomodadores. }\end{array}$ \\
\hline Encargado de Contabilidad & $\begin{array}{l}\text { Maneja cuestiones fiscales de ingresos y egresos del teatro. Trabaja con el tesorero y dos } \\
\text { empleados para correspondencia y archivos. Trabaja con el personal de taquilla y ellos rinden } \\
\text { cuentas al final de la función. }\end{array}$ \\
\hline Encargado de Recursos & $\begin{array}{l}\text { Resuelve a que grupos o entidades facilitara entradas con descuentos. Trata con las autoridades } \\
\text { permisos y seguros para los trabajadores. }\end{array}$ \\
\hline
\end{tabular}

Tabla 13: Tabla del área de dirección y producción

\begin{tabular}{|c|c|}
\hline \multicolumn{2}{|c|}{ Área de Dirección y Producción } \\
\hline Director Artístico & Organiza y trata las necesidades de los artistas. \\
\hline Productor & Realiza aportes económicos para materializar la obra. Controla los aspectos de producción de \\
& la obra. \\
\hline
\end{tabular}

Tabla 14: Tabla del área de marketing y publicidad

\begin{tabular}{|c|c|}
\hline \multicolumn{2}{|r|}{ Área de Marketing y Publicidad } \\
\hline Director de Publicidad & $\begin{array}{l}\text { Organiza y lleva a cabo campaña de propaganda y publicidad mediante anuncios directos en } \\
\text { prenda, radio y televisión. }\end{array}$ \\
\hline $\begin{array}{l}\text { Encargado de Relaciones } \\
\text { Públicas }\end{array}$ & $\begin{array}{l}\text { Fomenta la relación de actores e instituciones a través de los medio de comunicación ya sea } \\
\text { nacional o internacional. }\end{array}$ \\
\hline
\end{tabular}


Tabla 15: Tabla del personal de soporte técnico

\begin{tabular}{|c|c|}
\hline \multicolumn{2}{|c|}{ Personal de Soporte Técnico } \\
\hline Técnico de Luces & Controla y dirige los efectos de iluminación de la sala. \\
\hline Técnico de sonido & Controla y dirige los efectos de sonido de la sala. \\
\hline Escenógrafo & Realiza plantas y cortes del diseño de la escenografía. Se encarga de supervisar la \\
\hline miseño de Vestuario & Realiza el diseño y supervisa el proceso de elaboración del vestuario. \\
\hline Encargado de maquillaje y & Se encarga de realizar a los artistas. \\
\hline peinado & \\
\hline
\end{tabular}

Tabla 16: Tabla del personal apoyo en la obra

\begin{tabular}{|c|c|}
\hline \multicolumn{2}{|r|}{ Personal de Apoyo en la Obra } \\
\hline Directo de escena & $\begin{array}{l}\text { Establece los caracteres de los personajes. Realiza ejercicios de memorización y ensayos de } \\
\text { movimiento. Coordina los actos, la música, la danza y los efectos visuales y de sonido. }\end{array}$ \\
\hline Apuntador & Verifica que los actores entren a tiempo en el dialogo en la escena. \\
\hline Traspunte & Avisa a los actores el momento en que deben ingresar a la obra. \\
\hline
\end{tabular}

\section{Tabla 17: Tabla del personal artístico}

\begin{tabular}{|c|c|}
\hline \multicolumn{2}{|c|}{ Personal Artístico } \\
\hline Actores & Aquí podemos encontrar a las primeras figuras, segundas figuras y extras. \\
\hline Bailarines & Al igual con los bailarines, pueden ser: primeros bailarines. Segundos bailarines y extras. \\
\hline Músicos & Se encargan del marco musical de la obra. \\
\hline
\end{tabular}


6.6. Recorridos de los usuarios

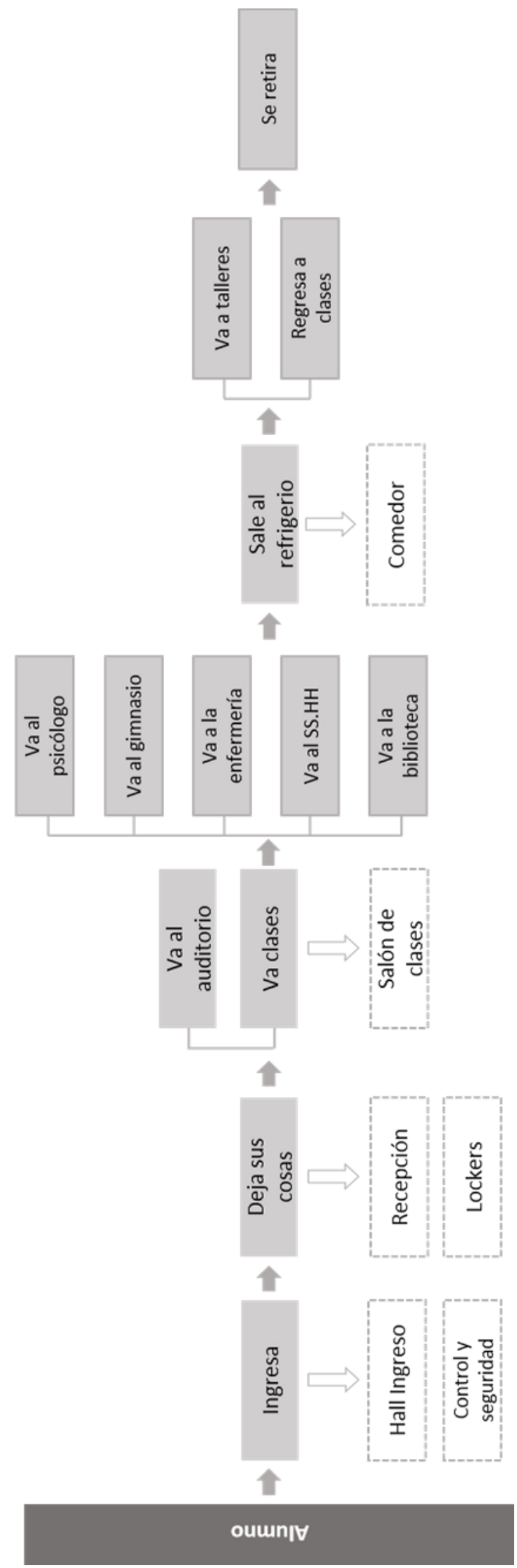

Fig. 17: Esquema del recorrido de alumno/Elaboración propia 


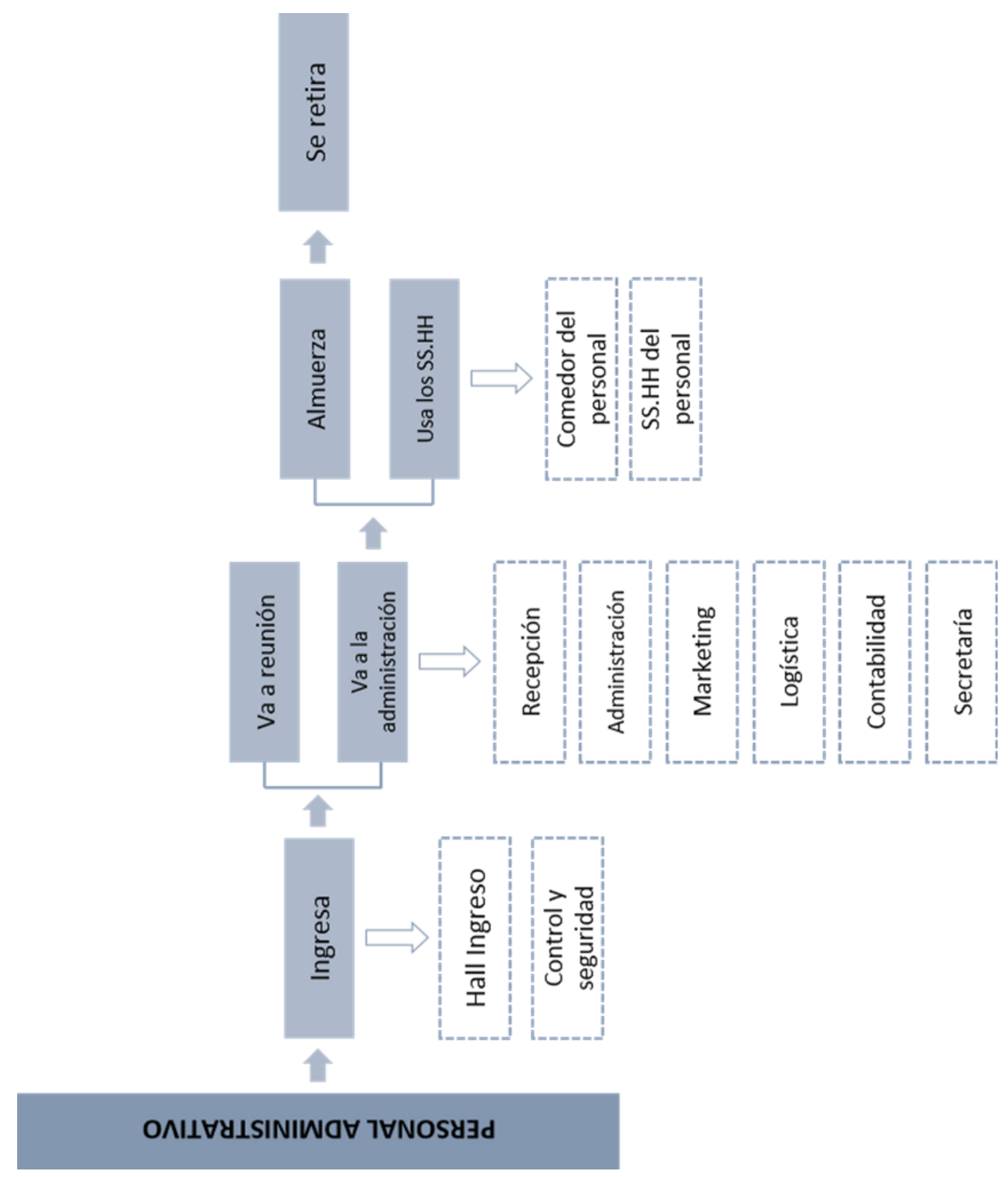

Fig. 18: Esquema del recorrido del personal administrativo/Elaboración propia 

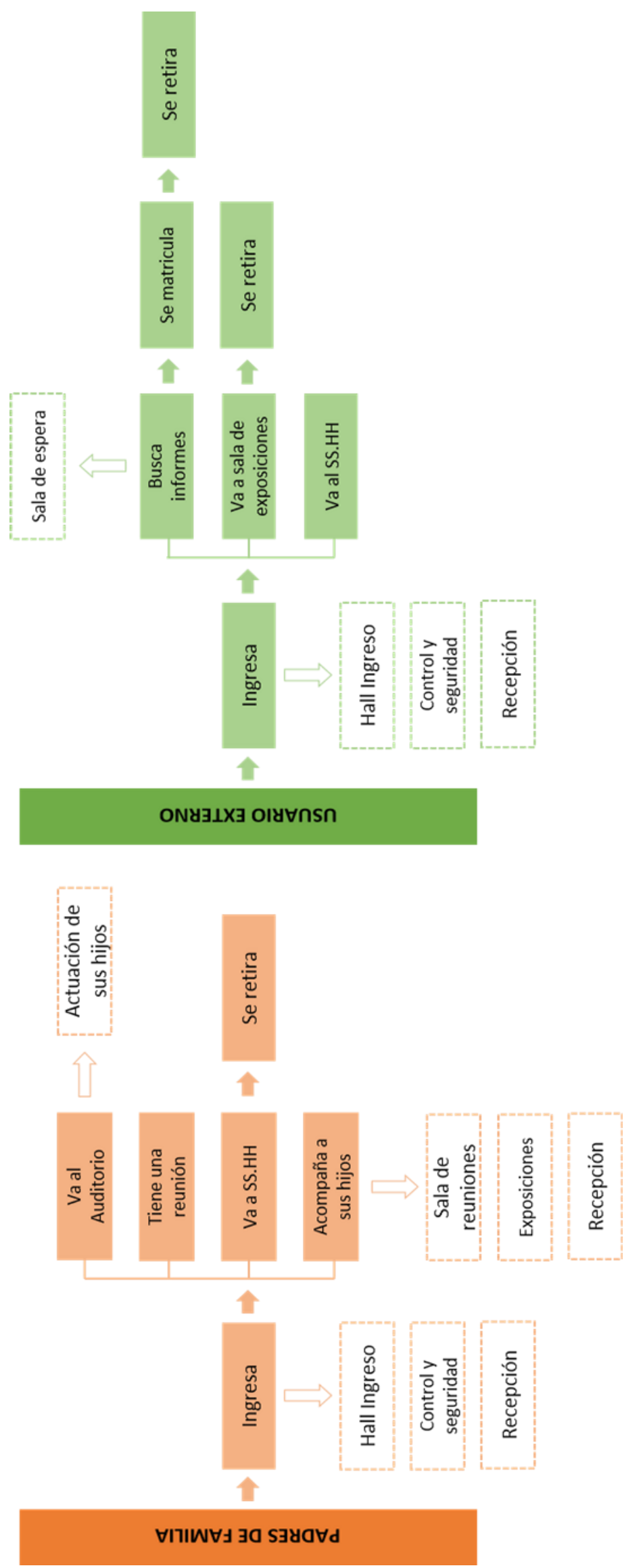

Fig. 19: Esquema del recorrido del usuario externo y padre de familia/Elaboración propia 


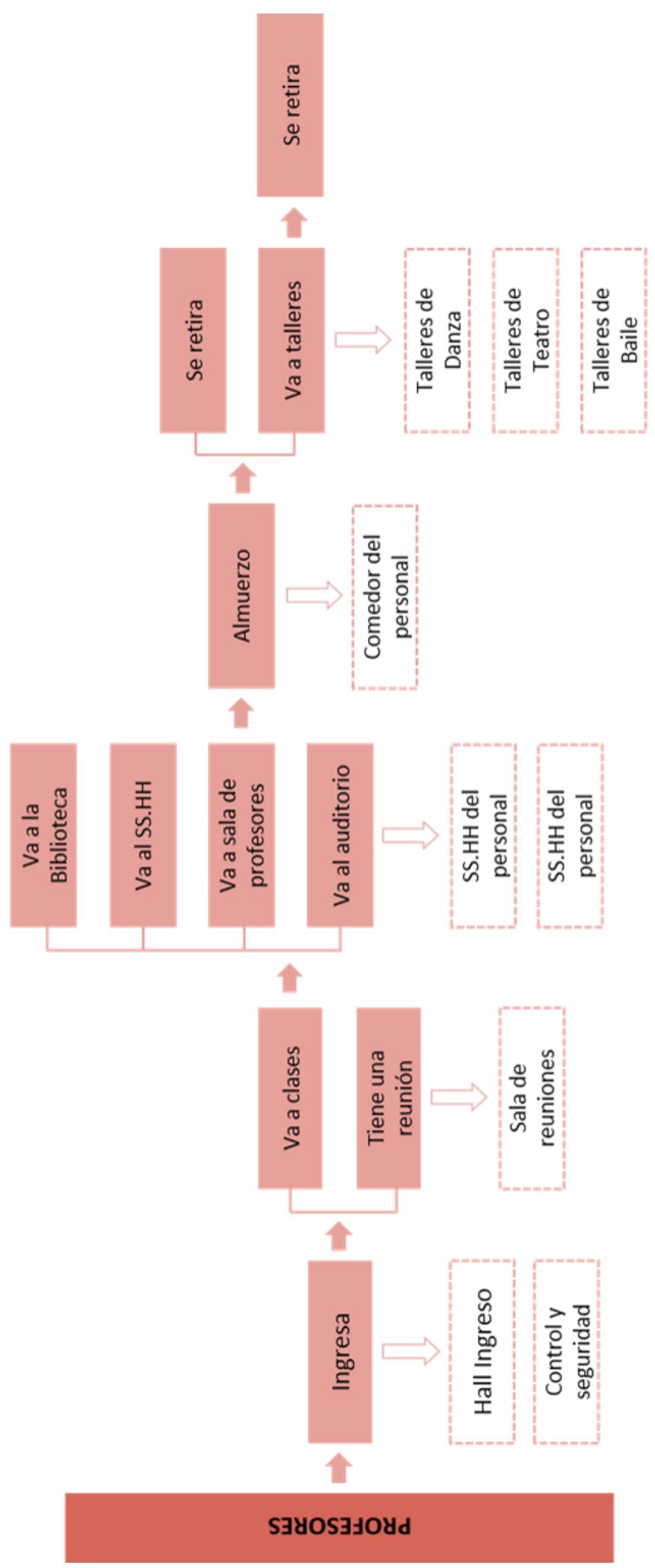

Fig. 20: Esquema del recorrido de los profesores 


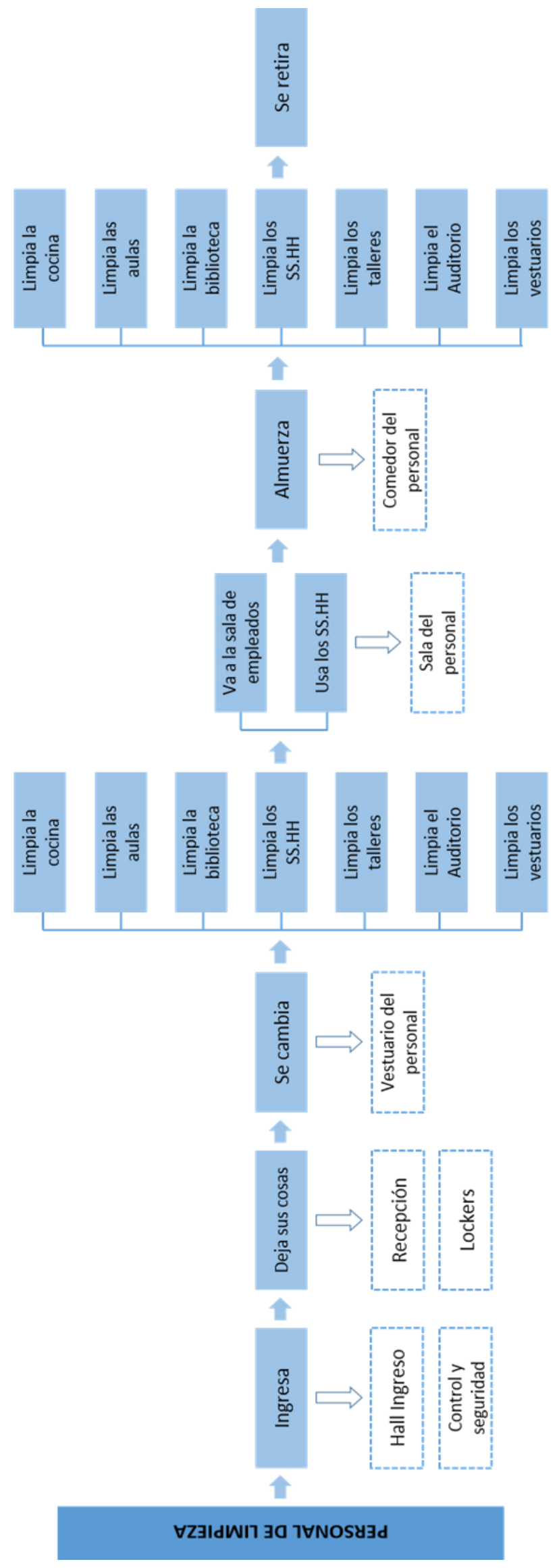

Fig. 21: Esquema del recorrido del personal de limpieza 


\subsection{Horario de usuarios}

Tabla 18: Horario de usuarios

\begin{tabular}{|c|c|c|c|c|c|c|}
\hline Usuario & 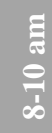 & 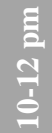 & $\begin{array}{l}\Xi \\
\Xi \\
\text { ב̃ }\end{array}$ & $\begin{array}{l}\text { 音 } \\
\text { 号 }\end{array}$ & 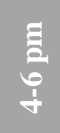 & \\
\hline \multicolumn{7}{|l|}{ Alumno } \\
\hline \multicolumn{7}{|l|}{ Profesores } \\
\hline \multicolumn{7}{|l|}{ Personal Administrativo } \\
\hline Personal de limpieza & & & & & & \\
\hline
\end{tabular}

Tabla 19: Horario de usuarios

\begin{tabular}{|c|c|}
\hline \multicolumn{1}{|c|}{} & HORARIOS \\
\hline ALUMNOS & Lunes a Viernes $(8: 30 \mathrm{am}-8: 00 \mathrm{pm})$ y Sábados $(8: 30 \mathrm{am}-5: 00 \mathrm{pm})$ \\
\hline DOCENTE & Lunes a Viernes $(8: 30 \mathrm{am}-8: 00 \mathrm{pm})$ y Sábados $(8: 30-5: 00 \mathrm{pm})$ \\
\hline PERSONAL & Lunes a Viernes $(8: 00 \mathrm{am}-1: 00 \mathrm{pm}$ y de 2:00 pm a 6:00 pm) \\
\hline ADMINISTRATIVO & Lunes a Sábado (7am $-12: 00 \mathrm{pm}$ y $1: 00 \mathrm{pm}-6: 00 \mathrm{pm})$ \\
\hline PERSONAL DE SERVICIO & \\
\hline
\end{tabular}




\subsection{Cantidad de usuarios}

Se hizo el cálculo de la demanda existente en el distrito de San Martin de Porres. Para esto se tomaron datos específicos acerca de la población del distrito en lapsos de tiempo (2010-2015), como también se utilizaron estadísticas sobre las carreras con mayor demanda en el mercado laboral y con exceso laboral y el número de personas vinculadas a las artes por categoría de ocupación.

\section{Población futura del 2015 al 2020}

Para hallar la población futura al 2020 en San Martin de Porres, se utilizó una fórmula matemática.

$$
\begin{gathered}
\text { TASA DE CRECIMIENTO = } \\
\text { PRESENTE - PASADO / PASADO }
\end{gathered}
$$

Tabla 20: Tabla de crecimiento poblacional en SMP (2010-2015)/Elaboración propia

\begin{tabular}{|c|c|c|}
\hline RANGO DE EDAD & 2010 & 2015 \\
\hline $15-19$ años & 60896 personas & 61443 personas \\
\hline $20-24$ años & 55894 personas & 65591 personas \\
\hline $25-29$ años & 55757 personas & 57738 personas \\
\hline TOTAL & 172547 personas & 184772 personas \\
\hline
\end{tabular}

Tasa de crecimiento de San Martin de Porres en los últimos 5 años:

Tasa de crecimiento $=184772-172547 / 172547$

Tasa de crecimiento $=\underline{\mathbf{0 . 0 7 1}}$

Población futura (año 2020) de San Martin de Porres en los últimos 5 años:

Población futura $=184772(1+0.071)^{2}$

Población futura $=\underline{\mathbf{2 6 0} 365}$ habitantes

\begin{tabular}{|c|c|c|c|}
\hline RUBRO & FUENTE & PORCENTAUE & POBLACIÓN \\
\hline Cantidad total de personas en San Martín de Porres & INEI & $100 \%$ & 700177 de habitantes \\
\hline Población actual de SMP (15-29 años) & INEI & $26 \%$ & 184772 de habitantes \\
\hline RUBRO & FUENTE & & FUENTE \\
\hline Población a futuro (2020) de SMP (15-29 años) & INEI & \multicolumn{2}{|c|}{260365 habitantes } \\
\hline Demanda en el mercado laboral (carreras de arte) $1.2 \%$ de la población total & INEI & \multicolumn{2}{|c|}{3124.38 habitantes } \\
\hline Núm. de personas vinculadas a las artes que se van a estar en el proyecto ( $17 \%$ de la población total) & INEI & \multicolumn{2}{|c|}{531 personas } \\
\hline
\end{tabular}

*Según el INEI el 17\% del total de las personas en el Perú se dedica al arte. 


\subsection{Normativa}

\section{RNE (REGLAMENTO NACIONAL DE EDIFICACIONES)}

\section{Artículo 9 - Normal A.4 - Capitulo II}

Calculo según el número de asientos / personas

- Auditorios: $1.00 \mathrm{~m} 2 /$ persona

- Salas de Clase: $1.50 \mathrm{~m} 2$ / persona

- Gimnasios y Camerinos: $4.00 \mathrm{~m} 2$ / persona

- Talleres, Laboratorios, Bibliotecas: $5.00 \mathrm{~m} 2$ / persona

- Uso Administrativo: $10.00 \mathrm{~m} 2$ / persona

\section{$\underline{\text { Articulo } 21 \text { y } 22 \text { - Norma A100 -Capitulo II }}$}

- Salas de Concierto, teatros, auditorios: deberán contar con pasaje transversal cada 20 filas.

\section{NEUFERT}

\section{Escuelas}

- Aulas típicas: $0.80-2 \mathrm{~m} 2$ / alumno

- Aulas grandes: 3-5 m2 / alumno

- Biblioteca / mediateca: 0.35 - $0.55 \mathrm{~m} 2$ / alumno $5 \mathrm{~m} 2$ / puesto de trabajo 20 -40 m2 (estantes - circulación) 100 libros

- Superficie total por alumno a tiempo completo: $25 \mathrm{~m} 2$

- La zona de enseñanza ocupa por lo general 10 -20\% de la superficie.

- Aulas de 50 -60 m2, aulas grandes de $85 \mathrm{~m} 2$, aula para conferencias 100 $-200 \mathrm{~m} 2$

- Almacén / mantenimiento: 15 m2 por edificio de aulas

- Equipamiento de aulas: mesas dobles de $1.2 \mathrm{~m} \times 0.60 \mathrm{~m}$ 


\section{CAPÍTULO VII - Programa arquitectónico}

\subsection{Paquetes funcionales}

Tabla 21: Tabla de paquete funcional, zona administrativa / Elaboración propia

\begin{tabular}{|l|c|}
\hline & Oficinas \\
ÁREA ADMINISTRATIVA & Atención al alumno \\
& Área de espera y atención \\
& SSHH Oficinas \\
& Comedor \\
& Sala de reuniones \\
\hline
\end{tabular}

Tabla 22: Tabla de paquete funcional, zona de servicio / Elaboración propia

\begin{tabular}{|c|c|c|}
\hline & Zona para el personal de servicio & $\begin{array}{c}\text { SSHH+Vestidores } \\
\text { Comedor }\end{array}$ \\
\cline { 2 - 3 } & ÁREA DE SERVICIO & Ingreso y área de control de servicio \\
Cuarto de basura \\
Cuarto de bombas \\
\end{tabular}

Tabla 23: Tabla de paquete funcional, zona de dirección y docencia / Elaboración propia

\begin{tabular}{|c|c|c|}
\hline \multirow{2}{*}{\begin{tabular}{|c|} 
ÁREA DE DIRECCIÓN Y \\
DOCENCIA
\end{tabular}} & $\begin{array}{c}\text { Hall-Control profesores y espera } \\
\text { Sala de profesores } \\
\text { Sala de reuniones }\end{array}$ \\
\cline { 2 - 3 } & Área de oficina & $\begin{array}{c}\text { Dirección y docencia } \\
\text { Directores y decanos }\end{array}$ \\
\cline { 2 - 3 } & Servicios & $\begin{array}{c}\text { Depósito } \\
\text { Comedor }\end{array}$ \\
& $\begin{array}{c}\text { SSHH/Vestidores docentes } \\
\text { SSHH/Vestidores (directores) }\end{array}$ \\
\hline
\end{tabular}


Tabla 24: Tabla de paquete funcional, zona de servicios complementarios / Elaboración propia

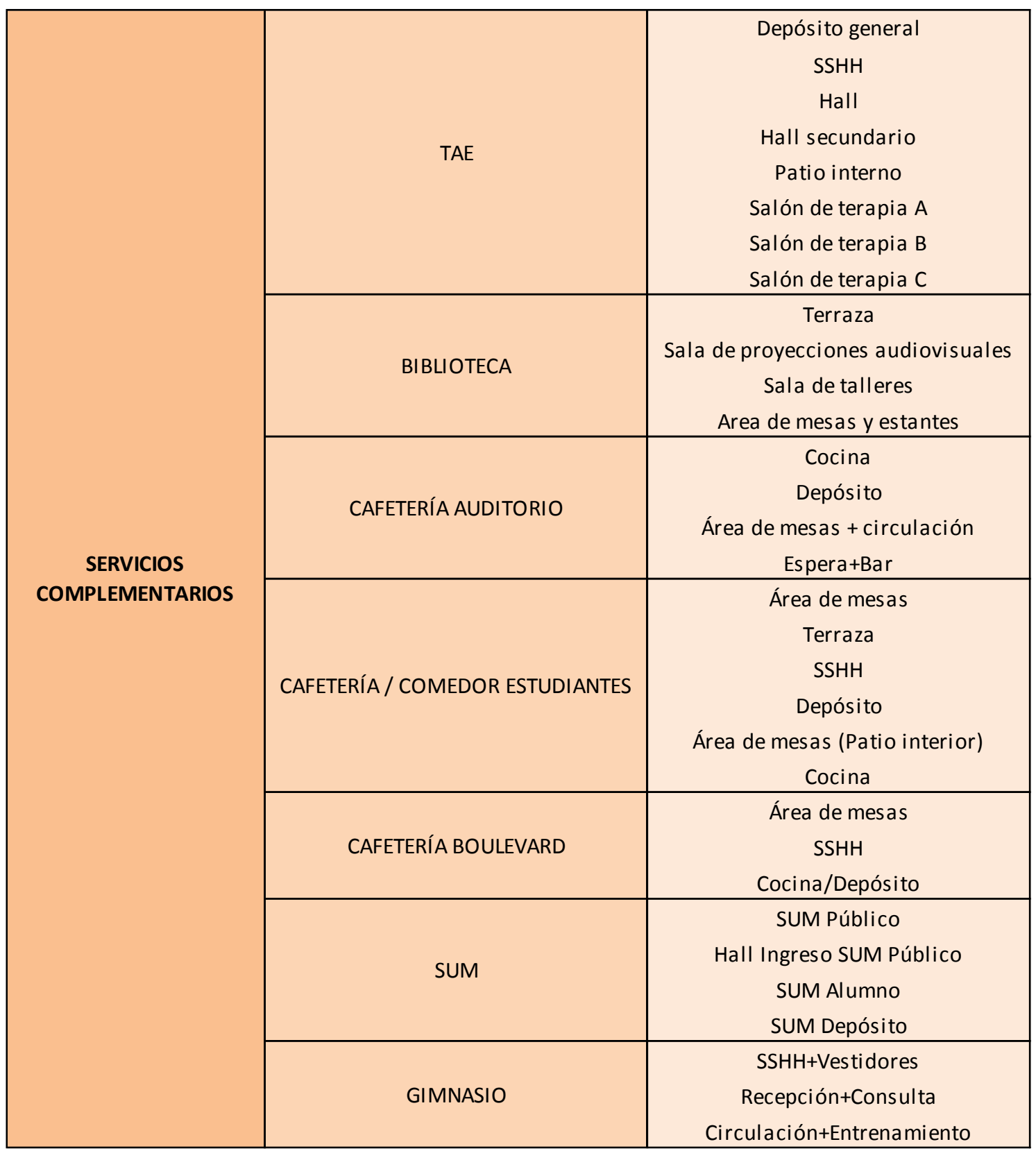

Tabla 25: Tabla de paquete funcional, zona académica / Elaboración propia 


\begin{tabular}{|c|c|c|}
\hline \multirow{7}{*}{ ÁREA ACADÉMICA } & Aulas teóricas & Aulas teóricas \\
\hline & Aulas prácticas & $\begin{array}{c}\text { Aula práctica coral } \\
\text { Aula de orquesta } \\
\text { Aula de ensambles } \\
\text { Sala de grabación } \\
\text { Aula de danza y acrobacia } \\
\text { Aula de interpretación } \\
\text { Aula enseñanza personalizada } \\
\text { Aula de percusión }\end{array}$ \\
\hline & Talleres & $\begin{array}{c}\text { Taller de vestuario } \\
\text { Taller de luces e iluminación } \\
\text { Taller de maquillaje } \\
\text { Salón de estudio + terraza } \\
\text { Sala de talleres electivos+dep }\end{array}$ \\
\hline & Espacios recreativos ext. techados & Patio central \\
\hline & Servicios higiénicos & SSHH + Vestidores \\
\hline & Depósitos & Depósito general de instrumentos \\
\hline & Tópico & $\begin{array}{c}\text { Depósitos } \\
\text { Recepción+consultorio }\end{array}$ \\
\hline
\end{tabular}

Tabla 26: Tabla de paquete funcional, zona de difusión / Elaboración propia

\begin{tabular}{|c|c|c|}
\hline & Talleres & $\begin{array}{c}\text { Taller de escenografías } \\
\text { Taller de maquillaje } \\
\text { Taller de vestuario }\end{array}$ \\
\hline ÁREA DE DIFUSIÓN & . & $\begin{array}{c}\text { Depósito Backstage } \\
\text { Vestidores camerinos } \\
\text { SSHH Backstage } \\
\text { Backstage } \\
\text { Escenario } \\
\text { Camerinos individuales } \\
\text { Camerino grupal tipo A } \\
\text { Camerino grupal tipo B } \\
\text { SSHH Público } \\
\text { Sala de proyecciones + depósito } \\
\text { Salón de ensayo } \\
\text { Cubículo de práctica grupal } \\
\text { Cubículo de práctica individual } \\
\text { Guardaropa } \\
\text { Hall Auditorio } \\
\text { Foyer }\end{array}$ \\
\hline
\end{tabular}


Tabla 27: Tabla de paquete funciona, Zonas públicas / Elaboración propia

\begin{tabular}{|l|c|}
\hline & Hall ingreso general + informes \\
ZONAS PÚBLICAS & SSHH Hall \\
& Área exposición trabajos \\
& Boulevard cultural \\
Estacionamientos
\end{tabular}


7.2. Programa arquitectónico 


\subsection{Cuadro de compatibilidad}

\section{POR PAQUETES FUNCIONALES}
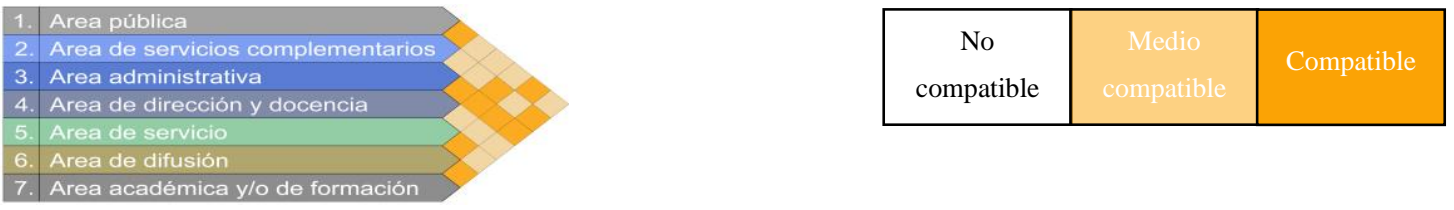

Fig. 22: Cuadro de compatibilidad por paquetes funcionales / Elaboración propia

\section{POR AMBIENTES}
1. Estacionamiento
2. Plaza o Atrio
3. Anfiteatro
4. Hall de ingreso general
5. Aulas teóricas
6. Estudios de danza
7. Estudios de Teatro
8. Estudios de Música
9. Talleres Escenográficos
10. Talleres de Teatro
11. Teatro experimental
12. Servicios Higiénicos
13. Vestidores
14. Atención física
15. Salas de representación
16. Cubículos de estudio
17. Laboratorios
18. Cabinas de grabación
19. Biblioteca
20. Gimnasio
21. Comedor-Restaurante
22. Departamento de Danza
23. Departamento de Música
24. Departamento de Teatro
25. Area de decanos
26. Area de directores
27. Sala de reuniones
28. Oficinas administrativas
29. Zona de servicio
30. Zona para el personal de servicio
31. Servicio de artistas
32. Area de soporte
33. Servicio al público
34. Sala de espectáculos
35. Escenario
36. Backstage
37. Administración de teatro
38. Producción de Teatro
39. Servicio de Teatro

Fig. 23: Cuadro de compatibilidad por ambientes / Elaboración propia 


\subsection{Detalles de ambiente específicos}

\section{ESTUDIO DE ENSEÑANZA PERSONALIZADA}

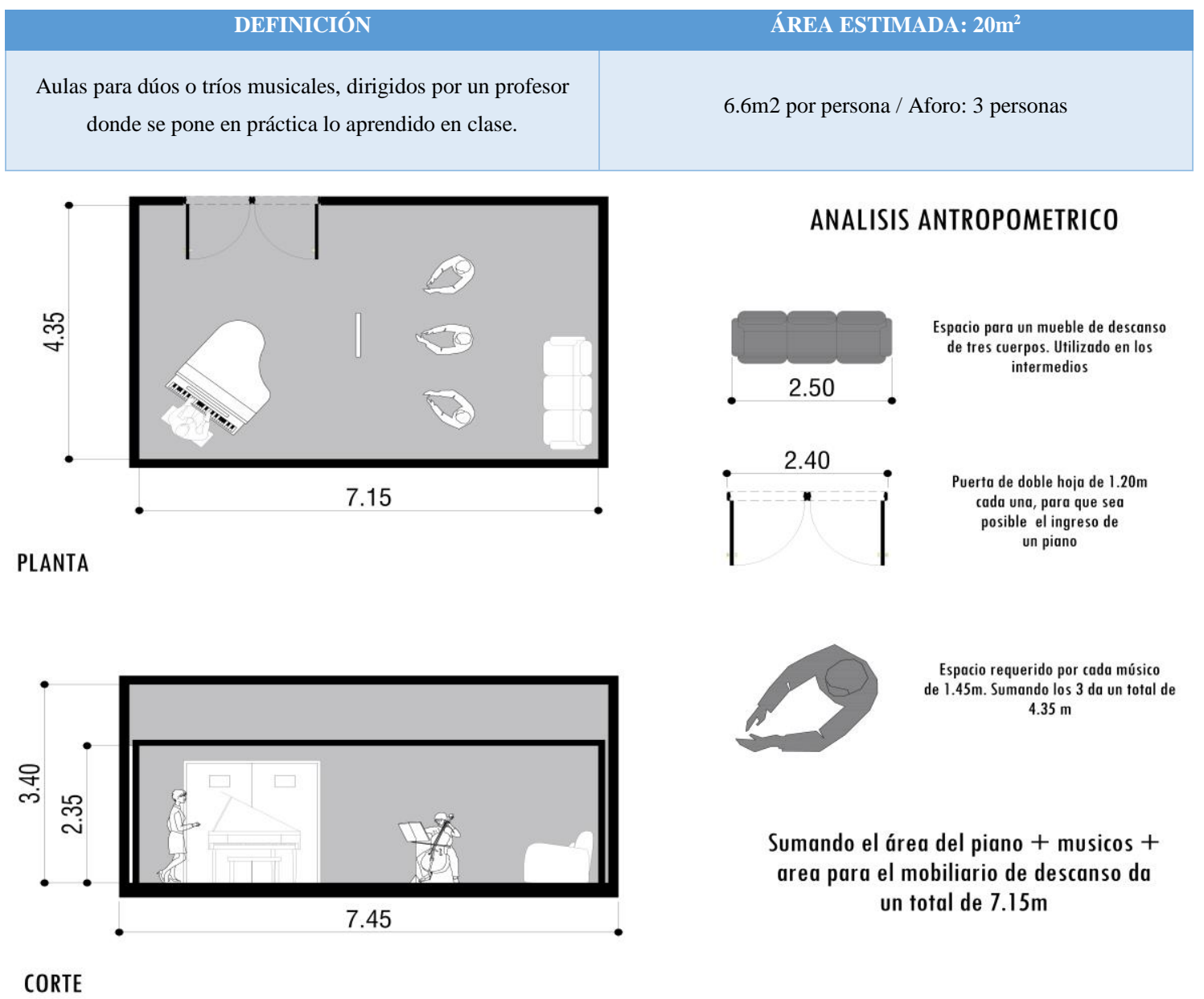

Fig.24: Planta Estudio de enseñanza personalizada

Fuente: Berrios (2005) (CIBERTESIS UPC) (ALVA ZEVALLOS)

\begin{tabular}{|c|c|c|}
\hline MOBILIARIO & ACUSTICA Y MATERIALES & ILUMINACIÓN Y VENTILACIÓN \\
\hline $\begin{array}{ll}\bullet & 4 \text { SILLAS } \\
\bullet & 4 \text { ATRILES } \\
\bullet & 1 \text { PIANO } \\
\bullet & \text { MUEBLES DE } \\
& \text { DESCANSO } \\
\bullet & 1 \text { DEPÓSITO DE } \\
& \text { INSTRUMENTOS }\end{array}$ & $\begin{array}{l}\text { ACÚSTICA: } 38 \mathrm{db} \text {. } \\
\text { MUROS: doble muro para aislamiento } \\
\text { acústico. } \\
\text { PUERTAS Y VENTANAS: puertas } \\
\text { acústicas con bordes protegidos y las } \\
\text { ventanas con cristal laminado incoloro } \\
\text { mínimo de } 8 \mathrm{~mm} \text {. } \\
\text { PISO: piso machihembrado de madera, } \\
\text { el cual funciona como elemento } \\
\text { absorbente de cuerda o de sonido } \\
\text { moderado. } \\
\text { TECHO: baldosas } \\
\text { suspendidas en el techo y paneles de } \\
\text { absorción en las paredes. }\end{array}$ & $\begin{array}{l}\text { ILUMINACION: } \\
\text { - Iluminación natural (vanos aislantes) } \\
\text { - Iluminación artificial (300 luxes) } \\
\text { VENTILACIÓN: } \\
\text { Ventilación artificial: Sistema de aire } \\
\text { acondicionado y recirculación de aire } \\
\text { independientes para evitar el ingreso de } \\
\text { ruido. }\end{array}$ \\
\hline
\end{tabular}




\section{SALA DE ENSAMBLE}

\begin{tabular}{|c|c|}
\hline \multicolumn{1}{|c|}{ DEFINICIÓN } & ÁREA ESTIMADA: $35 \mathrm{~m}^{2}$ \\
\hline Estos espacios son para el ensayo de pequeños grupos de & \\
músicos y debe contar con espacios para un piano y el resto de & $7 \mathrm{~m} 2$ por persona / Aforo: 5 personas \\
\hline los instrumentos. & \\
\hline
\end{tabular}
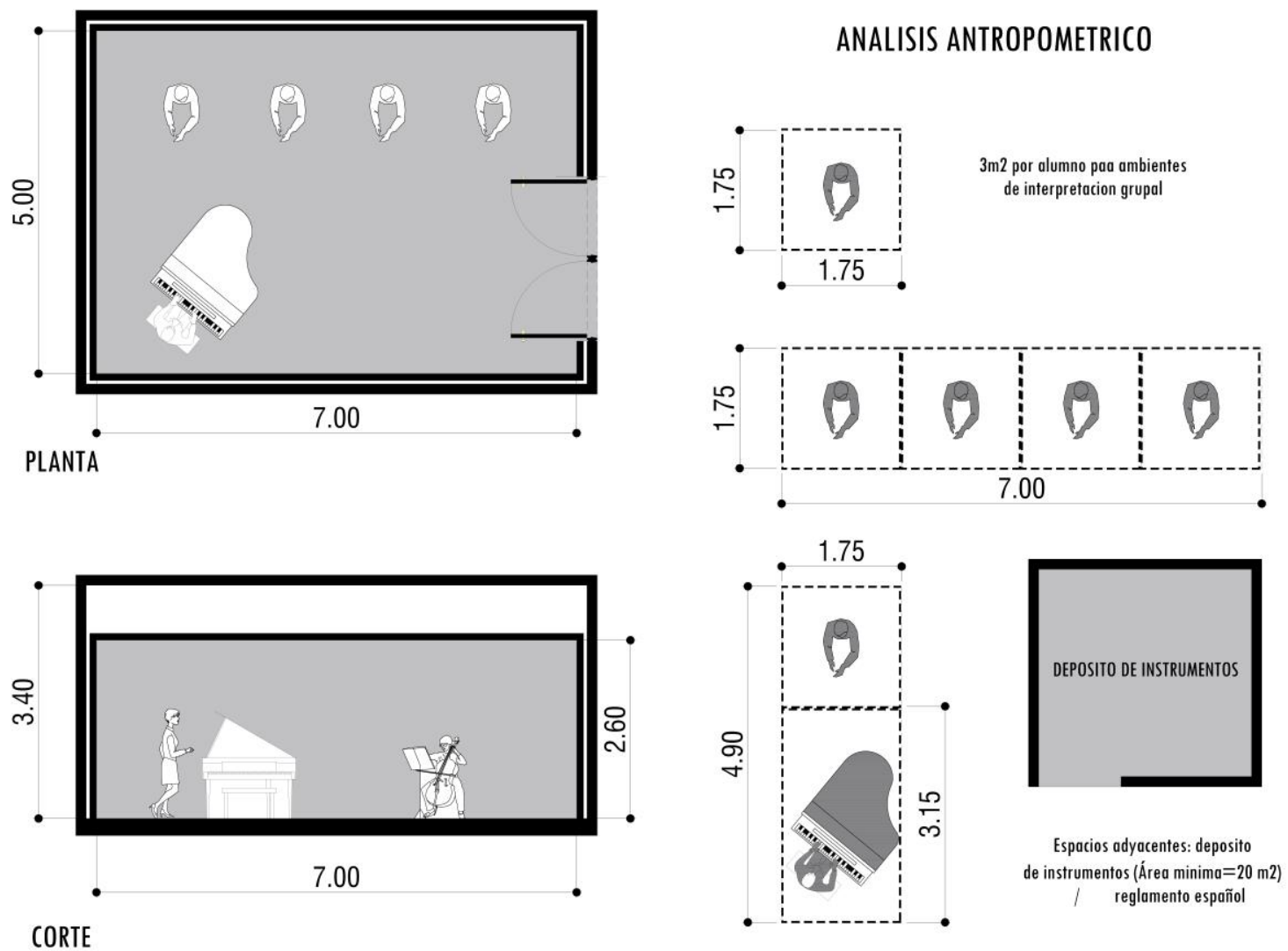

Fig. 25: Planta Sala de Ensamble

Fuente: Berrios (2005) (CIBERTESIS UPC) (ALVA ZEVALLOS)

\begin{tabular}{|c|c|c|}
\hline MOBILIARIO & ACUSTICA Y MATERIALES & ILUMINACIÓN Y VENTILACIÓN \\
\hline $\begin{array}{ll}\bullet & 5 \text { SILLAS } \\
\bullet & 5 \text { ATRILES } \\
\bullet & 1 \text { PIANO } \\
\bullet & \text { MUEBLES DE } \\
& \text { DESCANSO } \\
\text { - } & 1 \text { DEPÓSITO DE } \\
& \text { INSTRUMENTOS } \\
\bullet & \text { EQUIPOS DE } \\
& \text { AUDIO Y VIDEO }\end{array}$ & $\begin{array}{l}\text { ACÚSTICA: } 38 \mathrm{db} \text {. } \\
\text { MUROS: doble muro para aislamiento } \\
\text { acústico y paneles de absorción entre } \\
\text { muros. } \\
\text { PISO: piso machihembrado de madera, } \\
\text { el cual funciona como elemento } \\
\text { absorbente de cuerda o de sonido } \\
\text { moderado. } \\
\text { TECHO: } \\
\text { suspendidas en el techo y paneles de } \\
\text { absorción en las paredes. }\end{array}$ & $\begin{array}{l}\text { ILUMINACION: } \\
\text { Debe ser iluminado artificialmente ya } \\
\text { que este es un recinto aislado } \\
\text { acústicamente. Iluminación artificial } \\
\text { (300 luxes) } \\
\text { VENTILACIÓN: } \\
\text { Ventilación artificial: Sistema de aire } \\
\text { acondicionado y recirculación de aire } \\
\text { independientes para evitar el ingreso de } \\
\text { ruido. }\end{array}$ \\
\hline
\end{tabular}




\section{SALA PRACTICA CORAL}

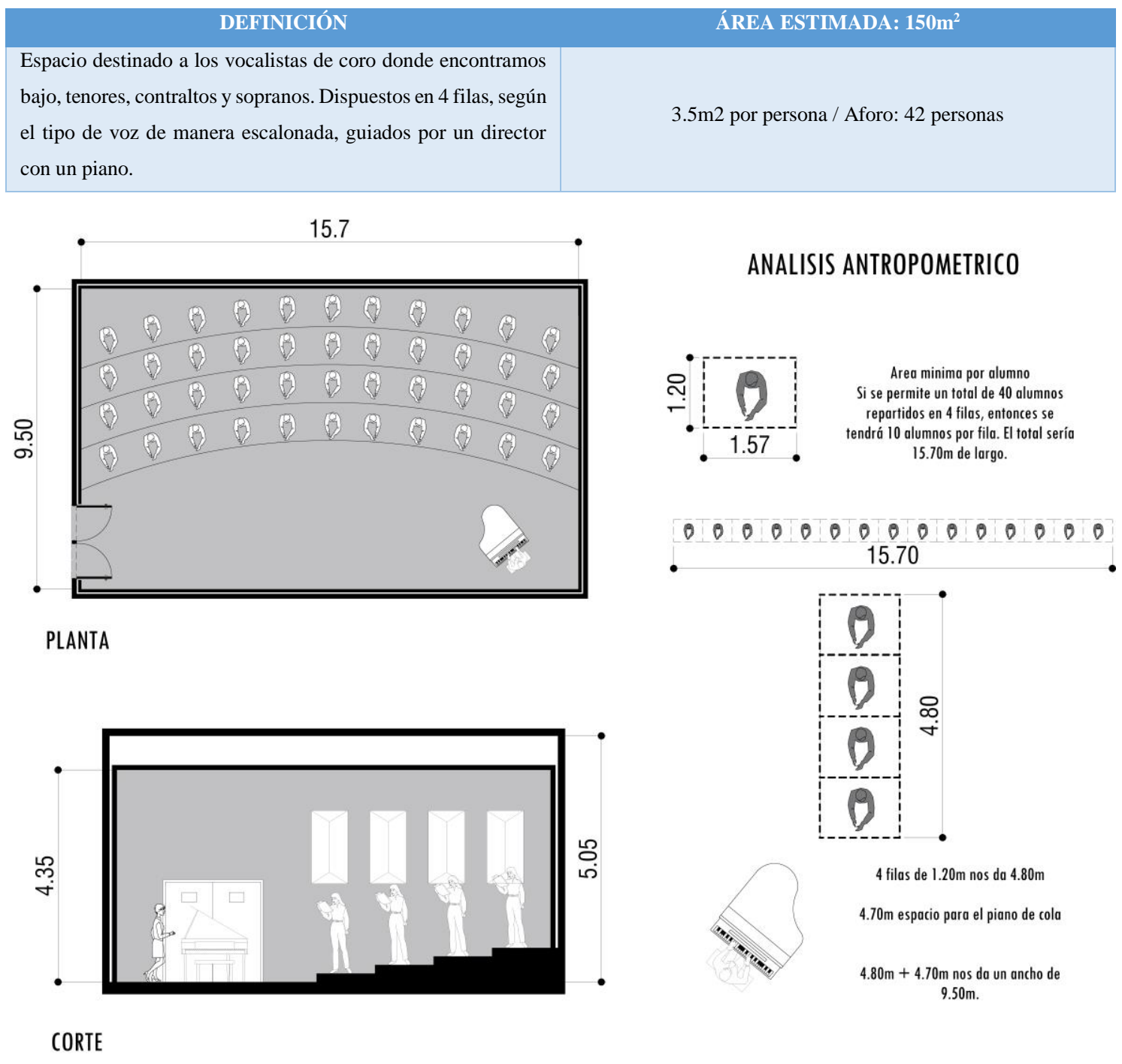

Fig. 26: Planta de Sala de Práctica Coral

Fuente: Berrios (2005) (CIBERTESIS UPC) (ALVA ZEVALLOS)

ACÚSTICA: $38 \mathrm{db}$.

MUROS: doble muro para aislamiento acústico y paneles de absorción entre muros. Se debe evitar las paredes paralelas para que el sonido no revote. PISO: piso machihembrado de madera el cual funciona como elemento absorbente de cuerda o de sonido moderado.

TECHO: baldosas acústicas suspendidas en el techo y paneles de absorción en las paredes.

\section{ILUMINACION:}

Debe ser iluminado artificialmente ya que este es un recinto aislado acústicamente. Iluminación artificial (300 luxes)

\section{VENTILACIÓN:}

Ventilación artificial: Sistema de aire acondicionado y recirculación de aire independientes para evitar el ingreso de ruido. 


\section{SALA PRÁCTICA DE ORQUESTAS Y/O BANDAS}

\begin{tabular}{|c|c|}
\hline DEFINICIÓN & ÁREA ESTIMADA: 150m² \\
\hline $\begin{array}{c}\text { Es aquí donde los músicos pueden ensayar como conjunto, } \\
\text { incluyendo una pequeña orquesta (octeto) con coros o una } \\
\text { banda. }\end{array}$ & $5 \mathrm{~m} 2$ por persona / Aforo: 3 personas \\
\hline
\end{tabular}
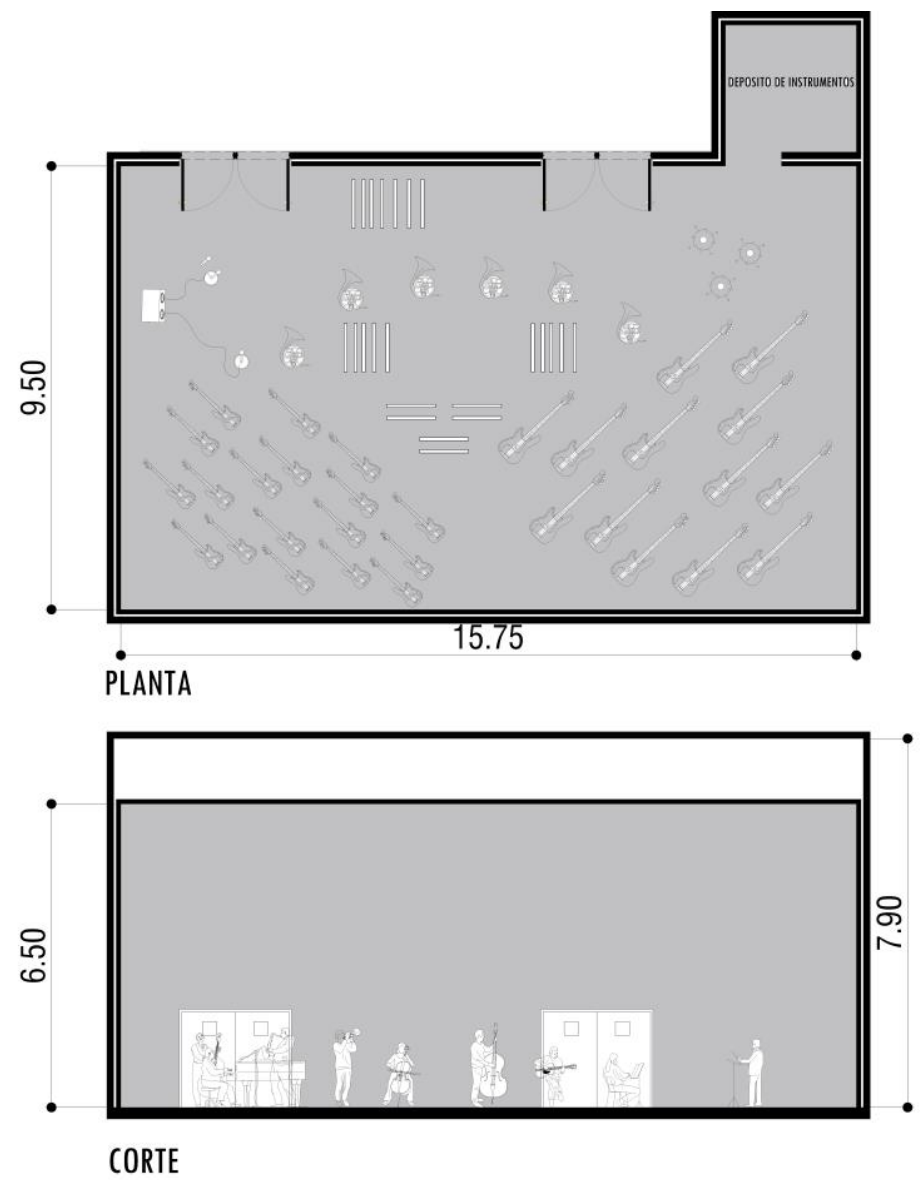

Fig. 27: Sala de Práctica de Orquestas y/o Bandas

Fuente: Berrios (2005) (CIBERTESIS UPC) (ALVA ZEVALLOS)

\section{ANALISIS ANTROPOMETRICO}

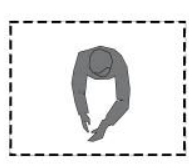

AREA MINIMA $=150 \mathrm{M}$ Para un total de 50 alumnos +1 director $y$ un pianista.

AREA POR ALUMNO $=3 M 2$

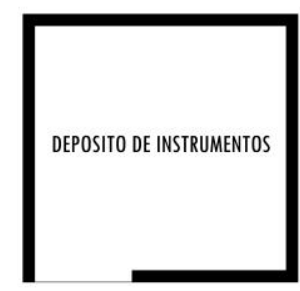

Espacios adyacentes: deposito de instrumentos (Área minima $=20 \mathrm{~m} 2$ ) reglamento español

AREA NECESARIA PARA LA CANTIDAD DE INSTRUMENTOS 40 M2

\begin{tabular}{|c|c|c|}
\hline MOBLLARIO & ACUSTICA Y MATERIALES & ILUMINACIÓN Y VENTILACIÓN \\
\hline $\begin{array}{ll}\bullet & 50 \text { SILLAS } \\
\bullet & 50 \text { ATRILES } \\
\bullet & 1 \text { PIANO } \\
\bullet & \text { MUEBLES DE } \\
& \text { DESCANSO } \\
\bullet & 1 \text { DEPÓSITO DE } \\
\text { INSTRUMENTOS }\end{array}$ & $\begin{array}{l}\text { ACÚSTICA: } 38 \mathrm{db} \text {. } \\
\text { MUROS: doble muro para aislamiento } \\
\text { acústico y paneles de absorción entre } \\
\text { muros. } \\
\text { PISO: piso machihembrado de madera, } \\
\text { el cual funciona como elemento } \\
\text { absorbente de cuerda o de sonido } \\
\text { moderado. } \\
\text { TECHO: } \\
\text { suspendidas en el techo y paneles de } \\
\text { absorción en las paredes. }\end{array}$ & $\begin{array}{l}\text { ILUMINACION: } \\
\text { Debe ser iluminado artificialmente ya } \\
\text { que este es un recinto aislado } \\
\text { acústicamente. Iluminación artificial } \\
\text { (300 luxes) } \\
\text { VENTILACIÓN: } \\
\text { Ventilación artificial: Sistema de aire } \\
\text { acondicionado y recirculación de aire } \\
\text { independientes para evitar el ingreso de } \\
\text { ruido. }\end{array}$ \\
\hline
\end{tabular}




\section{AULAS TEÓRICAS}

\begin{tabular}{|c|c}
\hline \multicolumn{1}{|c|}{ DEFINICIÓN } & ÁREA ESTIMADA: 42 $\mathbf{m}^{2}$ \\
\hline Lugar donde se realizan clases teóricas. & $2.1 \mathrm{~m} 2$ por persona / Aforo: 20 personas \\
\hline
\end{tabular}

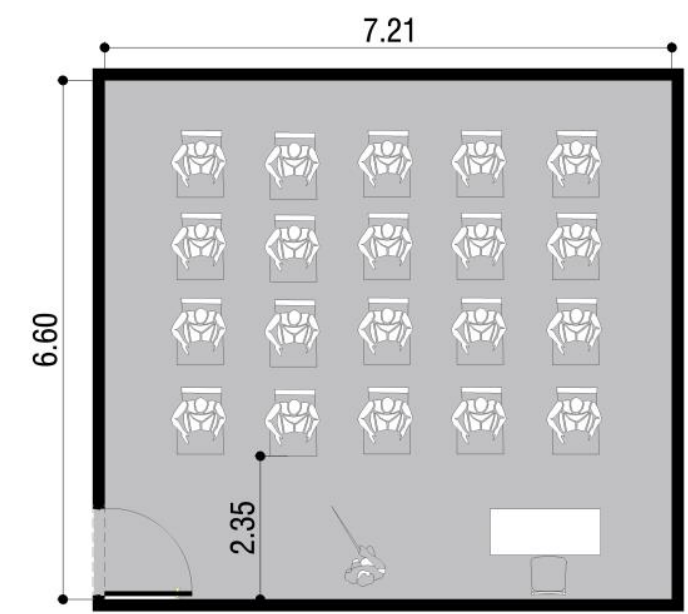

PLANTA

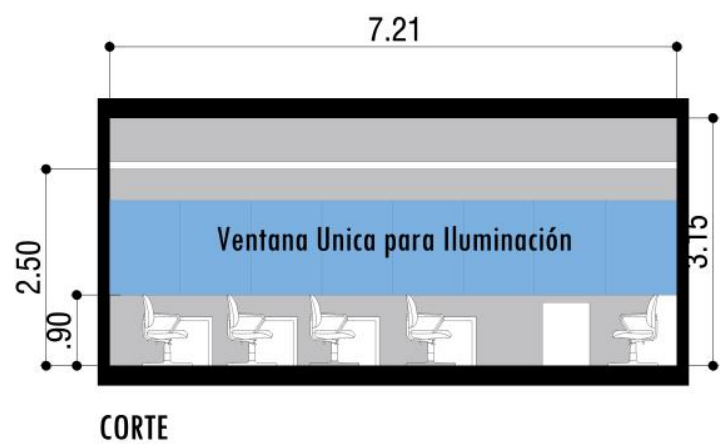

Fig. 28: Planta de Aulas Teóricas

Fuente: Berrios (2005) (CIBERTESIS UPC) (ALVA ZEVALLOS)

\section{ANALISIS ANTROPOMETRICO}

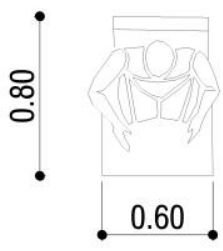

Area minima para alumno $=0.51 \mathrm{~m} 2$ Separación entre carpetas $0.60 \mathrm{~m}$

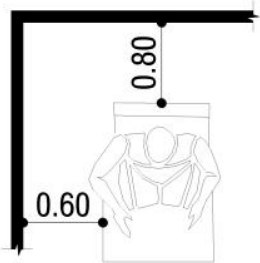<smiles>C1C[Te]C1</smiles>

Ancho mínimo de la puerta $1.20 \mathrm{~m}$

Altura de piso a carpeta: $0.75 \mathrm{~m}$ Altura de piso a asiento: $0.55 \mathrm{~m}$

\section{MOBILIARIO}

20 CARPETAS UNIPERSONALES

- 1 ESCRITORIO

- 21 SILLAS

- 1 PIZARRA

- 1 TELEVISOR

- 1 RADIO

- $\quad$ EQUIPO DE AUDIO Y VIDEO

\section{ACUSTICA Y MATERIALES} ACÚSTICA: $38 \mathrm{db}$.

MUROS: acabados en pintura con color claro.

PISO: piso machihembrado de madera,

el cual funciona como elemento absorbente de cuerda o de sonido moderado.

TECHO: baldosas acústicas suspendidas en el techo y paneles de absorción en las paredes.

\section{ILUMINACIÓN Y VENTILACIÓN}

\section{ILUMINACION:}

Iluminación natural $20 \%$ del área total del recinto.

Iluminación artificial 250 luxes.

\section{VENTILACIÓN:}

Ventilación artificial: permanente, alta y cruzada. El volumen de aire requerido por alumno será de $4.5 \mathrm{~m}^{2}$. 


\section{ESTUDIO DE DANZA GRANDE}

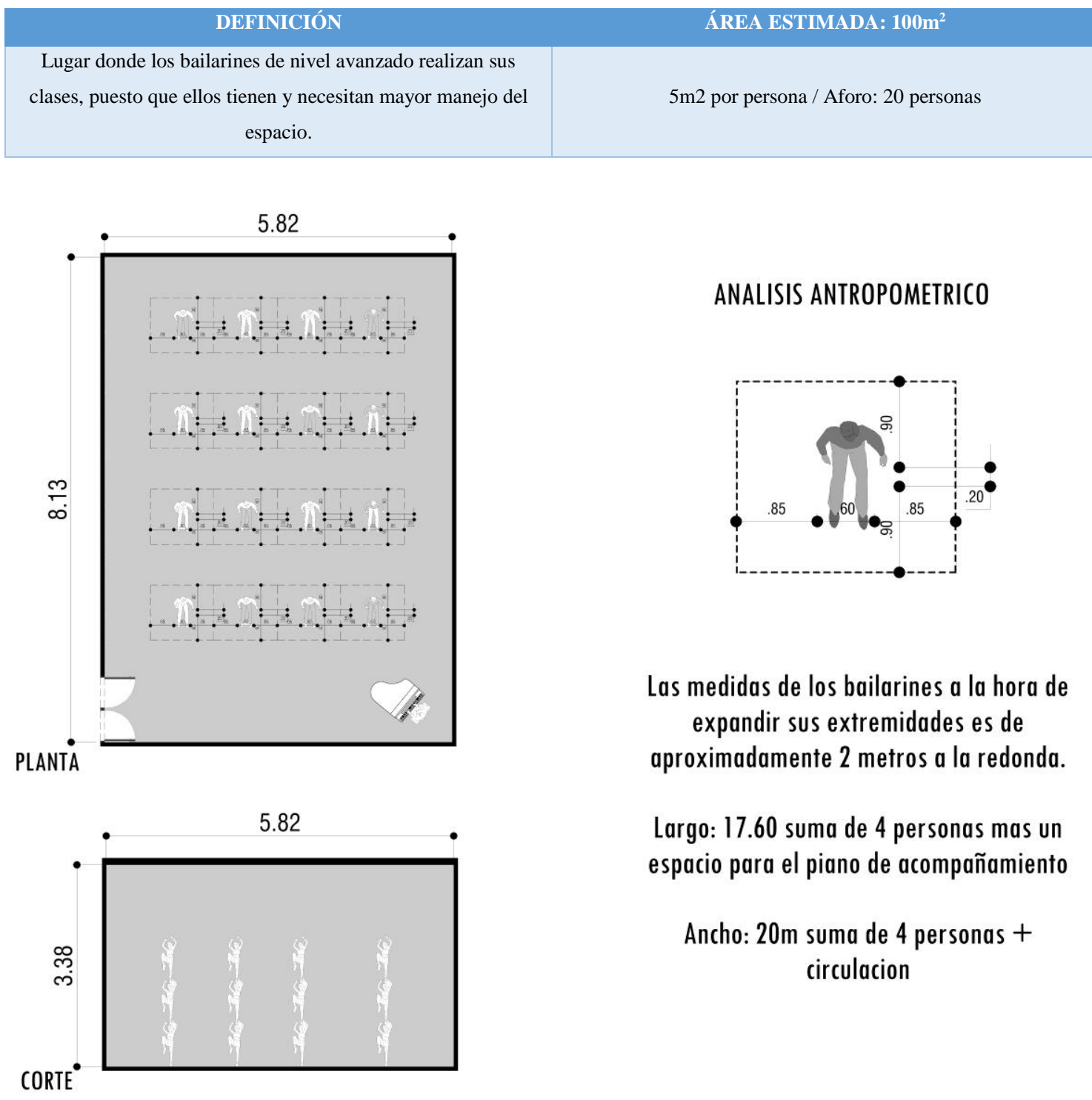

Fig. 29: Planta de Estudio de Danza Grande

Fuente: Berrios (2005) (CIBERTESIS UPC) (ALVA ZEVALLOS)

\begin{tabular}{|c|c|c|}
\hline MOBILIARIO & ACUSTICA Y MATERIALES & ILUMINACIÓN Y VENTILACIÓN \\
\hline $\begin{array}{ll}\text { - } & 1 \text { EQUIPO DE } \\
& \text { SONIDO } \\
\bullet & \text { ESPEJOS } \\
\bullet & \text { ESTANTES } \\
\bullet & \text { PROYECTOR } \\
\bullet & \text { BARRAS DE } \\
& \text { BALLET } \\
\bullet & \text { COLCHONETAS } \\
\bullet & 1 \text { DEPOSITO }\end{array}$ & $\begin{array}{l}\text { ACÚSTICA: } 38 \mathrm{db} \text {. } \\
\text { VANOS: puertas aislantes. } \\
\text { PANELES: absorbentes. } \\
\text { MATERIALES: pisos flexibles } \\
\text { (flotantes) machihembrado de madera } \\
\text { suspendido sobre durmientes. Se cubre } \\
\text { con un material antideslizante como es el } \\
\text { caso de linóleum. } \\
\text { CALEFACCION PARA } \\
\text { MANTENIMIENTO DE ESPEJO Y } \\
\text { BARRAS }\end{array}$ & $\begin{array}{l}\text { ILUMINACION: } \\
\text {-Iluminación natural: se debe ubicar con } \\
\text { orientación norte-sur. } \\
\text {-Iluminación artificial: Lámparas } \\
\text { fluorescentes colgantes lineales. } \\
\text { VENTILACIÓN: } \\
\text { Ventilación natural que permitan el buen } \\
\text { desarrollo de las actividades de baile, no } \\
\text { deben poseer sistema de aire } \\
\text { acondicionado por razones de salud, pero } \\
\text { si un sistema de extracción. }\end{array}$ \\
\hline
\end{tabular}




\section{TALLER DE MAQUILLAJE}

\section{DEFINICIÓN}

Recinto donde se dictan clases teóricas y prácticas de maquillaje artístico teatral,

\section{ÁREA ESTIMADA: $152 \mathrm{~m}^{2}$}

$4.3 \mathrm{~m} 2$ por persona / Aforo: 35 personas

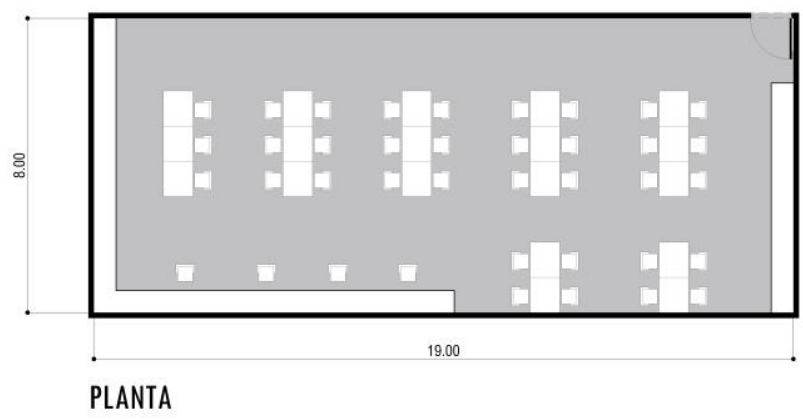

PLANTA

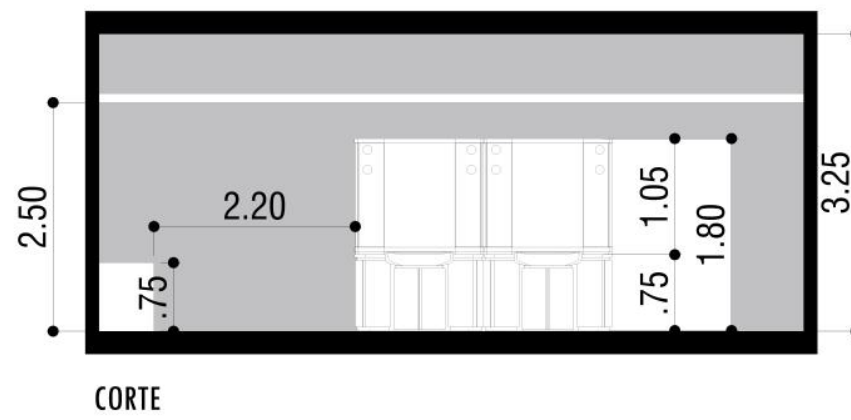

Fig. 30: Planta de Taller de Maquillaje
ANALISIS ANTROPOMETRICO

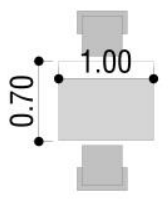

Dimensiones minimas

para un equipo de

tocador $=1.00 \mathrm{~m} \times 0.70 \mathrm{~m}$

Espacio de circulación

entre carpetas $=1.20 \mathrm{~m}$

Ancho total de $8.00 \mathrm{~m}$

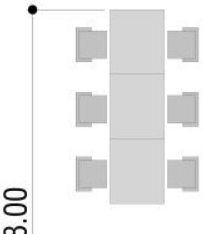

Ancho de tocador pegado a la pared $.65 \mathrm{~m}$

Fuente: Berrios (2005) (CIBERTESIS UPC) (ALVA ZEVALLOS)

- MESAS TIPO

TOCADOR

- ESPEJOS

- SILLAS

- COMPUTADORA

- PROYECTOR

- PARLANTES

- DEPOSITOS

- ESTANTES
ACÚSTICA: $38 \mathrm{db}$.

MUROS: acabados en pintura color claro.

TECHO: baldosas acústicas suspendidas en el techo y paneles de absorción en las paredes.

\section{ILUMINACIÓN Y VENTILACIÓN}

\section{ILUMINACION:}

Iluminación natural 20\% del área total del recinto.

Iluminación artificial 250 luxes.

\section{VENTILACIÓN:}

Ventilación natural: permanente, alta y cruzada. El volumen de aire requerido por alumno será de $4.5 \mathrm{~m}^{2}$. 


\section{TEATRO - TALLER DE INTERPRETACIÓN}

\begin{tabular}{|c|c|}
\hline \multicolumn{1}{|c|}{ DEFINICIÓN } & ÁREA ESTIMADA: 20m² \\
\hline $\begin{array}{c}\text { Aulas para dúos o tríos, dirigidos por un profesor donde se } \\
\text { pone en práctica lo aprendido en clase. }\end{array}$ & $6.6 \mathrm{~m} 2$ por persona / Aforo: 3 personas \\
\hline
\end{tabular}
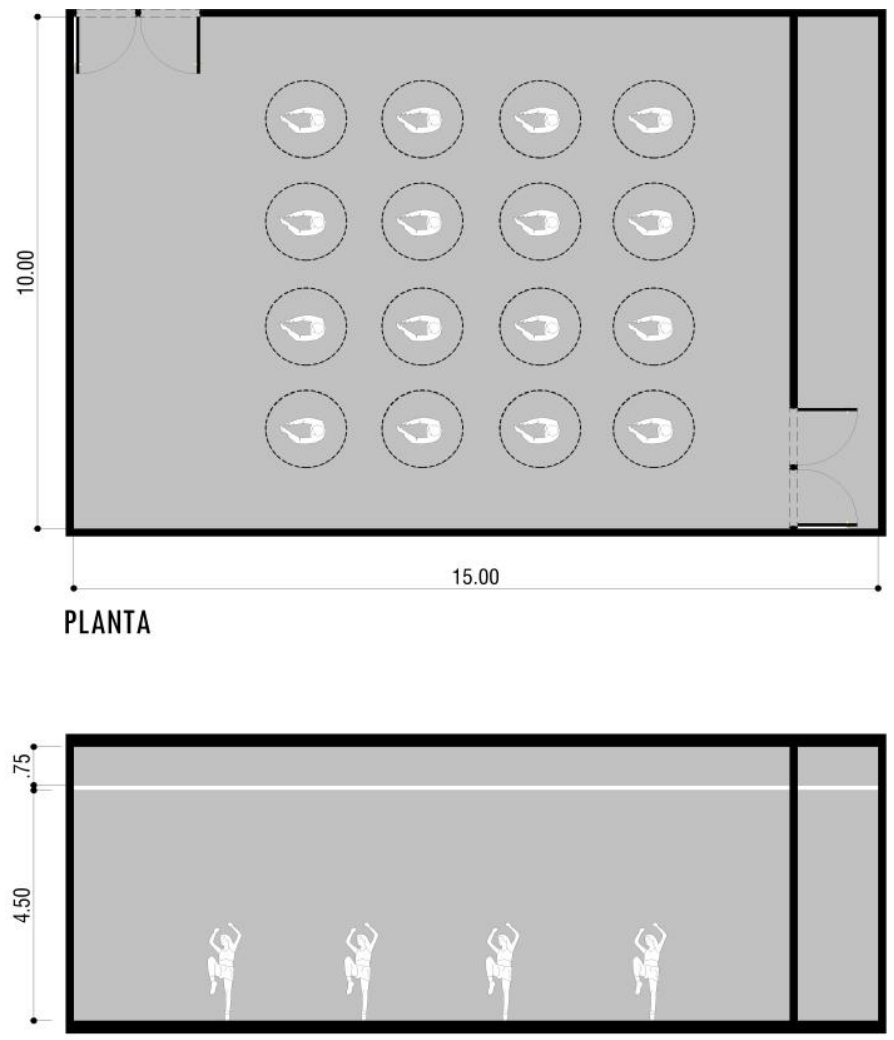

CORTE
ANALISIS ANTROPOMETRICO

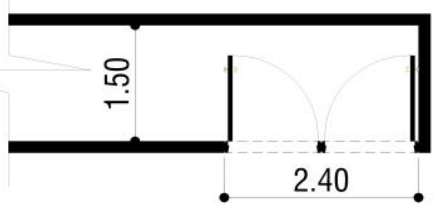

Depósito ancho mínimo de $1.50 \mathrm{~m}$ y puerta de doble hoja $1.20 \mathrm{~m} \mathrm{c} / \mathrm{u}$

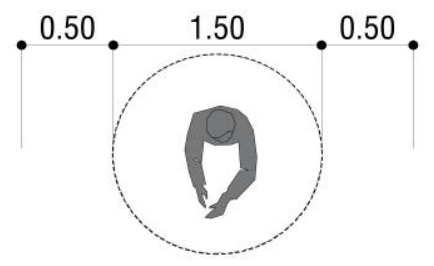

Area de desplazamiento por alumno optima es de 1.50 de diametro $+0.50 \mathrm{~m}$ de separacion entre alumnos

Ilustración 31: Planta de Taller de Interpretación

Fuente: Berrios (2005) (CIBERTESIS UPC) (ALVA ZEVALLOS)

\section{MOBILIARIO}

\begin{tabular}{|c|c|}
\hline MOBILIARIO & ACUSTICA Y MATERIALES \\
\hline $\begin{array}{ll}\bullet & 4 \text { SILLAS } \\
\bullet & 4 \text { ATRILES } \\
\bullet & 1 \text { PIANO } \\
\bullet & \text { MUEBLES DE } \\
& \text { DESCANZO } \\
\bullet & 1 \text { DEPOSITO DE } \\
& \text { INSTRUMENTOS }\end{array}$ & $\begin{array}{l}\text { ACÚSTICA: } 38 \mathrm{db} \text {. } \\
\text { MUROS: doble muro para aislamiento } \\
\text { acústico. } \\
\text { PUERTAS Y VENTANAS: puertas } \\
\text { acústicas con bordes protegidos y las } \\
\text { ventanas con cristal laminado incoloro } \\
\text { mínimo } 8 \mathrm{~mm} \text {. } \\
\text { PISO: piso machihembrado de madera, } \\
\text { el cual funciona como elemento } \\
\text { absorbente de cuerda o de sonido } \\
\text { moderado. } \\
\text { TECHO: baldosas } \\
\text { suspendidas en el techo y paneles de } \\
\text { absorción en las paredes. }\end{array}$ \\
\hline
\end{tabular}

ILUMINACIÓN Y VENTILACIÓN

\section{ILUMINACION:}

-Iluminación natural (vanos aislantes)

-Iluminación artificial (300 luxes)

\section{VENTILACIÓN:}

Ventilación artificial: Sistema de aire acondicionado y recirculación de aire independientes para evitar el ingreso de ruido. 


\section{AUDITORIO - SALA DE ESPECTÁCULOS Y ESCENARIO}

\begin{tabular}{|c|c|}
\hline DEFINICIÓN & ÁREA ESTIMADA \\
\hline $\begin{array}{c}\text { Espacios dedicados al espectador y para que este presencie la } \\
\text { obra teatral. Espacio donde los artistas realizan la presentación } \\
\text { en vivo. }\end{array}$ & $\begin{array}{c}1200 \mathbf{~ m}^{2}-0.85 \mathrm{~m} 2 \text { por persona / Aforo: } 400 \text { personas } \\
\mathbf{4 5 0} \mathbf{~ m}^{\mathbf{2}}-30 \mathrm{~m} 2 \text { por persona / Aforo: } 15 \text { personas }\end{array}$ \\
\hline
\end{tabular}
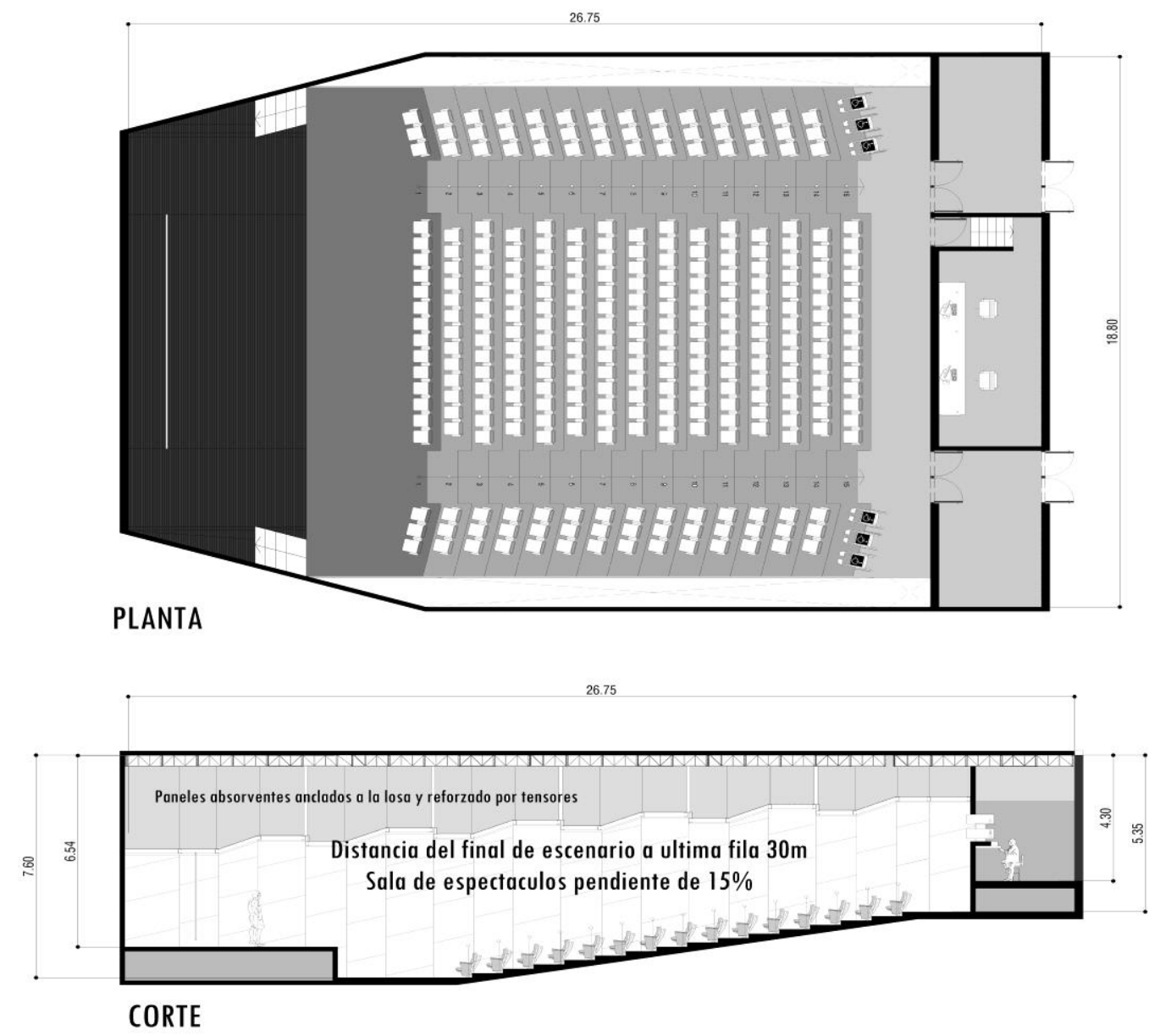

Fig. 32: Planta del Auditorio

Fuente: Berrios (2005) (CIBERTESIS UPC) (ALVA ZEVALLOS)

\begin{tabular}{|c|c|c|}
\hline MOBILIARIO & ACUSTICA Y MATERIALES & ILUMINACIÓN Y VENTILACIÓN \\
\hline - $\quad 400$ butacas & $\begin{array}{l}\text { Aislamiento acústico del auditorio } \\
\text { mediante la estructura. Doble muro de } \\
\text { concreto e: } 0.25 \mathrm{~m} \text {. } \\
\text { Separación de } .15 \mathrm{~m} \text { entre paredes o con } \\
\text { un panel de absorción } \\
\text { Se requiere también cerraduras de sonido } \\
\text { en todas las puertas. }\end{array}$ & $\begin{array}{l}\text { ILUMINACION } \\
\text { Iluminación Artificial ( } 350 \text { luxes) Se } \\
\text { utiliza antes de que la función comienza, } \\
\text { luego la sala debe estar sin iluminación y } \\
\text { toda la atención se concentre en el } \\
\text { escenario durante el espectáculo. } \\
\text { VENTILACION: } \\
\text { Ventilación Artificial: Sistema de aire } \\
\text { acondicionado y recirculación de aire } \\
\text { independientes para evitar el ingreso de } \\
\text { ruido. }\end{array}$ \\
\hline
\end{tabular}




\section{AUDITORIO - SALA DE ESPECTÁCULOS Y ESCENARIO}

\section{DEIFINICIÓN}

Espacios dedicados al espectador y para que este presencie la

obra teatral. Espacio donde los artistas realizan la presentación

en vivo.

\section{ÁREA ESTIMADA}

$450 \mathbf{~ m}^{2}-30 \mathrm{~m} 2$ por persona / Aforo: 15 personas

\section{ANALISIS ANTROPOMETRICO}

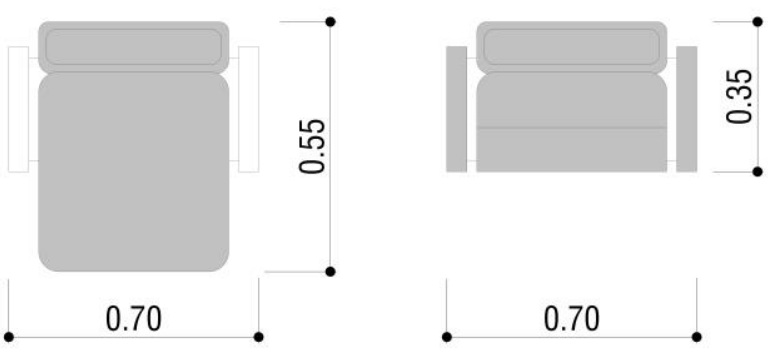

Ancho de butaca con apoyo para brazos

Butaca + espacio para circulación $1.20 \mathrm{~m}$

Gradería en filas y de ser posible los asientos intercalados en las filas para una mejor visual

Area en planta por persona $0.85 \mathrm{~m} 2$

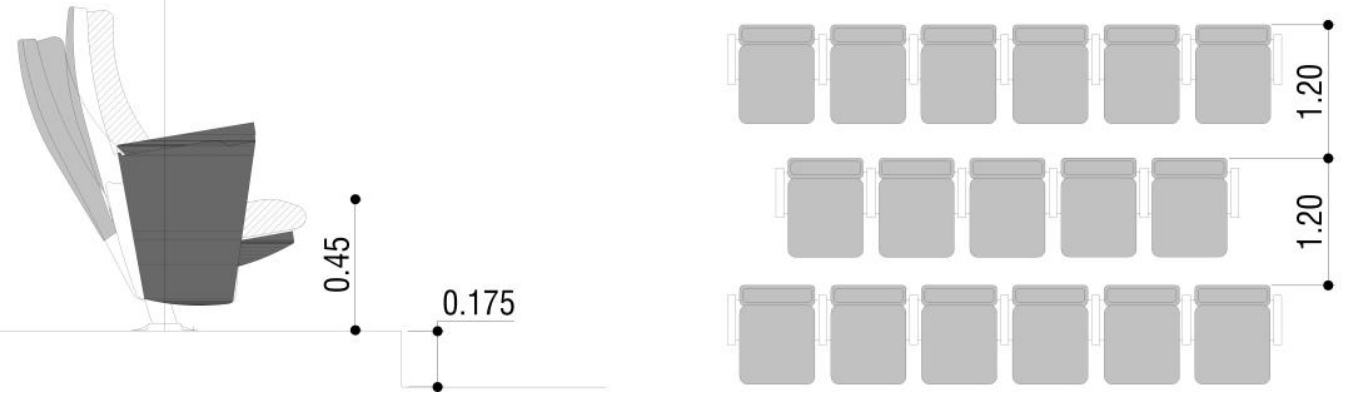

Fig. 33: Análisis antropométrico del auditorio

Fuente: Berrios (2005) (CIBERTESIS UPC) (ALVA ZEVALLOS)

\begin{tabular}{|c|c|c|}
\hline MOBILIARIO & ACUSTICA Y MATERIALES & ILUMINACIÓN Y VENTILACIÓN \\
\hline - $\quad 400$ BUTACAS & $\begin{array}{l}\text { Aislamiento acústico del auditorio } \\
\text { mediante la estructura. Doble muro de } \\
\text { concreto e: } 0.25 \mathrm{~m} \text {. } \\
\text { Separación de } .15 \mathrm{~m} \text { entre paredes o con } \\
\text { un panel de absorción } \\
\text { Se requiere también cerraduras de sonido } \\
\text { en todas las puertas }\end{array}$ & $\begin{array}{l}\text { ILUMINACION } \\
\text { Iluminación Artificial ( } 350 \text { luxes) Se } \\
\text { utiliza antes de que la función comienza, } \\
\text { luego la sala debe estar sin iluminación y } \\
\text { toda la atención se concentre en el } \\
\text { escenario durante el espectáculo. } \\
\text { VENTILACION: } \\
\text { Ventilación Artificial: Sistema de aire } \\
\text { acondicionado y recirculación de aire } \\
\text { independientes para evitar el ingreso de } \\
\text { ruido. }\end{array}$ \\
\hline
\end{tabular}


7.5. Criterios de diseño 


\section{CAPÍTULO VIII - Referencias}

Abad Carlés, A. (2004). Historia del ballet y de la danza moderna. Madrid: Alianza.

Adler, S. (s.f.). Academy of Acting and Theatre. Obtenido de http://www.stellaadler.la/

Alalú, J. (2017). Entrevista a la directora de estudios de TAE Perú. Lima, Lima, Perú.

Arau, H. (2007). ABC de la Arquitectura. CEAC.

Artes Escénicas. (s.f.). Obtenido de Ideas sobre interpretación: la Biomecánica de Meyerhold: https://arteescenicas.wordpress.com

Avitia Hernández, A. (2011). En Teatro para principiantes (pág. 63). México DF: Porrúa. Broyles-González, Y. (1994). El Teatro Campesino: Teatro en el Movimiento Chicano.

En Y. Broyles-González. University of Texas Press.

Carolina Merchan Price. (2014). Hablar y escribir sobre la obra: una problemática interdidáctica para la enseñanza artística y cultural. Education et Didactique.

Cava, J. G. (s.f.). Meisner Technique. Obtenido de http://www.meisner.es/

Consejo Nacional de la Cultura y las Artes, gobierno de Chile. (2012). Obtenido de http://www.estaciondelasartes.com/wp-content/uploads/2014/04/GlosarioTeatro.pdf

Convenio de Cooperación Interinstitucional: MINEDU-UNI-FAUA. (2006). Lima.

Cuore Panic. (s.f.). Obtenido de http://www.cuorepanico.com/

Departamento de Educación y Cultura ,Gobierno de Navarra. (s.f.). Obtenido de Departamento de Educación: https://www.educacion.navarra.es/documents/57308/57787/ARTESCENICAS.p df/72f9f067-4886-4813-9de5-4e6990da642a

Díaz, Juan José. (2006). Grupo de Análisis para el Desarrollo. Obtenido de Educación superior en el Perú: tendencias de la demanda y la oferta: http://www.grade.org.pe/

Diccionario de la Real Academia de La Lengua Española. (s.f.). Obtenido de http://dle.rae.es/

Durland, Steven. (1998). En Witness: The Guerrilla Theater of Greenpeace (págs. 6773).

El Comercio. (22 de Agosto de 2011). Lima Norte genera el 39\% de la actividad económica en la capital. Obtenido de http://www.elcomercio.pe/: 
http://elcomercio.pe/economia/peru/lima-norte-genera-39-actividad-economicacapital-noticia-1136523

El Comercio.pe. (05 de Mayo de 2010). Obtenido de http://elcomercio.pe/lima/sucesos/conozca-cuales-son-ventajas-desventajaslugares-mas-emblematicos-lima-noticia-472769

Escola Sant Gervasi, Cooperativa. (s.f.). Obtenido de Literatura, Los géneros Literales.: https://sites.google.com/a/xtec.cat/literadura-esg/apuntes-1/los-generos-teatrales

Estudio del Sector de las Artes Escénicas en Aragón. (2007). Obtenido de Escuela Universitario de Estudios Empresariales de Huesca / Universidad de Zaragoza: http://www.aragon.es/estaticos/ImportFiles/17/docs/Areas\%20generica/Publicac iones/Publicaciones\%20electr\%C3\%B3nicas/Cultura/ESTUDIO_ARTES_ESC ENICAS_ARAGON.pdf

Facultad de Artes Escénicas de la PUCP. (s.f.). Obtenido de http://facultad.pucp.edu.pe/artes-escenicas/

Favorini, A. (2012). Voicings: Ten Plays from the Documentary Theater. En A. Favorini. Ecco Press.

García, M. G. (1999). Akal.

Gómez García, M. (1997). En M. Gómez García, Diccionario del teatro (pág. 285). Madrid: Akal.

Grotowski, J. (1970). Hacia un teatro pobre. Siglo XXI.

Herman Hertzberger. (2005). Lessons for Students in Architecture. 010 Publishers.

Herman Hertzberger. (2010). Space and the Architect: Lessons in Architecture 2. 010 Publishers.

Infoartes. (2015). Fondo de ayudas para las artes escénicas IBERESCENA 2015-2016. Obtenido de Infoartes: http://www.infoartes.pe/estadisticas/

Juan Luis Orrego Penagos. (29 de Enero de 2010). Blog de Juan Luis Orrego. Obtenido de http://blog.pucp.edu.pe/blog/juanluisorrego/2010/01/29/notas-sobre-lahistoria-de-lima-norte-introduccion/

Kevin Lynch. (1998). La imagen de la ciudad. Gustavo Gili.

La acústica y la escena teatral/De la Grecia Clásica al Barroco. (s.f.). Obtenido de Universidad Politécnica de Madrid: http://ocw.upm.es/expresion-graficaarquitectonica/musica-y-arquitectura-espacios-y-paisajessonoros/contenidos/material-de-clase/t-4.pdf

La iluminación en la danza. (s.f.). Obtenido de ABC: http://www.abc.com.py/ 
Manuel Pérez Jiménez. (s.f.). Biblioteca Digital Universidad de Alcalá. Obtenido de Aproximación panorámica a la creación teatral actual: formas textuales y estilos escénicos: http://dspace.uah.es

Marcelle Michel, I. G. (1995). La danse au XXe siècle. París: Larousse.

Martín, R. C. (18 de Septiembre de 2012). red educativa musical. Obtenido de http://recursostic.educacion.es/artes/rem/web/index.php/es/musica-educacion-ytic/item/393-aprendizaje-colaborativo

Michels, U. (1985). Atlas de música. Alianza.

MINEDU. (2010). Artículo 19.- Institutos y Escuelas Superiores de Formación Artística . LIMA: MINEDU.

Ministerio de Cultura. (04 de Noviembre de 2015). Ministerio de Cultura. Obtenido de http://www.cultura.gob.pe/es/comunicacion/noticia/puntos-de-culturapromueven-arte-y-cultura-en-lima-norte-con-el-festival-mudate

Ministerio de Educacion de Argentina. (s.f.). Obtenido de Metodologia de enseñanzas de la musica: http//portal.edu.ar/debates/musica/puclivvion

National Michael Chekhov Association. (s.f.). Obtenido de http://www.michaelchekhov.net/

Neufert, E. (2013). Arte de proyecta en arquitectura. Barcelona: Gustavo Gili.

Nils Lennart Wallin, B. M. (2001). The Origins of Music. MIT Press.

Olivares, R. S. (2010). CADE 2010. Perú.

Osvaldo Pellettieri, 2. (2003). Historia del teatro argentino en Buenos Aires. Buenos Aires: Galerma.

Peter Brook. (1973). El espacio vacío: arte y técnica del teatro. Península.

Prof. Francisco Caro. (30 de marzo de 2015). Youtube. Obtenido de https://www.youtube.com/watch?v=WRqg2ORP3_0

Sevillano, A. B. (2013). Arquitectura Teatral, historia y acústica: El sonido de los Teatros. Andalucía: Centro de Documentación Musical de Andalucía.

Stanislavski, K. (1980). El trabajo del actor sobre sí mismo. Quetzal.

Sullivan, L. (1896). The Tall Office Building Artistically Considered. Lippincott's Magazine, $n^{\circ} 57$.

Ulrich, M. (2004). Atlas de la Música. Alianza.

Umberto Eco. (1970). La definición del arte. Barcelona: Martinez Roca.

UNESCO. (1982). Declaración de Mexico sobre las políticas culturales. Conferencia Mundial sobre las políticas culturales. Mexico DF. 
Vicente, T. G. (2016). Iluminación teatral. Obtenido de Red Teatral: http://www.redteatral.net/noticias-iluminaci-n-teatral-296 Yzusqui, J. (2010). CADE 2010. Perú. 